\title{
Enhancing quality and extending shelf life of rainbow trout (Oncorhynchus mykiss) by vitamin E supplementation and post- harvest antimicrobial intervention
}

\author{
Nalini Kamireddy \\ West Virginia University
}

Follow this and additional works at: https://researchrepository.wvu.edu/etd

\footnotetext{
Recommended Citation

Kamireddy, Nalini, "Enhancing quality and extending shelf life of rainbow trout (Oncorhynchus mykiss) by vitamin E supplementation and post-harvest antimicrobial intervention" (2003). Graduate Theses, Dissertations, and Problem Reports. 1795.

https://researchrepository.wvu.edu/etd/1795

This Thesis is protected by copyright and/or related rights. It has been brought to you by the The Research Repository @ WVU with permission from the rights-holder(s). You are free to use this Thesis in any way that is permitted by the copyright and related rights legislation that applies to your use. For other uses you must obtain permission from the rights-holder(s) directly, unless additional rights are indicated by a Creative Commons license in the record and/ or on the work itself. This Thesis has been accepted for inclusion in WVU Graduate Theses, Dissertations, and Problem Reports collection by an authorized administrator of The Research Repository @ WVU. For more information, please contact researchrepository@mail.wvu.edu.
} 


\title{
ENHANCING QUALITY AND EXTENDING SHELF LIFE \\ OF RAINBOW TROUT (Oncorhynchus mykiss) \\ BY VITAMIN E SUPPLEMENTATION \\ AND POST HARVEST ANTIMICROBIAL INTERVENTION
}

\author{
Nalini Kamireddy
}

Thesis submitted to the Davis College of Agriculture, Forestry, and Consumer Sciences At West Virginia University In partial fulfillment of the requirements for the degree of

\author{
Master of Science \\ in \\ Animal and Veterinary Sciences \\ P. Brett Kenney, PhD., Chair \\ June deGraft-Hanson, PhD. \\ Jacek Jaczynski, PhD.
}

Division of Animal and Veterinary Sciences

Morgantown, West Virginia

2003

Key words: rainbow trout, vitamin E, acidified sodium chlorite, storage stabilty 


\section{ABSTRACT \\ Enhancing Quality and Extending Shelf Life of \\ Rainbow Trout (oncorhynchus mykiss) by Vitamin E Supplementation \\ and Post Harvest Antimicrobial Intervention}

Nalini Kamireddy

Rainbow trout were fed a control $(191 \mathrm{mg} / \mathrm{kg}$ ) or the control diet supplemented with $5000 \mathrm{mg}$ a-tocopherol $/ \mathrm{kg}$. Fish were sampled at 2, 3, 4, 5, 7, and 9 weeks of feeding; at each week fillets were evaluated at 0,7 , and $14 \mathrm{~d}$. Supplementation increased fillet $\alpha$-tocopherol content, and TBARS value were not affected. A feeding by storage time interaction was observed for fat content, psychrotrophic counts, cook yield, and shear force. For antimicrobial intervention, fillets were not treated or were dipped in water, $50 \mathrm{ppm}$ ASC, and $1000 \mathrm{ppm}$ ASC for $30 \mathrm{~s}$. Fillets were stored at $1-2^{\circ} \mathrm{C}$ for 0,8 , and $15 \mathrm{~d}$. A treatment by storage time interaction was observed for psychrotrophic counts. Aerobic plate counts were not affected by intervention, but increased during storage. Moisture, fat, $\mathrm{pH}$, TBARS, fatty acid composition, TVBN, TMA, color, cook yield, and shear force were not affected by intervention. TBARS decreased during storage. Fatty acids were stable during storage. 


\section{ACKNOWLEDGEMENTS}

I would like to express my sincerest gratitude to my chairman Dr. P. Brett Kenney for his guidance, encouragement, and support throughout this study. I would like to thank my committee members, Dr. June deGraft-Hanson, and Dr. Jacek Jaczynski for their suggestions and constructive criticism. I am very thankful to Susan Slider and Rodney Kiser for their technical support and friendly nature. I specially thank Dr. Sitima Jittinandana for helping me with the statistical analysis for my thesis work. I thank all the faculty, staff, and graduate students of division of Animal and Veterinary Sciences.

I thank Cayce Warf and Mortem Blomso, Alcide Corporation for their cooperation and also for donating the antimicrobial agent. I would like to thank Fresh water Institute for conducting feeding trial for vitamin E study.

I would like to thank my husband, Nagaraj, parents, Hanumareddy and Leelavathi, sisters, brother-in-law, nephews, cousins, and friends for their love and encouragement. 


\section{TABLE OF CONTENTS}

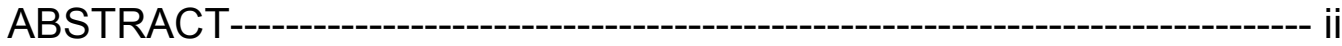

ACKNOWLEDGEMENTS--_-_-_-- ii

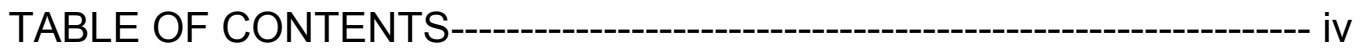

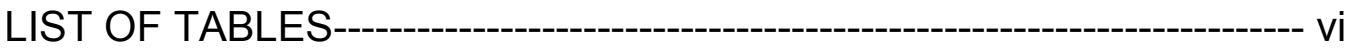

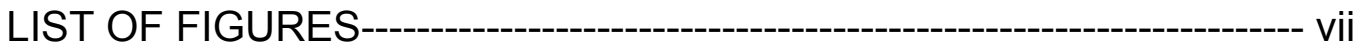

INTRODUCTION--1

LITERATURE REVIEW-_-_-_- 2

CHAPTER 1 Time and temperature affect storage stability of rainbow trout (Oncorhynchus mykiss) fillets
Abstract-
Introduction-
Materials and Methods
Results and Discussion

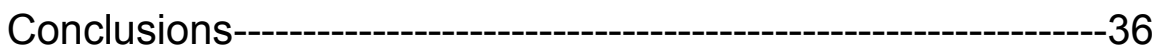

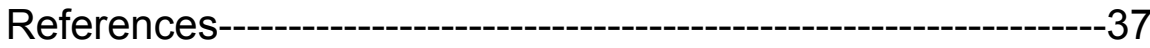

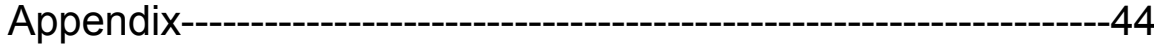

CHAPTER 2 Effect of vitamin E supplementation on storage stability of rainbow trout (Oncorhynchus mykiss) fillets

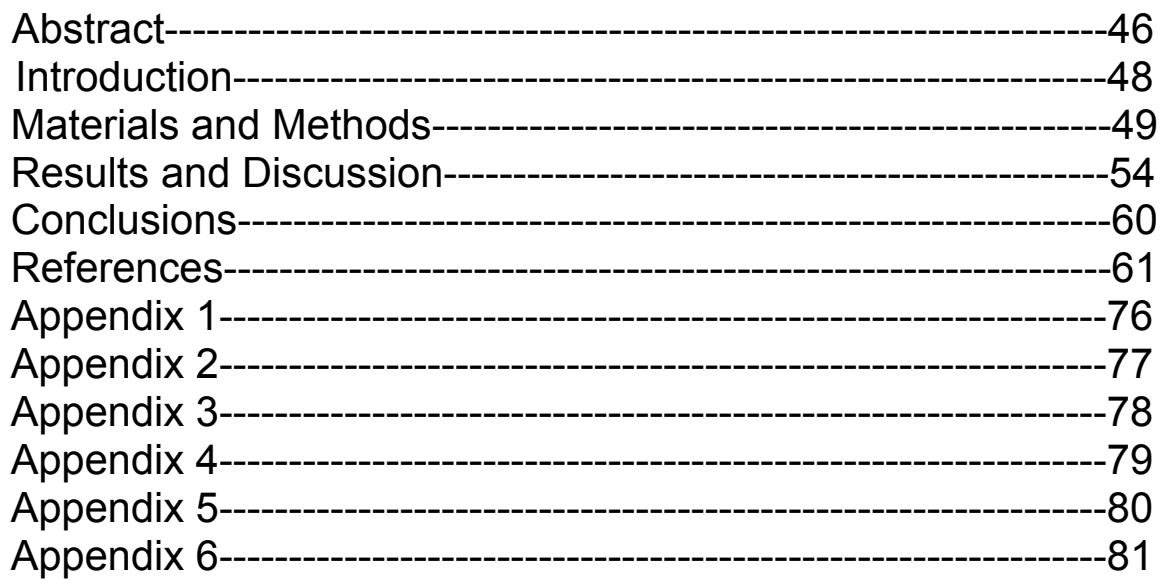


CHAPTER 3 Efficacy of acidified sodium chlorite in extending storage stability of rainbow trout (Oncorhynchus mykiss) fillets

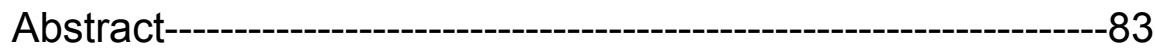

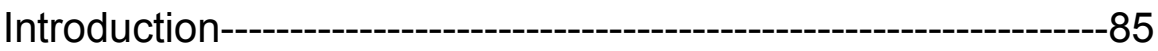

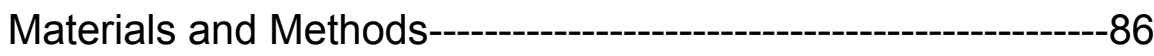

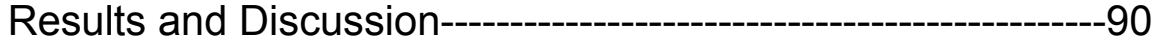

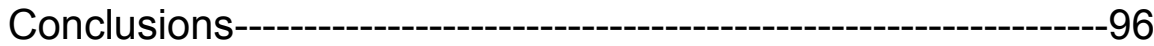

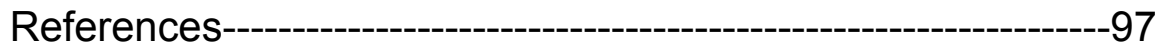

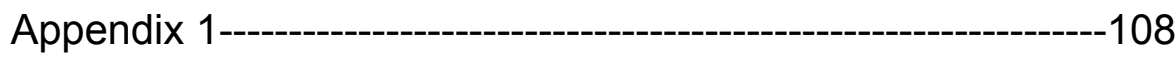

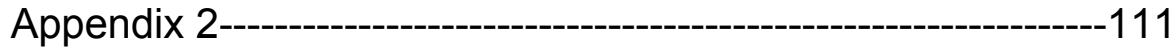

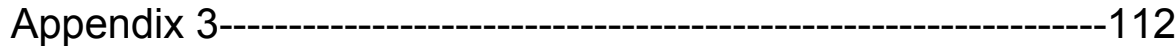

CURRICULUM VITAE--_-113 


\section{LIST OF TABLES}

\section{CHAPTER 1}

Table 1 Effect of storage temperature on muscle $\mathrm{pH}$, TBARS, $a^{*}$ value, $b^{*}$ value and shear force----on

Table 2 Effect of storage time on muscle $\mathrm{pH}$, TBARS, $a^{*}$ value, $b^{*}$ value, and shear force---

\section{CHAPTER 2}

Table 1 Effect of duration of feeding on weight gain---_-

Table 2 Effect of diet, duration of feeding, and storage time on a*value-----

Table 3 Effect of duration of feeding and storage time on

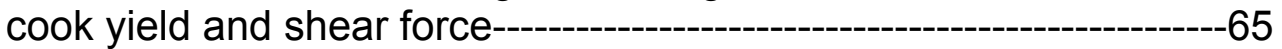

Table 4 Effect of diet, fasting, and storage time on psychrotrophic counts

Table 5 Effect of diet, duration of feeding, and storage time on moisture content-

Table 6 Effect of diet, fasting and storage time on moisture and fat Content

\section{CHAPTER 3}

Table 1 Effect of ASC treatment on muscle $\mathrm{pH}$, moisture, fat, TBARS, color, cook yield, and shear force of fillets

Table 2 Effect of ASC treatment on APC, TVBN, and TMA of fillets-----------101

Table 3 Changes in muscle $\mathrm{pH}$, moisture, fat, TBARS, color, cook yield,

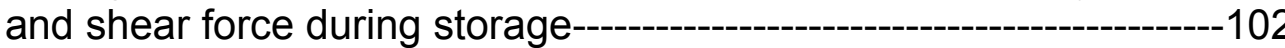

Table 4 Changes in APC, TVBN, and TMA of fillets during storage-----------103

Table 5 Effect of ASC on percent fatty acid content of fillets-------------------104

Table 6 Changes in percent fatty acid content during storage------------------105 


\section{LIST OF FIGURES}

\section{CHAPTER 1}

Figure 1 Effect of storage time and temperature on psychrotrophic counts-------41

Figure 2 Effect of storage time and temperature on $L^{*}$ value-----------------------42

\section{CHAPTER 2}

Figure 1 Effect of diet and duration of feeding on vitamin E content----------------69

Figure 2 Effect of diet, duration of feeding and storage time on TBARS----

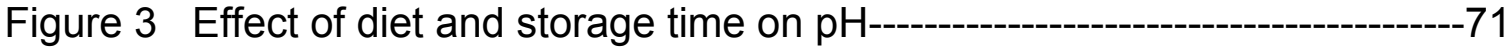

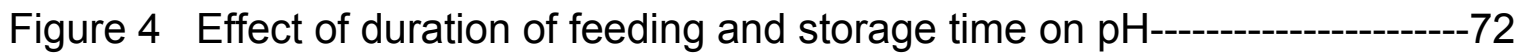

Figure 5 Effect of duration of feeding and storage time on

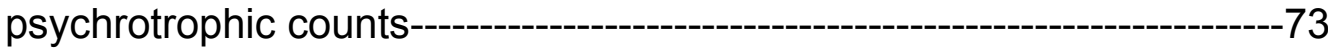

Figure 6 Effect of duration of feeding and storage time on fat content-------------74

\section{CHAPTER 3}

Figure 1 Effect of ASC and storage time on psychrotrophic counts------------------106 


\section{INTRODUCTION}

Aquaculture is a growing industry in the United States. The decrease in wild seafood harvest and an increase in consumer demand has contributed to the increase in production of farmed fish. Most of these fish are marketed as fresh or frozen fillets and, post-mortem autolytic and microbiological changes reduce the storage stability of these products. The perishability of fish necessitates development of interventions to extend shelf life and preserve product quality.

Fish lipids are highly unsaturated and prone to oxidation during storage. Supplementation of fish diets with antioxidants may circumvent the deleterious effects of lipid oxidation. Several studies have focused on the post-harvest intervention of fillets with antimicrobials to reduce microbial spoilage. Expanded knowledge of ante and post-mortem factors affecting the storage of fresh and refrigerated fillets will be useful in improving product quality and marketability of these products. Thus, the purpose of this research was to 1) study the effect of

storage time and temperature on storage stability of fillets, 2) determine the effect of vitamin $\mathrm{E}$ supplementation on product quality and 3) evaluate the use of a postharvest antimicrobial additive to reduce spoilage of fillets and increase shelf life. 


\section{LITERATURE REVIEW}

\section{Postmortem changes in fish}

After harvest, there is a progressive decline in initial quality due to autolysis and changes resulting from bacterial growth and metabolism (Haard 1992). Both processes may lead to poor functionality of end products (Cheng and others 1979; Scott and others 1988) and reduce shelf life (Huss 1988).

\section{Bacterial changes}

Microorganisms are present on the skin and in the gills and intestines of freshly caught fish. Liston (1980) stated a normal range of $10^{2}-10^{7} \mathrm{CFU} / \mathrm{cm}^{2}$ on the skin surface. The gills and the intestines contain between $10^{3}$ and $10^{9} \mathrm{CFU} / \mathrm{g}$ (Shewan 1962). The bacterial flora on freshly-caught fish depends on the environment in which it is caught rather than on the fish species (Shewan 1977). Freshly caught fish and shell fish from warm waters generally carry mesophillic Gram-positive bacteria such as Micrococcus, Coryneforms and Bacillus. On the other hand, cold water species harbor predominately psychrophillic Gram-negative microbes including Moraxella, Acinetobacter, Pseudomonas, Flavobacterium and vibrio genera (Liston 1980; Cann 1977).

After death, the immune system no longer functions allowing bacteria to proliferate freely. During refrigeration or storage on ice, fish harvested from temperate water spoil more quickly than fish caught from tropical waters because of the high loads of psychrotrophic gram-negative spoilage bacteria. These bacteria have a short time lag time before growth and lead to spoilage (Liston 1980; Ward and Baj 1988). Gonzalez and others (1999) determined the initial bacterial flora 
associated with brown trout (Salmo trutta), wild pike (Esox lucius), and aquacultured rainbow trout (Oncorhynchus mykiss). Mesophilic counts for skin, gills and intestine were lower than $5 \times 10^{5} \mathrm{CFU} / \mathrm{cm}^{2}$. An influence of environment on the flora of fish was not observed in this study. The skin of brown trout and gills of rainbow trout carried significant numbers of Micrococcaceae that were absent in the water samples. Also, psychrotrophic Coryneforms present on the skin and gills of wild pike were not isolated from the surrounding water. Among the three species, gills and intestines of brown trout were the most contaminated, while gills and intestines of rainbow trout had the lowest numbers. Rodriguez and others (2001) reported initial bacterial counts of $5.27 \log _{10} \mathrm{CFU} / \mathrm{g}\left(30^{\circ} \mathrm{C}\right)$ and $4.87 \log _{10} \mathrm{CFU} / \mathrm{g}\left(25^{\circ} \mathrm{C}\right)$ for rainbow trout fillets. Initial counts for salmon fillets were more than $6 \log _{10} \mathrm{CFU} / \mathrm{g}$. trout fillets. Trout fillets were acceptable for 7 days; whereas, salmon fillets spoiled after 4 days of storage at $3^{\circ} \mathrm{C}$. Surface counts of aerobic psychrotrophic flora exceeded $10^{7}$ $\mathrm{CFU} / \mathrm{cm}^{2}$ in over-wrapped trout fillets stored at $1 \pm 1^{\circ} \mathrm{C}$ for 6 days (Giminez and others 2002). Catfish fillets tumbled with water at $60 \mathrm{rpm}$ for $10 \mathrm{~min}$, showed an increase in psychrotrophic counts with increasing storage time (Kim and others 2000).

The non-protein nitrogen (NPN) content of fish muscle is higher than NPN of muscle from terrestrial animals, ranging from 10\% to $40 \%$ (Venugopal and Shahidi 1996). The high concentration of these compounds is responsible for the delicate and different flavors typical of seafood. These compounds serve as a substrate for spoilage organisms and are thereby converted to obnoxious smelling volatile bases. These compounds in fish and shelfish are nucleotides, free amino acids, peptides, 
guanidino compounds, urea, and quaternary ammonium compounds (Finne 1992). Due to autolytic and bacterial activities, nitrogenous compounds are increased and thereby, produce amines, ammonia $\left(\mathrm{NH}_{3}\right)$, aldehydes, hydrogen sulphide $\left(\mathrm{H}_{2} \mathrm{~S}\right)$, mercaptans, indoles, and volatile bases and acids (Love 1980; Thomson and others 1980; Hultin 1984; Sikorski and Pan 1994). Fish contain trimethyl amine oxide (TMAO), and the amount of TMAO depends on species, environment, and in some cases, on fish age (Bystedt and others 1959). Bacterial enzymes convert TMAO to TMA (Babbit and others 1972). Marine fish contain $1-100 \mathrm{mg}$ of TMAO per 100 grams of muscle; whereas, fresh water fish contain $5-20 \mathrm{mg} / 100 \mathrm{~g}$ of muscle (Stansby and Olcott 1963). Production of TMA is dependent on species, sex, age, time of year and muscle type (Hughes 1959; Shirai and others 1988).

Volatile bases like trimethyl amine (TMA) and $\mathrm{NH}_{3}$ are used to measure fish deterioration (Antoine and others 2002). TVBN (total volatile base nitrogen) is a group test that includes TMA, dimethyl amines (DMA) and $\mathrm{NH}_{3}$. TVBN increases with degree of spoilage, and it is predominately due to enzymatic activity. Its component, TMA, is a direct result of bacterial activity, and in some cases, its correlation with bacterial counts is poor (Gill 1990). Antoine and others (2002) correlated the production of TVBN with aerobic plate counts $(r=0.71)$ and odor scores (0.84) in mahi-mahi (Coryphaena hippurus) fillets stored at $7^{\circ} \mathrm{C}$ for 10 days. On day 3 , TVBN values reached the maxium value of $30 \mathrm{mg} / 100 \mathrm{~g}$, a value considered the limit of acceptability (Liston 1982; Farn and Sims 1986) and it correlated well with bacterial counts of $10^{6} \mathrm{CFU} / \mathrm{g}$ and odor scores. Rainbow trout 
fillets exceeded a value $250 \mathrm{mg} / \mathrm{kg}$ on day 4 of storage on ice at $1 \pm 1^{\circ} \mathrm{C}$ (Giminez and others2002).

\section{Lipid oxidation}

Fish lipids are highly unsaturated and prone to oxidation (Xiong 1994; Church 1998). Unstable hydroperoxides produced from oxidation of fatty acids or triglycerides are converted to free radicals, that accelerate the rate of autoxidation. Products of these secondary reactions contribute to the oxidized flavor of seafoods (Gray 1978; Khayat and Schwall 1983). Secondary autoxidation products are primarly aldehydes, ketones, alcohols, small carboxylic acids and alkanes. Several of these aldehydes can be determined as thiobarbituric acid reactive substances (FAO 1995).

An increase in TBA value was observed in Black skipjack muscle stored on ice. Initially, a value of $1 \mathrm{mg}$ malonaldehyde $/ 100 \mathrm{~g}$ was observed and this value increased to $5.5 \mathrm{mg}$ malonaldehyde/100g after 24 days (Mazzora-Manzano and others 2000). Ryder and others (1984) reported, for mackerel (Trachurus novaezelandie), $8.3 \mathrm{mg}$ malonaldehyde/100g after 7 days of ice storage. Fresh rainbow trout fillets, over wrapped with low-density polyethylene and stored at $1 \pm 1^{\circ} \mathrm{C}$ for 20 days, showed an increase in TBARS value during initial stages of storage. However, TBARS decreased when fillets became spoiled (Giminez and others 2002). This decrease may be due to the reaction of malondialdehyde with protein degradation products (Known and others 1965).

Amino acids, heme compounds, and organic acids, catalyze oxidation reactions alone or in association with trace metal ions (Castell and others 1969; El-Zeany and 
others 1975; Jurewicz and Salmonowicz 1973). Khayat and Schwall (1983) studied the effect of copper, iron, and hemin on oxidation of Alaskan Pollack flesh homogenate and mackeral oil. They demonstrated acceleration of oxidation by these ions, and they reported the decreasing order of relative effectiveness in absorbing oxygen as: $\mathrm{Fe}^{2+}>$ hemin $>\mathrm{Cu}^{2+}>\mathrm{Fe}^{3+}$.

Enzyme systems that participate in oxidation of fish lipids include lipoxygenase (German and Kinsella 1985), localized in the skin and gills, and microsomal enzyme systems (McDonald and Hultin 1987). Lipid oxidation may lead to a decrease in nutritional quality, including loss of essential fatty acids, fat-soluble vitamins and essential amino acids, as well as possible toxicity development (Pearson and others 1983).

\section{Changes in texture}

Tenderness is the most important palatability attribute and sensory characteristic of fish and other muscle tissues (Ashie and others 1996). Fish and shell fish muscle contain less connective tissue, and the cross-links formed by their collagens are not as extensive as mammals (Suyama and Konosu 1987). Tenderization or flesh softening is associated with the disappearance of Z-disks, disassociation of the actomyosin complex, destruction of connectin, and general denaturation of collagenous tissues (Hatori 1986; Koohmarie and others 1986; Koohmarie and others 1988; Robbins and others 1979; Suyama and Konosu 1987). Færgemand and others (1995) evaluated the effect of post mortem storage time on fillet quality of rainbow trout (Oncorchynchus mykiss) stored on ice. Prolonged storage time had a negative effect on fillet texture. Fillets became softer with increasing storage time 
(Azam and others 1989; Ando and others 1992). Sato and others (1991) showed that, in rainbow trout, solubility of type $\mathrm{V}$ collagen increases significantly during ice storage of fish and that the fillets become soft during chilled storage. Gutted trout fillets stored in ice $\left(4-5^{\circ} \mathrm{C}\right)$ were acceptable for six days; subsequent storage resulted in dry texture and a slight bitter flavour (Rodriguez and others1999).

$\mathrm{Ca}{ }^{2+}$ dependent proteases and lysosomal cathepsins cause textural changes during postmortem storage (Koohmarie and others 1986; Koohmarie and others 1988; Jiang and others 1992; Jiang and others 1990). In mammals these autolytic changes are desirable, resulting in more tender meat. However, in fish these autolytic changes have deleterious effects resulting in texture degradation. Postmortem reduction in fish muscle $\mathrm{pH}$ affects the physical properties of muscle. As $\mathrm{pH}$ drops, the net surface charge on muscle proteins is reduced causing them to partially denature and lose some of their water holding capacity. Loss of water binding ability has a detrimental effect on fish texture. Love (1983) reported that texture of cooked cod becomes soft or sloppy when pH increases to above 7 .

\section{Factors influencing fish spoilage}

Several factors influence spoilage of fish. However, initial handling techniques, temperature, and $\mathrm{pH}$ are perhaps the most important.

\section{Handling}

Some post harvest treatments may include stunning, bleeding, scaling, washing, and gutting and heading. Poor post harvest handling practices may promote deterioration. Freshly caught fish are sprayed or washed with clean water to remove surface contamination; removal of surface slime from very fresh fish may affect the 
market life of fish as slime may contain antibacterial components such as lysozymes (Haard 1992). Bleeding of white-fleshed fish species often results in more attractive products. It may also minimize off-flavors, improve the quality of surimi prepared from such products, and contribute to an extended shelf life. However, it does not improve post harvest quality in all species (Haard 1992a). Gutted and headed haddock had lower psychrotrophic counts than the non eviscerated fish, although the differences were not significant (Ashie and others 1996). Gutted and headed orange roughy had an increase in shelf life due to delay in degradation of inosine monophosphate rather than a reduction in bacterial activity (Scott and others 1986).

\section{$\underline{\text { Temperature and } \mathrm{pH}}$}

Temperature affects the rate of fish spoilage through its impact on bacterial and autolytic enzymes, endogenous to fish. Temperature also affects the rate at which bacteria multiply (Rosinvalli and Charm 1975). Most of the biochemical activities are slowed down at low temperature. Olley and Lovern (1960) showed that protein denaturation and phospholipid hydrolysis is lower at reduced storage temperatures. Hydrolysis at $-14^{\circ} \mathrm{C}$ was 10 times greater than at $-22^{\circ} \mathrm{C}$. Ashie and others (1996) reported that the temperature coefficient of fish is about 5 , between 0 and $6^{\circ} \mathrm{C}$, and the shelf life of properly handled and iced fish is about 8 to 12 days for most fish. Temperature can also cause discoloration in fish by influencing the sensitivity of myoglobins to autoxidation (Liningston and Brown 1981). Haard (1992a) reported that, during iced storage, initial color of seafood is changed. The bright shiny appearance of skin becomes dull and faded; the translucent appearance of white 
muscle becomes opaque; and the bright red hue of the dark muscle becomes dull or brown. A cooked appearance is caused by rapid post harvest glycolysis and failure to rapidly cool the carcass (Haard 1992).

The $\mathrm{pH}$ of live fish is close to 7 , and the postmortem $\mathrm{pH}$ of fish muscle can vary between 6.0 to 7.1 , depending on season, species, and other factors (Simeonidou and others 1998; Church 1998). Postmortem pH decline is caused by lactic acid generated from glycolysis under anoxic conditions. The rate and extent of $\mathrm{pH}$ decline influences meat quality (Ashie and others 1996); whereas, during extended storage $\mathrm{pH}$ increases due to ammonia and amines produced by bacteria. Bilinski and others (1983) reported that, in spiny dog fish, $\mathrm{pH}$ changes are strongly influenced by spoilage temperature. Rapid chilling of dog fish to $0^{\circ} \mathrm{C}$ delayed the breakdown of nitrogenous compounds, thereby reducing the rate of spoilage. Rodriguez and others (2001) reported that $\mathrm{pH}$ increased from 6.42 to 6.61 in trout fillets stored at $3^{\circ} \mathrm{C}$ for 10 days. Similar results were observed in rainbow trout (Giminez and others 2002).

\section{Antioxidant stabilization of lipids}

Antioxidants may circumvent the deleterious effects of lipid oxidation on muscle food quality. Antioxidants are commonly incorporated into fish feeds that contain a high concentration of polyenic fatty acids to prevent lipid oxidation (NRC 1993). Antioxidants can prevent lipid oxidation by reacting with peroxyl or alkoxyl radicals; this action terminates lipid autoxidation by scavenging free radicals. Several antioxidants such as tocopherols, carotenoids, and ascorbic acid have been used in fish feed to reduce lipid oxidation and color loss in fish. Carotenoids may function as 
antioxidants by quenching triplet sensitizers, singlet oxygen, and trapping free radicals (Krinsky 1992,1993). Bell and others (2000) suggested that vitamin E and the carotenoid, astaxanthin, have antioxidant functions in Atlantic salmon (Salmo salar). Ethoxyquin, BHT (3,5-di-tert-butyl-4-hydroxytoluene), BHA (2(3)-tertbutyl-4hydraxyanisole), and propyl gallate are some of the synthetic antioxidants used in fish feed (NRC 1993). Gatlin in and others (1992) conducted two feeding trials to study the effect of dietary vitamin $E$ and synthetic antioxidants (ethoxyquin, butylated hydraxyanisole, butylated hydroxytoluene and Endox super ${ }^{\mathrm{TM}}$ ) on composition and storage quality of channel catfish (Ictalurus punctatus). Fillet samples were subjected to forced oxidation by incubating under a stream of oxygen at $40^{\circ} \mathrm{C}$ for $2 \mathrm{~h}$ prior to thoibarbituric acid analysis. Forced oxidation of fillets was reduced in fish fed high levels of vitamin $\mathrm{E}$; none of the synthetic antioxidants reduced oxidation. Neither vitamin E nor the synthetic antioxidants had any effect on growth, and feed efficiency of whole fish or proximate composition and fillet.

\section{Vitamin E requirements}

The antioxidant function of vitamin $\mathrm{E}$ makes it an essential nutrient in human and other animal diets (Watanabe and others 1981a, 1981b; Drevon 1991). The minimum requirement of vitamin $E$ in rainbow trout ranges from 30 to $100 \mathrm{mg} / \mathrm{kg}$ of diet (NRC 1993). Vitamin E is an essential nutrient in salmonid diets (Watanabe 1990), and it is usually supplied as a-tocopherol acetate. Vitamin E is typically added at a level of 300-500 mg/kg diet (Gabaudan and Hardy 2000).

Common signs of vitamin E deficiency are muscular dystrophy involving atrophy and necrosis of white muscle fibers; edema of heart, muscle, and other tissues due 
to increased capillary permeability allowing exudates to escape and accumulate; anemia and impaired erythropoiesis; depigmentation; and ceroid pigment in liver (NRC 1993). Vitamin E deficiency signs have been studied in Atlantic salmon (Poston and others 1976), channel catfish (Lovell and others 1984), common carp (Watanabe and others 1981a) and rainbow trout (Cowey and others 1981, 1983; Hung and others 1981; Watanabe and others 1981b). Poston and Livingston (1969) reported that supplementation with very high doses of $\mathrm{DL}$ - $\alpha$-tocopherol $(5,000 \mathrm{mg}$ $/ \mathrm{kg}$ of diet) reduced the concentration of erythrocytes in trout blood. Supplementation with $2500 \mathrm{mg} / \mathrm{kg}$ of $\alpha$-tocopherol did not produce adverse effects in channel catfish (Lovell and others 1984).

\section{Tissue distribution of vitamin $\mathrm{E}$}

Vitamin $\mathrm{E}$ is a major lipid soluble, free radical scavenging antioxidant in vivo. Tocopherols in active biological cells concentrate largely in phospholipid rich cellular regions like the mitochondria and microsomes (Krishnamurthy and Bieri 1963; Gruger and Tappel 1971). Hamre and Lie (1997) suggested that each organ may have a unique combination of mechanisms whereby they take up lipids and tocopherols from plasma. Zhang and others (1996) examined the dietary uptake of vitamin $E$ in laboratory rats supplemented with vitamin $E(1 \mathrm{mg} / \mathrm{kg}$ of diet). Plasma $\alpha-$ tocopherol concentration reached a maximum after $48 \mathrm{~h}$, and the liver was the main organ where the vitamin accumulated. Kidney, heart, muscle and brain levels continued to increase throughout a six week period. The level of $\alpha$-tocopherol decreased slowly when the supplement was removed from the diet. Catignani and Bieri (1977) reported the presence of a a-tocopherol-binding protein in rat liver, and 
the protein $(30 \mathrm{kDa})$ exists uniquely in the hepatocytes of rat liver and regulates plasma tocopherol concentration by preferentially incorporating a-tocopherol into nascent, very low density lipoproteins (Dutta-Roy and others 1994). Tissue distribution of $\alpha$ and $\gamma$-tocopherol in Atlantic salmon (Salmo salar) was studied by Parazo and others (1998). Their results demonstrated the importance of the liver in selecting a-tocopherol over $\gamma$-tocopherol; additionally, a protein analogous to the 30 $\mathrm{kDa}$ a-tocopherol binding protein exists in Atlantic salmon liver because the liver appeared to be the most biased organ for accumulating a-tocopherol. During restricted intake of $\alpha$-tocopherol, loss of $\alpha$-tocopherol in muscle and liver was greater than in other tissues. Similar results were observed by Cowey and others (1981) in rainbow trout, suggesting the possibility of translocation of tocopherols from the muscle to other critical organs during deprivation.

Vitamin E and oxidative stability of fillets

Fish lipids are rich in omega-3, polyunsaturated fatty acids (Stephan and others 1995), and oxidation of polyunsaturated fatty acids causes rancidity in the fish that often results in deterioration of color, texture and flavor (Frigg and others 1990; Waagbø and others 1993). Leibovitz and others (1990) and Hu and others (1989) demonstrated that enrichment of tissues with $\alpha$-tocopherol reduces oxidation of fatty acids in tissues subjected to activate oxidation, even if these tissues contain high levels of $n-3$ polyunsaturated fatty acids.

Membrane-bound a-tocopherol stabilizes membrane lipids in broiler and pork muscle, resulting in reduced lipid oxidation during refrigerated and frozen storage (Buckley and others 1988). Similarly, O'Keefe and Noble (1978) found that dietary 
levels of $\alpha$-tocopherol above $400 \mathrm{mg} / \mathrm{kg}$ diet were effective in increasing the storage stability of channel catfish fillets.

Frigg and others (1990) studied the effect of dietary vitamin E levels on oxidative stability of trout fillets. Rainbow trout (Salmo gairdneri) were fed 0, 50, 100, and 200 IU of supplemental vitamin E/kg feed for 85 days. Levels of $\alpha$-tocopherol in plasma, liver and fillets were directly related to dietary vitamin E levels. The amount and characteristics of lipids were not influenced by vitamin E. Malondialdehyde (MDA) values were markedly dependent on dietary vitamin E level and a-tocopherol level in the fillet.

Boggio and others (1985) reported a significant increase in tissue a-tocopherol levels of rainbow trout (Salmo gairdneri), fed fish oil or swine fat and supplemented with 500 and $1500 \mathrm{mg}$ of $\alpha$-tocopherol acetate per $\mathrm{kg}$ of diet, compared to fish fed 0 and $50 \mathrm{mg} / \mathrm{kg}$ diet for 4 months prior to harvest. Eventhough fish fed $1500 \mathrm{mg} / \mathrm{kg}$ vitamin $\mathrm{E}$ had higher a-tocopherol levels than trout fed $500 \mathrm{mg} / \mathrm{kg}$, these levels did not reduce lipid oxidation after frozen storage at $-80^{\circ} \mathrm{C}$ for 4 months. Lipid oxidation did not decrease in fish fed high levels when compared to 0 and $50 \mathrm{mg} / \mathrm{kg}$ vitamin $\mathrm{E}$ fed fish after storage at $-20^{\circ} \mathrm{C}$ for 10 months. Dietary $\alpha$-tocopherol concentration did not affect fatty acid composition; whereas, dietary lipid source altered the fatty acid composition of muscle and viscera. Dietary fat source or a-tocopherol acetate did not affect sensory attributes of trout fillets evaluated fresh or after prolonged storage. Similarly, in turbot (Scophthalmus maximus), a-tocopherol supplementation (70 and $320 \mathrm{mg} / \mathrm{kg}$ of diet) reduced thiobarbituric acid reactive substances (TBARS) in fresh tissue. Peroxidation of polyunsaturated fatty acids (PUFA) is inhibited more in liver 
than in muscle. Storing of muscle at $-20^{\circ} \mathrm{C}$ for 6 months increased muscle TBARS value, and these values were higher in turbot fed cod liver oil or low $\alpha$-tocopherol diets (Stephan and others 1995). Vitamin E supplemented (300 mg/kg diet) Atlantic salmon fillets had three times higher $\alpha$-tocopherol levels than fillets from the nonsupplemented group. Vitamin E supplementation did not alter fatty acid composition or lipid levels. Fillet $\alpha$-tocopherol content was not affected by freezing, storing, or smoking. Sensory parameters were not influenced by lipid quality or dietary supplementation with $\alpha$-tocopherol (Waagbø and others 1993).

Chaiyapechara and others (2003) conducted a 10 week feeding trial on rainbow trout (Oncorhynchus mykiss). Increasing vitamin E concentration lowered TBARS values in fillets stored for 7 days at $4^{\circ} \mathrm{C}$ and $-30^{\circ} \mathrm{C}$. Dietary vitamin levels had no effect on $L^{*}$ value. However, an increase in dietary lipid concentration increased whiteness $\left(L^{*}\right)$ of fillets, but not the $a^{*}$ and $b^{*}$ values. They suggested that increasing the concentration of vitamin $\mathrm{E}$ from 300 to $1500 \mathrm{mg}$ could reduce the "fishy" aroma in fillets of trout fed a $30 \%$ lipid diet.

\section{Chemical preservatives and shelf life extension}

The growing demand for fresh fish has necessitated development of new technologies to extend shelf life. Chemical preservatives are applied as dips

or additives to delay spoilage of fresh fish. Chemicals used to delay microbial spoilage include sodium hypochlorite, broad spectrum antibiotics, ethylenediaminetetraacetic acid (EDTA), glucose oxidase and organic acids (Haard 1992). 
Kim and others (1997) showed that TBA values of Salmon and red grouper fillets treated with 100 and $200 \mathrm{ppm} \mathrm{ClO}_{2}$ are greater than control and $20 \mathrm{ppm}$ fillets; and a dose dependent response was observed. Chlorine dioxide did not affect fatty acid composition of fillets. There were no differences in monounsaturated and polyunsaturated fatty acids compared to controls. Kim and others (1998) reported that chlorine dioxide did not affect proteins, fats, vitamins and minerals in Salmon and red grouper. Zhang and others (2003) reported that fresh haddock fillets treated with 200 ppm sodium chlorite can be stored for about 18 days at $4^{\circ} \mathrm{C}$.

Acidified sodium chlorite (ASC) is approved by the U.S. Food and Drug Administration as a 'secondary direct food additive permitted in food for human consumption'. ASC is approved at a concentration of $500-1,200 \mathrm{ppm}$ for use on poultry, red meat, comminuted meat products and processed fruits and vegetables to reduce bacterial contamination. It can also be used in water or ice at concentrations of $40-50 \mathrm{ppm}$ to rinse, wash, thaw, transport, or store seafood. ASC is an antibacterial agent prepared by mixing sodium chlorite with a generally recognized - as - safe acid (Anonymous 1999); acids that are typically used include citric acid and phosphoric acid. The antimicrobial acitivity of acidified sodium chlorite is attributed to the oxidative effect of chlorous acid that is generated when the chlorite ion is converted to its acid form under acidic conditions. Chlorous acid is a metastable oxychlorine species that decomposes to form chlorate ion, chlorine dioxide, and chloride ion (Gordon and others 1972). As chlorous acid is being depleted, residual chlorite produces more chlorous acid and continues the antimicrobial activity until the solution evaporates or dries on the product surface. 
The solution is prepared immediately before its application because the reactions occurs instantaneously in the mixed solution (Castillo and others 1999). It is hypothesized that the mode of action of ASC is due to the uncharged chlorous acid; it penetrates bacterial cell walls and disrupts protein synthesis by reacting with sulfhydryl, sulfide, and disulfide containing amino acids and nucleotides. The undissociated acid adversely affects amino acid transport by facilitating proton leakage into cells and thereby increases energy use by cells to maintain internal $\mathrm{pH}$ (Warf and Kemp 2001). When ASC comes in contact with organic matter, a number of oxychlorous antimicrobial intermediates are formed. These intermediates are broad spectrum germicides that act by breaking oxidizable bonds on cell membrane surfaces. Su and Morrissey (2003) demonstrated that the antimicrobial acivity of ASC was not due to low $\mathrm{pH}$, but primarly due to the generation of bactericidal chemicals, including chlorine dioxide, and hypochlorous acid $\left(\mathrm{HClO}_{2}\right)$.

Castillo and others (1999) compared the efficacy of phosphoric acid-activated, ASC and citric acid-activated, ASC as decontaminants on Escherichia coli O157: $\mathrm{H} 7$ and Salmonella typhimurium incoculated beef carcasses. Water wash treatment followed by citric acid-ASC spray significantly reduced Escherichia coli O157: H7 and Salmonella typhimurium by 4.5 and $4.6 \log \mathrm{CFU} / \mathrm{cm}^{2}$ respectively; whereas, water wash alone resulted in a reduction of only 2.9 log units.Nonetheless, 30-50 \% of the carcasses treated by ASC yielded countable colonies. Treatment of prewashed poultry carcasses with ASC reduced total aerobes by $90.7 \%$, Escherichia coli by $99.6 \%$ and total Coliforms by $98.5 \%$. A mild whitening of the skin was 
observed in carcasses treated with a 1,200 ppm ASC solution (Kemp and others 2000).

Kemp (2001) reported that immersion dipping of three species of snapper for 2 minutes in ASC followed by storage at $-3^{\circ} \mathrm{C}$ in ice or ice/brine solution increased shelf life between 12.9 and 19.1 days depending on the species. Similarly, shelf life of fresh cod was extended by 10 days over the control, untreated cod. Eun and others (2001) dipped whole croaker in different concentrations of ASC for 5 and 10 min. Dipping whole croaker in $50 \mathrm{ppm}$ ASC resulted in a 1-log reduction of psychrotrophic bacteria and total coliforms. A 600 ppm solution resulted in a 1-log reduction of mesophilic bacteria and a 1-log reduction in Gram-negative bacteria. Whereas, a 1000 ppm dip resulted in a 3-log reduction of mesophilic bacteria, and a 2-log reduction of psychrotrophic bacteria. A 1000 ppm ASC dip caused a bleached appearance on whole croaker. There were no differences in these data associated with dipping times. Su and Morrissey (2003) studied the antimicrobial activity of ASC with a focus on Listeria monocytogenes in salmon. Total plate counts of skinless fillets ranged from 2.83 to $2.89 \mathrm{CFU} / \mathrm{g}$, and ASC treatment (50 ppm) reduced the initial counts by $0.3 \log$ units. Storage of fillets in ice or at $5^{\circ} \mathrm{C}$ for 7 days increased total plate counts in fillets. However, counts for acidified sodium chlorite treated samples were $0.34\left(5^{\circ} \mathrm{C}\right)$ and 0.61 (in ice) $\log _{10}$ units lower than the control samples. ASC solution did not affect anaerobic counts. ASC treatment of salmon skin reduced total plate counts by $0.43 \log \mathrm{CFU} / \mathrm{cm}^{2}$. Compared to the control samples, Listeria monocytogenes counts were 0.2 log units lower in fillets stored in ASC ice and 0.62 log units lower in fillets washed with ASC solution and 
stored in ASC ice for 7 days. Dipping of salmon fillets in ASC solution at a sodium chlorite concentration of $100 \mathrm{ppm}$ for 1 min resulted in noticeable color loss. Similar discoloration was observed in salmon fillets treated with 100 or 200 ppm of chlorine dioxide (Kim and others 1999). 


\section{REFERENCES}

Anonymous. 1999. 21 CFR 173.325. Acidified sodium chlorite solutions. Code of Federal Regulations, Office of the Federal Register, U.S. Government Printing Office, Washington, DC.

Ando M, Toyohara H, and Sakaguchi M. 1992. Post-mortem tenderization of rainbow trout muscle caused by the disintegration of collagen fibers in the pericellular connective tissue. Nippon Suisan Gakkaishi. 58(3):567-570.

Antoine FR, Wei Cl, Otwell WS, Sims CA, Littell RC, Hogie AD, and Marshall MR. 2002. TVB-N correlation with odor evaluation and aerobic plate count in mahi-mahi (Coryphaenahippurus). J. Food Sci. 67(9):3210-3214.

Ashie INA, Smith JP, and Simpson BK. 1996. Spoilage and shelf-life extension of fresh fish and shellfish. Critical Reviews in Food Science and Nutrition. 36(1\&2): 87121.

Azam k, Mackie IM, and Smith J. 1989. The effect of slaughter method on the quality of rainbow trout (Salmo gairdneri) during storage on ice. International Journal of Food and Technology. 24:64-79.

Babbit JK, Crawford DL, and Law DK. 1972. Decomposition of trimethylamine oxide and changes in protein extractability during frozen storage of minced and intact hake (Merluccius products) muscle. J. Agric. Food Chem. 20:1052.

Bell JG, McEvoy J, Tocher DR, and Sargent JR. 2000. Depletion of $\alpha$-tocopherol and asthaxanthin in Atlantic salmon (Salmo salar) affects autoxidative defense and fatty acid metabolism. J. Nutr. 130:1800-1808.

Bilinski E, Jonas REE, and Peters MD. 1983. Factors controlling the deterioration of the spiny dog fish during iced storage. J.Food Sci. 48:808.

Boggio SM, Hardy RW, Babbitt JK, and Brannon EL. 1985. The influence of dietary lipid source and alpha-tocopheryl acetate level on product quality of rainbow trout (Salmo gairdneri). Aquaculture. 51:3-24.

Buckley DJ, Gray JI, Lin CF, Ashgar A, Pearson AM, Booren AM, and Miller ER. 1988. Membrane lipid peroxidation in relation to meat stability. In: Chandler CS, and Thorton RF, editors. 34th Int. Congr. Meat Sci. and tech; Brisbane; Australia. p A 254-256.

Bystedt J, Swenne L, and Ass HW. 1959. Determination of trimethylamine oxide in fish muscle. J. Sci. Food Agrc. 10:301. 
Catignani GL, and Bieri JG. 1977. Rat liver $\alpha$-tocopherol binding protein. Biochim. Biophys. Acta. 497: 349-357.

Cann DC. 1977. Bacteriology of shellfish with reference to international trade. In: Handling, processing and marketing of tropical fish. London:Tropical products Inst. p 377.

Castillo A, Lucia LM, Kemp G K, and Acuff GR. 1999. Reduction of Escherichia coli O157:H7 and Salmonella typhimurium on beef carcass surfaces using acidified sodium chlorite. J. Food Prot. 62(6):580-584.

Castell CH, and Bishop D. 1969. Effect of heme compounds on the development of rancidity in muscle od cod, flounder, scallop, and lobster. J. Fish. Res. Board Can. 26(9):2299.

Chaiyapechara S, Casten MT, Hardy RW, and Dong FM. 2003. Fish performance, fillet characteristics, and health assessment index of rainbow trout (Oncorhynchus mykiss) fed diets containing adequate and high concentrations of lipid and vitamin $\mathrm{E}$. Aquaculture. 219:715-738.

Cheng CS, Hamann DD, Webb NB, and Sidwell V. 1979. Effects of species and storage time on minced fish gel texture. J. Food Sci. 44:1087-1092.

Church N. 1998. MAP fish and crustaceans sensory enhancement. Food Sci Tech Tod. 12(2):73-83. Bull Jap Soc Sci Fish 24:749-750.

Cowey CB, Andron JW, Walton MJ, Youngson A, and Knox D. 1981. Tissue distribution, uptake, and requirement for $\alpha$-tocopherol of rainbow trout (Salmo gairdneri) fed diets with a minimal content of unsaturated fatty acids. J. Nutr. 111:1556-1567.

Cowey CB, Adron JW, and Youngson A.1983. The vitamin E requirement of rainbow trout (Salmo gairdneri) given diets containing polyunsaturated fatty acids derived from fish oil. Aquaculture. 30:85-93.

Drevon CA. 1991. Absorption, transport, and metabolism of vitamin E. Free Rad. Res. Comms. 14(4):229-246.

Dutta-Roy AK, Gordon MJ, Campbell FM, Duthie GG, and James WPT. 1994. Vitamin $\mathrm{E}$ requirements, transport, and metabolism: Role of $\alpha$-tocopherol binding proteins. J. Nutr. Biochem. 5:562-570.

El-Zeany BA, Janicek G, and Pokorny J. 1975. Effect of antioxidant on discoloration of lipid protein mixtures. Z. Lebensm.-Unters.-Forsch. 158:93. 
Eun JB, Koo J, and Jahncke ML. 2001. Reduction in bacterial numbers on whole croaker dipped acidified sodium chlorite [abstract]. In: IFT Annual Meeting Book of Abstracts; 2001; New Orleans, La. Chicagolll.: Institute of Food Technologists. Abstract nr 73F-3.

Farn G, and Sims GG. 1986. Chemical indices of decomposition in tuna. In: Kramer $\mathrm{DE}$, Liston J, editors. Seafood quality determination. Proceedings of an inter-national symposium. Amsterdam: Elsevier Science Publishers. p175-183.

Færgemand J, Rønshlodt B, Alsted N, and Børrsen T. 1995. Fillet texture of rainbow trout as affected by feeding strategy, slaughtering procedure and storage post mortem. Wat. Sci. Technol. 31(10):225-231.

Finne G. 1992. Nonprotein nitrogenous compounds in fish and shell fish. In: Flick G, Martin RE, editors. Advances in sea food biochemistry. Lancaster, Pa.: Technomic publishings Co. Inc. p 393-401.

Food and Agriculture Organization of the United Nations. 1995. Postmortem changes in fish. In: Quality and quality changes in fresh fish. Chapter 5. FAO Fisheries technical paper - 348. Rome, Italy. Via internet. Accesed on July 152003.

Frigg M, Prabucki AL, and Ruhdel EU. 1990. Effect of dietary vitamin E levels on oxidative stability of trout fillets. Aquaculture. 84:145-158.

Galtin DM III, Bai SC, and Erickson MC. 1992. Effects of dietary vitamin E and synthetic antioxidants on composition and storage quality of channel catfish, Ictalurus punctatus . Aquaculture. 106:325-332.

Gabaudan J, and Hardy RW. 2000. Vitamin sources for fish feeds. In: Stickeny RR, editor. Encyclopedia of aquaculture. New York: wiley.p 961-965.

German JB, and Kinsella JE. 1985. Lipid oxidation in fish tissues. Enzymatic initiation via lipoxygenase. J. Agri. Food Chem.33:680-683.

Gill TA. 1990. Objective analysis of seafood quality. Food Rev Int. 6(4):681-714.

Giminez B, Roncales R, and Beltran JA. 2002. Modified atmosphere packaging of filleted rainbow trout. J. Sci Food Agric. 82:1154-1159.

Gonzalez C-J, Diaz-L T-M, Lopez-G M-L, Prieto M, and Otero A. 1999. Bacterial microflora of wild brown trout (Salmo trutta), wild pike (Esox lucis), and aquacultured rainbow trout (Oncorhynchus mykiss). J. Food Prot. 62 (11): 1270-1277.

Gordon G, Kieffer RB, and Rosenblatt DH. 1972. The chemistry of chlorine dioxide. In: Lepard SJ, editor. Progress in inorganic chemistry. Vol 15. Newyork: Wileyinterscience publishers. p201-286. 
Gray JI. 1978. Measurement of lipid oxidation: a review. J. Am. Oil. Chem. Soc. 55:539.

Gruger EH Jr, and Tappel AL. 1971. Reaction of biological antioxidants III. Composition of biological membranes. Lipids. 6:147-148.

Haard NF. 1992. Technological aspects of extending prime quality of seafood: A review. Journal of Aquatic Food Product Technology. 1(3/4):9-27.

Haard NF. 1992a. Biochemistry and chemistry of color and color changes in sea foods. In: Martin R, Ory R, and Flick G, editors. Seafood biochemistry, composition and quality. Lancaster Pa:Technomic. p 305-360.

Hamre K, and Lie $\varnothing$. 1997. Retained levels of dietary $\alpha-, \gamma-, \delta$ - tocopherol in tissues and body fluids of Atlantic salmon, Salmo salar L. Aquaculture. Nutrition. 3:99-107.

Hatori A. 1986. Aging of meat. Kagaku to Seibutsu (Chemistry and Biology). 24:789.

Hu M-L, Frankel EN, Leibovitz BE, and Tappel AL. 1989. Effect of dietary lipids and vitamin $\mathrm{E}$ on in vitro lipid peroxidation in rat liver and kidney homogenates. J. Nutr. 119:1574-1582.

Hughes RB. 1959. Chemical studies on the herring (Clupea harengus) I. Trimethlyamine oxide and volatile amines in fresh, spoiling and cooked herring flesh. J Sci. Food Agric. 10:431-436.

Hultin HO. 1984. Postmortem biochemistry of meat and fish. J Chem Ed. 61(4):289298.

Hung SSO, Cho CY, and Slinger SJ. 1981. Effect of oxidized fish oil, DL- $\alpha-$ tocopheryl acetate and ethoxyquin supplementation on the vitamin $E$ nutrition of rainbow trout (Salmo gairdneri) fed practical diets. J. Nutr. 111:648-657.

Huss HH. 1988. Fresh Fish-Quality and Quality Changes. FAO Fisheries Series No. 29. Rome:Food and Agricultural Organization. p 132.

Jiang S-T, Wang YT, Gan B-S, and Chen C-S. 1990. Role of pepstatin-sensitive proteases on the postmortem changes of tilapia muscle myofibrils. J. Agric. Food Chem. 38: 1464.

Jiang S-T, Wang YT, and Chen C-S. 1992. Lysosomal enzyme effects on the post mortem changes in tilapia muscle myofibrils. J. Food Sci. 57(2): 277.

Jurewicz I, and Salmonowicz J. 1973. Probl. Postepow Nauk. Roln. 136:119. 
Kemp GK, Aldrich ML, and Waldroup AL. 2000. Acidified sodium chlorite antimicrobial treatment of broiler carcasses. J. Food Prot. 63 (8):1087-1092.

Kemp GK. 2001. Potential applications of acidified sodium chlorite for pathogen reduction and shelf life extension on sea food [abstract]. In: IFT Annual Meeting Abstracts; 2001; New Orleans, La. Chicago III.: Institute of Food Technologists. Abstract nr 91-8.

Khayat A, and Schwall D. 1983. Lipid oxidation in sea food. Food Technol. 37:130.

Kim JM, Lee YS, O'Keefe SF, and Wei Cl. 1997. Effect of chlorine dioxide treatment on lipid oxidation and fatty acid composition in salmon and red grouper

fillets. J. Am. Oil. Chem. Soc. 74: 539-542.

Kim JM, Du WX, Otwell WS, Marshall MR, and Wei, Cl. 1998. Nutrients in salmon and red grouper fillets as affected by chlorine dioxide $\left(\mathrm{ClO}_{2}\right)$ treatment.

J. Food Sci. 63(4): 629-633.

Kim JM, Huang TS, Marshall MR, and Wei.Cl. 1999. Chlorine dioxide treatment of sea foods to reduce bacterial loads. J. Food Sci. 64(6): 1089-1093.

Kim TJ, Silva JL, Chamul RS, Chen TC. 2000. Influence of ozone, hydrogenperoxide or salt on microbial profile, TBARS and color of channel catfish fillets. J. Food Sci. 65(7):120-1213.

Known TW, Menzel DB, and Olcott HS. 1965. Reactivity of malonaldehyde with food constituents. J. Food Sci. 30:808-813.

Koohmarie M, Schollmeyer JE, and Dutson TR. 1986. Effect of low calciumrequiring calcium-activated factor on myofibrils under varying $\mathrm{pH}$ and temperature conditions. J. Food Sci. 51:28.

Koohmarie M, Babiker AS, Merkel RA, and Dutson TR. 1988.Roll of $\mathrm{ca}^{2+}$-dependent proteases and lysosomal enzymes in postmortem changes in bovine skeletal muscle. J. Food Sci. 53:1253.

Krinsky NI. 1992. Mechanism of action of biological antioxidants. Proceed. Soc. Exp. Biol. Med. 200: 248-254.

Krinsky NI. 1993. Action of carotenoids in biological systems. Ann. Rev. Nutr. 13:246.

Krishnamurthy S, and Bieri JG. 1963. The absorption, storage, and metabolism of $\alpha-$ tocopherol- $\mathrm{C}^{14}$ in the rat and chicken. J. Lipid Res. 4:330-336. 
Leibovitz BE, Hu M-L, and Tappel AL. 1990. Lipid peroxidation in rat tissue slices: effect of dietary vitamin E, corn oil-lard and menhaden oil. Lipids. 25:125-129.

Liston J. 1980. Microbiology in fishery science. In: Connell JJ,editors. Advances in fishery science and technology. Farnham, England: Fishing News Books Ltd. p138157.

Liston J. 1982. Recent advances in the chemistry of iced fish spoilage. In: Martin RE, Flick GJ, Hebard CE, Ward DR, editors. Chemistry and biochemistry of marine food products. Westport, Conn.: AVI Publishing Co. P 27-37.

Liningston DJ, and Brown WD. 1981. The chemistry of myoglobin and its reactions. Food Technol. 35(5):244.

Love RM. 1980. The chemical biology of fishes. Vol 2. London: Academic Press Inc. p 67-132, 158-218.

Love RM. 1983. Texture and fragility of fish muscle cells. J. Texture Studies. 14:323352.

Lovell RT, Miyazaki T, and Rabengnator S. 1984. Requirement for $\alpha$-tocopherol by channel catfish diets low in polyunsaturated triglycerides. J. Nutr. 114: 894-901.

Mazzora-Manzano MA, Pacheco-Aguilar R, Díaz-Rojas El, and Lugo-Sanchez ME. 2000. Postmortem changes in black skipjack muscle during storage in ice. J Food Sci 65(5):774-779.

McDonald RE, and Hultin HO. 1987. Some characteristics of the enzymic lipid peroxidation system in the microsomal fraction of flounder skeletal muscle. J. Food Sci. 52(1):15.

NRC (National Research Council) .1993. Nutrient Requirements of Fish . National Academy Press, Washington DC, USA. p 23-35.

O'Keefe T, and Noble RL. 1978. Storage stability of channel catfish (Ictalurus punctatus) in relation to dietary level of $\alpha$-tocopherol. J. Fish. Res. Board Can. 35 (4): 457-460.

Olley J, and Lovern JA. 1960. Phosphilipid hydrolysis in cod flesh stored at various temperatures. J. Sci. Food Agric. 11:1664.

Pearson AM, Gray JI, Wolzak AM, and Horenstein NA. 1983. Safety implications of oxidized lipids in muscle foods. Food Technol. 37(7):121-129.

Parazo MPM, Lall SP, Castell JD, and Ackman RG. 1998. Distribution of $\alpha$ - and $\gamma-$ tocopherols in atlantic salmon (Salmo salar) tissues. Lipids. 33(7):697-704. 
Poston HA, and Livingston DL. 1969. Effects of massive doses of dietary vitamin E on fingerling brook trout. In: Fish. Res. Bull.No. 33: 9-12. Albany, N.Y.: State of New York Conservation Department.

Poston HA, Combs GF Jr, and Leibovitz L.1976. Vitamin E and selenium interrelations in the diets of Atlantic salmon (Salmo salar): gross, histological and biochemical deficiency signs. J. Nutr. 106:892.

Robbins FM, Walker JE, Cohen SH and Chaterjee S. 1979. Action of proteolytic enzymes on bovine myofibrils. J. Food Sci. 44:1672.

Rosinvalli LJ, and Charm SE. 1975. Spoilage and shelf-life prediction of refrigerated fish. Marine Fisheries Review. 37: 32-34.

Rodriguez CJ, Besteiro I, and Pascual C. 1999. Biochemical changes in fresh water rainbow trout (Oncorchynchus mykiss) during chilled storage. J. Sci. Food Agric. 79: 1473-1480.

Rodriguez-G M-N, Sanz JJ, Santos JA, Otero A, and Lopez-G M-L. 2001. Bacteriological quality of aquacultured fresh water fish portions in prepackaged trays stored at $3^{\circ} \mathrm{C}$. J. Food Prot. 64(9): $1399-1404$.

Ryder JM, Buisson DH, Scott DN, and Fletcher GC. 1984. Storage of New Zealand Jack mackerel (Trachurus novaezelandiae) in ice: chemical, microbiological and sensory assessment.J Food Sci 49:1453-1456, 1477.

Sato, K., C. Ohashi, K. Ohtsuki, and M. Kawabata. 1991. Type V collagen in trout (Salmo gairdneri) muscle and its solubility change during chilled storage of muscle. J. Agric. Food Chem. 39:1222-1225.

Scott DN, Fletcher GC, Hogg MC, and Ryder JM. 1986. Comparison of whole with headed and gutted orange roughy stored in ice: sensory, microbiology and chemical assessment. J. Food Sci. 51(1): 79.

Scott DN, Porter RW, Kudo G, Miller R, and Koury B. 1988. Effect of freezing and frozen storage of Alaska pollack on the chemical and gel-forming properties of surimi. J. Food Sci. 50:723-726.

Shewan JM. 1962. The bacteriology of fresh and spoiling fish and some related chemical changes. In: Hawthorn J \& and Leitch JM, editors. Recent advances in food science. 1:167-193.

Shewan JM. 1977. The bacteriology of fresh and spoiling fish and the biochemical changes induced by bacterial action. In: Proceedings of the Conference on Handling, Processing and Marketing of Tropical Fish. Tropical Products Institute, London. 51-66. 
Shirai T, Fuke S, Yamaguchi K and Konosu S. 1988. Nucleotides, quaternary ammonium bases and related compounds in the raw and heated muscle of salmon. Nip Sui Gak 54:1199-1207.

Simeonidou S, Govaris K, and Vareltzis K. 1998. Quality assessment of seven Mediterranean fish species during storage on ice. Food Res Int 30(7):479-484.

Sikorski ZE, and Pan BS. 1994. The involvement of proteins and nonprotein nitrogen in postmortem changes in seafoods. In: Sikorski ZE, Pan BS, Shahidi F, editors. Seafood proteins. New York: Chapman and Hall. p71-83.

Stansby ME, and Olcott HS. 1963. Chapter 26. Composition of fish. In indusrial fishery technology. New york: Reinhold Pub.

Stephan G, Guillaume J, and Lamour F. 1995. Lipid peroxidation in turbot (Scophthalmus maximus) tissue: effect of dietary vitamin $\mathrm{E}$ and dietary $\mathrm{n}-6$ or $\mathrm{n}-3$ polyunsaturated fatty acid. Aquaculture. 130:251-268.

Su YC, and Morrissey MT. 2003. Reducing levels of Listeria monocytogenes contamination on raw salmon with acidified sodium chlorite. J. Food Prot. 66(5): 812818.

Suyama M, and Konosu A. 1987. Postmortem changes of fish and shellfish, In Marine Food science (Suison shokuhin-Gaku). Koseisha, Koseikaku. Tokoyo. 95.

Thomson AB, McGill AS, Murray J, Hardy R, and Howgate PF. 1980. Low molecular weight compounds: constituents of cooked haddock (Gadus aeglefinus) and the influence of these on flavor. In: Connell JJ, editor. Advances in fish science and technology. Surrey, England: Fishing News Books. p 484-488.

Venugopal V, and Shahidi F. 1996. Structure and composition of fish muscle. Food Rev Int.12(2):175-197.

Waagbø R, Sandnes K, Torrissen OJ, Sandvin A, and Lie Ø. 1993. Chemical and sensory evaluation of fillets from Atlantic salmon (Salmo salar) fed three different levels of N-3 polyunsaturated fatty acids at two levels of vitamin E. Food Chem. 46:361-366.

Ward DR, and Baj NJ. 1988. Factors affecting microbiological quality of sea foods. Food Technol. 42:85.

Warf CC Jr, and Kemp GK. 2001. Chemistry and mode of action of acidified sodium chlorite [abstract]. In: IFT Annual Meeting Abstracts; 2001; New Orleans, La. Chicago III.: Institute of Food Technologists. Abstract nr 91-1. 
Watanabe T, Takeuchi T, and Wada M.1981a. Dietary lipid levels and $\alpha$-tocopherol requirement of carp. Bull. Jpn. Soc. Sci. Fish. 47:1585-1590.

Watanabe T, Takeuchi T, Wada M, and Vehara R.1981b. The relationship between dietary lipid levels and $\alpha$-tocopherol requirement of rainbow trout. Bull. Jpn. Soc. Sci. Fish. 47:1463-1471.

Watanabe T. 1990. roles of vitamin E in aquaculture. Yukagaku. 39:299-306.

Xiong YL. 1994. Myofibrillar protein from different muscle fiber types: Implications of bio-chemical and functional properties in meat processing. Crit Rev Food Sci Nutr 34(3):293-320.

Zhang Y, Turunen M, and Applekvist El. 1996. Restricted uptake of dietary coenzyme $Q$ is in contrast to the unrestricted uptake of $\alpha$-tocopherol into rat organs and cells. J. Nutr. 126 (9):2089-2097.

Zhang Y, Lu H, and Levin EL. 2003. Enhanced storage-life of fresh haddock fillets with stabilized sodium chlorite in ice. Food Microbiology. 20:87-90. 
CHAPTER 1

TIME AND TEMPERATURE AFFECT STORAGE STABILITY OF RAINBOW TROUT (Oncorhynchus mykiss) FILLETS 


\begin{abstract}
Fresh rainbow trout, Oncorhynchus mykiss, fillets were placed on styrofoam trays and over-wrapped with polyvinyl chloride (PVC) film. Fillets were stored at 0 and $4.5^{\circ} \mathrm{C}$ for $0,3,6$ and $9 \mathrm{~d}$. Psychrotrophic counts, color and TBARS of raw fillets and shear force of cooked fillets were determined at $0 \mathrm{~d}$ and through $9 \mathrm{~d}$ of storage. A two by four factorial, randomized complete block design was used. The experiment was replicated three times. Psychrotrophic counts increased as temperature and storage time increased. The $\mathrm{a}^{*}$-values increased to $3 \mathrm{~d}$, and this value was maintained through $9 \mathrm{~d}$ storage. For $\mathrm{L}^{*}$-values, there was a temperature by time interaction $(p<0.05)$. Fillets stored at $0^{\circ} \mathrm{C}$ for 0 and $3 \mathrm{~d}$ were darker compared to all fillets stored at $4.5^{\circ} \mathrm{C}$ and fillets stored at $0^{\circ} \mathrm{C}$ for 6 and 9 days. Fillet $b^{*}$-values were higher at $4.5^{\circ} \mathrm{C}$ than at $0^{\circ} \mathrm{C}$. Storage time did not affect $b^{*}$-value. Fillets stored at $0^{\circ} \mathrm{C}$ had a higher $\mathrm{pH}$ than fillets stored at $4.5^{\circ} \mathrm{C}$; $\mathrm{pH}$ increased during storage $(p<0.05)$. Storage temperature did not affect TBARS, but by $3 \mathrm{~d}$ storage, TBARS level were higher than at $0 \mathrm{~d}$ storage; values decreased through $9 \mathrm{~d}$ storage. Kramer shear force was not affected $(p>0.05)$ by storage temperature. However, response peaked at day 6 of storage $(199.0 \mathrm{~g} / \mathrm{g})$ and declined to $175.9 \mathrm{~g} / \mathrm{g}$ by day 9 . Keywords: rainbow trout, storage time, storage temperature
\end{abstract}




\section{INTRODUCTION}

The growing demand for fresh fish has necessitated development of new technologies to improve storage stability. After harvest, autolysis and bacterial growth lead to a progressive decline in fish quality (Haard 1992). Freshness of fish is lost even before spoilage occurs (Ehira and Uchiyama 1986). Loss of freshness is mainly due to biochemical and enzymatic changes; whereas, spoilage is due to bacterial action (Vazquez-Orbitz and others 1997). During refrigeration or iced storage, fish harvested from cold waters spoil much quicker than the fish from warm waters due to high loads of psychrotrophic, Gram-negative spoilage bacteria, that decrease the lag time before growth and lead to subsequent spoilage (Liston 1980; Ward and Baj 1988).

Undesirable, deteriorative quality changes continue during processing and storage and reduce shelf life of fish products. Storage temperature is an important factor affecting freshness and quality (Singholt and others 1997). Temperature abuse increases the rate of microbial growth (FAO 1995), and it causes discoloration in fish by increasing the sensitivity of myoglobin to autoxidation (Liningston and Brown 1981). Storage time on ice is an important factor affecting texture of rainbow trout fillets (Færgemand and others 1995). Because rainbow trout fillets are highly perishable, establishing storage limits for fresh trout fillets will facilitate development of appropriate interventions to optimize quality. Hence, the objective of this study was to obtain basic information about the storage stability of rainbow trout fillets stored at different temperatures and times. 


\section{MATERIALS AND METHODS}

\section{Fish Fillet preparation}

Rainbow trout (Oncorhynchus mykiss) were obtained from The Conservation Funds, Freshwater Institute. Fish were packed in ice and transported to West Virginia University within $3 \mathrm{~h}$ of harvest. Gutting and filleting were performed manually, and fish were subsequently washed in a dilute salt / ice slurry. Fillets were drained for approximately $14-16 \mathrm{~h}$ at $0^{\circ} \mathrm{C}$. Subsequently, fresh fillets were aerobically packed on styrofoam trays and over-wrapped with polyvinyl chloride (PVC) film. Fillets were stored in the dark at 0 and $4^{\circ} \mathrm{C}$ for $0,3,6$, and 9 days.

\section{Sample processing}

On one half of the fillet, a $3.81 \mathrm{~cm}$ dia core was removed at the cranial end; the skin remained on the core for microbial analysis. The remainder of the fillet was skinned, divided into small pieces (excluding belly flap), frozen in liquid $N_{2}$, and powdered in a commercial blender (Waring, New Hartford, Conn., U.S.A) for 2 to 3 min. Powdered samples were used to determine thiobarbituric acid reactive substances (TBARS) and $\mathrm{pH}$. The alternate side of the fillet was cooked to an internal temperature of $65^{\circ} \mathrm{C}$ to measure shear force. Color measurements were recorded prior to cooking this portion of the fillet.

\section{Experimental analyses}

$\mathrm{pH}$ : Five grams of powdered sample was mixed with $50 \mathrm{~mL}$ of deionized distilled water to determine $\mathrm{pH}$. The $\mathrm{pH}$ of the slurry was measured using a $\mathrm{pH} /$ ion analyzer (Model 350, Corning Inc.; Corning NY, USA) with a general purpose combination probe. 
Lipid oxidation: Lipid oxidation in the powdered samples of all fillets was measured by the 2-thiobarbituric acid method (Yu and Sinnhuber 1957). Absorbance was read at $535 \mathrm{~nm}$ using a Spectronic 20D spectrophotometer (Milton Roy, NJ, U.S.A). Results were reported as mg malonaldehyde (MDA) per kg of sample.

Psychrotrophic counts: Surface counts of psychrotrophic bacteria were determined on all fillets. A $11.4 \mathrm{~cm}^{2}$ core with the skin attached was removed from the cranial end of the fillet. The cored sample was blended with $25 \mathrm{ml}$ of $0.1 \%$ peptone water in a Stomacher 400 blender (Tekmar, Cincinnati, Ohio, U.S.A) for $30 \mathrm{sec}$. A $1 \mathrm{~mL}$ aliquot of the homogenate was serially diluted with peptone water and each diluent was spread plated on duplicate plates of plate count agar (Swanson and others 1992). At day 0 , a $0.1 \mathrm{~mL}$ aliquot was directly spread on the plates. The initial ratio of sample to diluent was $0.912 \mathrm{~cm}^{2} / \mathrm{mL}$. Inverted plates were incubated at $25^{\circ} \mathrm{C}$ for $24 \mathrm{~h}$. Counts were reported as $\log _{10} \mathrm{CFU} / \mathrm{cm}^{2}$.

Color: Fillet color was measured with a Minolta chromameter (Model CR-300, Minolta Camera Co. Ltd.; Osaka, Japan) calibrated using a standard white plate No.21333180 (CIE L* 93.1; $\left.a^{*} 0.3135 ; b^{*} 0.3198\right) . L^{*}$ (Lightness), $a^{*}$ (redness), and $b^{*}$ (yellowness) values were measured at the cranial or caudal half of the right or left side of the fillet. The average of these two values was used as the observation for that fillet.

Texture characteristics: A $3 \times 8 \mathrm{~cm}$ strip was removed from the cranial portion of the fillet above the lateral line. This portion of the fillet was placed in the sample holder with the skin side up, and shear force was measured with a 5-blade Kramer shear attachment of Texture Analyzer (Model TA-HDi, Texture Technologies Corp.; 
Scarsdale, NY) at a cross head speed of $125 \mathrm{~mm} / \mathrm{min}$. Shear force was expressed as $\mathrm{g}$ force/g of sample.

\section{Experimental design}

A two by four factorial, randomized complete block design with day as block was used (Appendix 1). Treatment combinations of two temperatures $\left(0\right.$ and $\left.4^{\circ} \mathrm{C}\right)$ and four storage times $(0,3,6$, and 9 days) were replicated three times on separate days. Data were analyzed using the General Linear Model (GLM) procedure of SAS (SAS Institute, Inc., 1999) to establish main and interaction effects. Significance was determined at $p<0.05$.

\section{RESULTS AND DISCUSSION}

$\mathrm{pH}$

Fillets stored at $0^{\circ} \mathrm{C}$ had higher $\mathrm{pH}(\mathrm{p}<0.05)$ than fillets stored at $4.5^{\circ} \mathrm{C}$ (Table 1$)$; Fillet $\mathrm{pH}$ increased $(\mathrm{p}<0.05)$ to 3 days of storage and thereafter declined to levels higher than values observed at $0 \mathrm{~d}$ (Table 2). Rodriguez and others (2001) reported an increase in $\mathrm{pH}$ from 6.42 to 6.61 in rainbow trout fillets stored at $3^{\circ} \mathrm{C}$ for 10 days. The increase in $\mathrm{pH}$ during storage may be due to production of $\mathrm{NH}_{3}$ and amines by bacterial action during storage.

\section{Microbial analysis}

Psychrotrophic counts increased as storage temperature and time increased $(p<0.05)$ (Figure 1). Psychrotrophic bacteria grew more quickly on fillets stored at $4.5^{\circ} \mathrm{C}$ than at $0^{\circ} \mathrm{C}$, and significant differences were observed after 3 days of storage $(p<0.05)$. Seafood harvested form cold waters spoil quickly because of high loads of 
psychrotrophic, gram-negative spoilage bacteria that decrease the lag time and lead to spoilage during iced and refrigerated storage (Liston 1980; Ward and Baj1988). The counts increased from 2.7 to 6.0 and from 2.9 to $8.8 \log _{10} \mathrm{CFU} / \mathrm{cm}^{2}$ from 0 to $9 \mathrm{~d}$ for 0 and $4.5^{\circ} \mathrm{C}$ storage, respectively. Giminez and others (2002) reported that psychrotrophic counts in rainbow trout fillets stored at $1 \pm 1^{\circ} \mathrm{C}$ for 4 days exceeded the acceptable limit of $10^{7} \mathrm{CFU} / \mathrm{cm}^{2}$ where spoilage odors appear (Ordonez and others 2000). However, Rodriguez and others (2001) reported that rainbow trout fillets stored at $3^{\circ} \mathrm{C}$ were acceptable for 7 days when the mean aerobic counts $\left(30^{\circ} \mathrm{C}\right)$ increased from 5.27 to 8.76 .

\section{Lipid oxidation}

Temperature did not affect $(p>0.05)$ TBARS (Table 1$)$. But by $3 \mathrm{~d}$ storage, TBARS were higher than at $0 \mathrm{~d}$ storage and this level decreased through $9 \mathrm{~d}$ storage $(p<0.05)$ (Tables 2). Giminez and others (2002) also reported similar trends in overwrapped rainbow trout fillets stored at $1 \pm 1^{\circ} \mathrm{C}$ for 20 days. They suggested that the decline in TBARS during storage after an initial increase may be due to reaction of malonaldehyde with protein degradation products (Known and others 1965); interaction decreases availability of malonaldehyde for calorimetric determination.

\section{Color}

$L^{*}$ values were affected by the interaction of time and temperature $(p<0.05)$. Fillets stored at $0^{\circ} \mathrm{C}$ for 0 and $3 \mathrm{~d}$ were darker compared to all fillets stored at $4.5^{\circ} \mathrm{C}$ and fillets stored at $0^{\circ} \mathrm{C}$ for 6 and 9 days (Figure 2). The $a^{*}$-values increased to $3 \mathrm{~d}$, and this value was maintained through $9 \mathrm{~d}$ storage $(p<0.05)($ Table 2$)$. These values were not affected $(p>005)$ by storage temperature (Table 1$)$. Color $b^{*}$-values were 
higher for the fillets stored at $4.5^{\circ} \mathrm{C}$ than at the $0^{\circ} \mathrm{C}(\mathrm{p}<0.05)($ Table 1$)$. Storage time did not affect $b^{*}$-value $(p>0.05)$ (Table 2). Haard (1992) reported that the bright shiny appearance of skin becomes dull and faded; the translucent appearance of white muscle becomes opaque, and the bright hue of the dark muscle becomes dull or brown during chilled storage.

\section{Shear force}

Kramer shear force was not affected $(p>0.05)$ by storage temperature (Table 1$)$. However, this response peaked at day 6 of storage $(199.0 \mathrm{~g} / \mathrm{g})$ and declined by day 9 (175.9 g/g) (Table 2). Fægemand and others (1995) reported that rainbow trout fillets become soft on storage at $0^{\circ} \mathrm{C}$ for 10 days. 


\section{CONCLUSIONS}

Storage temperature and time affected fillet quality of rainbow trout. Fillets stored at $4.5^{\circ} \mathrm{C}$ had higher psychrotrophic counts than fillets stored at $0^{\circ} \mathrm{C}$. TBARS were significantly higher on day 3 of storage. These results suggest that fresh fillets over wrapped with PVC should not be stored more than 6 days at $0^{\circ} \mathrm{C}$ and 3 days at $4.5^{\circ} \mathrm{C}$. Basic information on the affect of storage temperature and time on storage stability of fresh rainbow trout would greatly benefit its processing and interventions to improve shelf life. 


\section{REFERENCES}

Ehira S, and Uchiyama H. 1986. Determination of fish freshness using the $k$ value and comments on some other biochemical changes in relation to freshness. In: Kramer DE, Liston J, editors. Seafood quality determination. Amsterdam. Elsevier science publishers. p185-207.

Færgemand J, RØnsholdt B, Alsted N, and BØrresen T. 1995. Fillet texture of rainbow trout as affected by feeding strategy, slaughtering procedure and storage post mortem. Wat. Sci. Technol. 31(10):225-231.

Food and Agriculture Organization of the United Nations. 1995. Postmortem changes in fish. In: Quality and quality changes in fresh fish. Chapter 5. FAO Fisheries technical paper - 348. Rome, Italy. Via internet. Accesed on July 152003.

Giminez B, Roncales R, and Beltran JA. 2002. Modified atmosphere packaging of filleted rainbow trout. J. Sci Food Agric. 82:1154-1159.

Haard NF. 1992. Technological aspects of extending prime quality of seafood: A review. Journal of Aquatic Food Product Technology 1(3/4):9-27.

Known TW, Menzel DB, and Olcott HS. 1965. Reactivity of malonaldehyde with food constituents. J. Food Sci. 30:808-813.

Liningston DJ, and Brown WD. 1981. The chemistry of myoglobin and its reactions. Food Technol. 35(5):244.

Liston J. 1980. Microbiology in fishery science. In: Connell JJ,editors. Advances in fishery science and technology. Farnham, England: Fishing News Books Ltd. p138157.

Ordonez JA, Lopez-Galvez DE, Fernandez M, Hierro E, and De la Hoz L. 2000. Microbial and physiochemical modifications of hake (Merluccius merluccius) steaks stored under carbon dioxide enriched atmospheres. J. Sci. Food Agric. 80: 18311840.

Rodriguez-G M-N, Sanz JJ, Santos JA, Otero A, and Lopez-G M-L. 2001. Bacteriological quality of aquacultured fresh water fish portions in prepackaged trays stored at $3^{\circ} \mathrm{C}$. J. Food Prot. 64(9): $1399-1404$.

SAS Institute Inc. 1999. SAS users guide: Basics version 8. Statistical Analysis System Institute Inc. Cary, NC.

Singholt T, Erikson U, Rustad T, Johansen S, Nordtvedt TS, and Seland A. 1997. Handling stress and storage temperature affect meat quality of farmed-raised atlantic salmon (Salmo salar). J. Food Sci. 62(4):898-905. 
Swanson KMJ, Busta FF, Peterson EH, and Johnson MG.1992. Colony count methods. In:Vanderzant C, Splittstoesser DN, editors. In:Compendium of methods for the microbiological examination of foods. 3rd edition. Washington DC: American Public Health Association. p 75-95.

Vázquez-Ortíz FA, Pacheco-Anguilar R, Lugo-Sánchez ME, and Villegas-Ozuna RE. 1997. Application of the freshness index (K value) for fresh fish to canned sardines from Northwestern Mexico. J. Food Comp. Anal. 10: 158-165.

Ward DR, and Baj NJ. 1988. Factors affecting microbiological quality of sea foods. Food Technol. 42:85.

Yu TC, and Sinnhuber RO. 1957. 2-thiobarbituric acid method for the measurement of rancidity in fishery products. Food Technol. 11(2):104-108. 
Table 1. Effect of storage temperature on muscle $\mathrm{pH}$, TBARS, $a^{*}$ value, $b^{*}$ value, and shear force.

\begin{tabular}{|l|c|c|}
\hline \multirow{2}{*}{ Trait } & \multicolumn{2}{|c|}{ Temperature, ${ }^{\circ} \mathrm{C}$} \\
\cline { 2 - 3 } & 0 & 4.5 \\
\hline Muscle $\mathrm{pH}$ & $6.32^{\mathrm{b}}$ & $6.26^{\mathrm{a}}$ \\
TBARS, MDA mg/kg & $3.2^{\mathrm{a}}$ & $3.3^{\mathrm{a}}$ \\
$\mathrm{b}^{*}$ value & $7.39^{\mathrm{a}}$ & $8.35^{\mathrm{b}}$ \\
$\mathrm{a}^{*}$ value & $0.62^{\mathrm{a}}$ & $0.56^{\mathrm{a}}$ \\
Shear force, g/g & $176.54^{\mathrm{a}}$ & $184.92^{\mathrm{a}}$ \\
\hline
\end{tabular}

${ }^{a b}$ Means within a row with different superscripts are different $(p<0.05)$. 
Table 2. Effect of storage time on muscle $\mathrm{pH}, \mathrm{TBARS}, \mathrm{a}^{*}$ value, $b^{*}$ value, and shear force.

\begin{tabular}{|l|c|c|c|c|}
\hline \multirow{2}{*}{ Trait } & \multicolumn{4}{|c|}{ Storage time, day } \\
\cline { 2 - 5 } & 0 & 3 & 6 & 9 \\
\hline Muscle $\mathrm{pH}$ & $6.18^{\mathrm{a}}$ & $6.37^{\mathrm{c}}$ & $6.31^{\mathrm{bc}}$ & $6.29^{\mathrm{b}}$ \\
TBARS, MDA mg/kg & $0.8^{\mathrm{a}}$ & $4.3^{\mathrm{b}}$ & $4.2^{\mathrm{b}}$ & $3.7^{\mathrm{b}}$ \\
$\mathrm{b}^{*}$ value & $7.78^{\mathrm{a}}$ & $7.39^{\mathrm{a}}$ & $8.59^{\mathrm{a}}$ & $7.70^{\mathrm{a}}$ \\
$\mathrm{a}^{*}$ value & $0.09^{\mathrm{a}}$ & $0.64^{\mathrm{b}}$ & $0.85^{\mathrm{b}}$ & $0.80^{\mathrm{b}}$ \\
Shear force, g/g & $172.84^{\mathrm{a}}$ & $175.13^{\mathrm{a}}$ & $199.03^{\mathrm{b}}$ & $175.93^{\mathrm{a}}$ \\
\hline
\end{tabular}

${ }^{a b c}$ Means within a row with different superscripts are different $(p<0.05)$. 


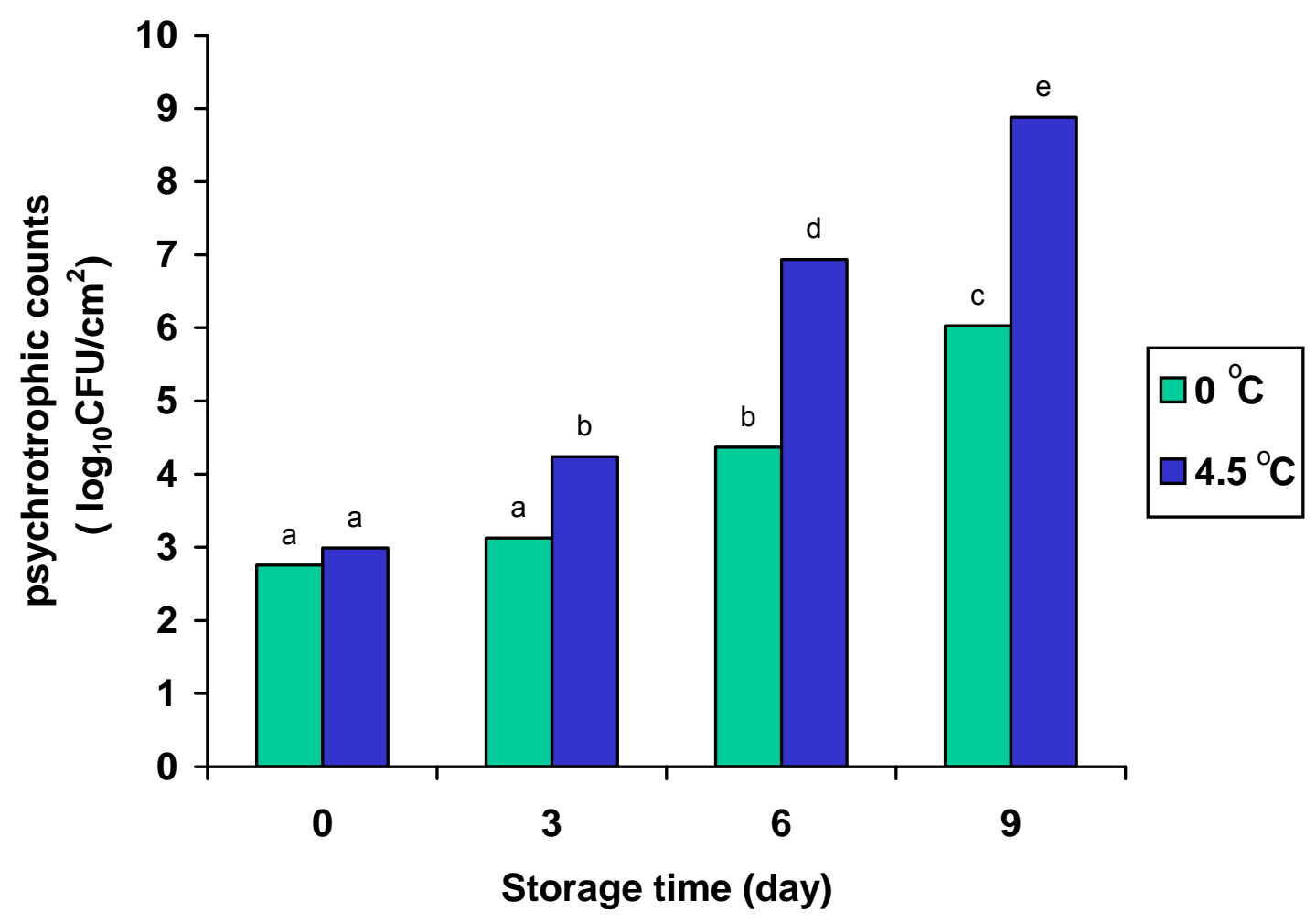

Figure 1. Effect of storage time and temperature on psychrotrophic counts. ${ }^{\text {abcde }}$ Bars with different superscripts are different $(p<0.05)$. 


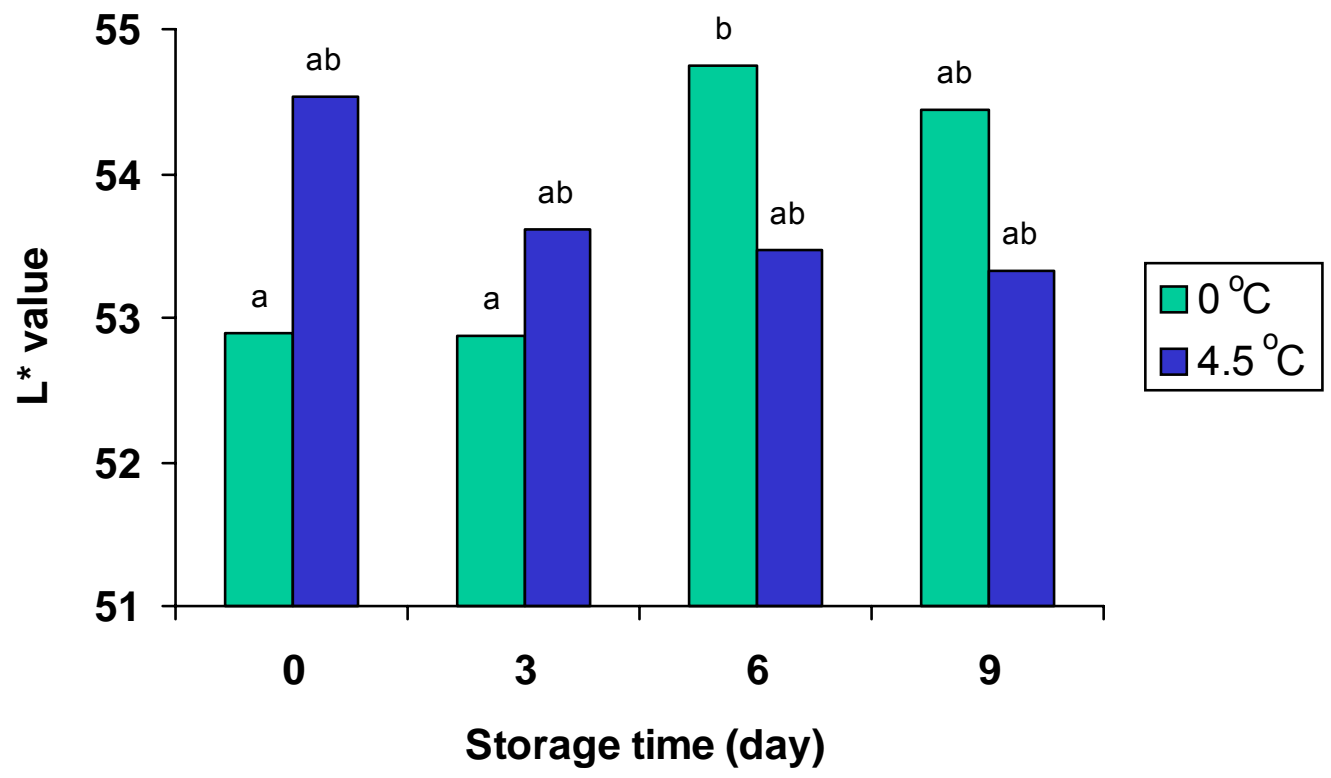

Figure 2. Effect of storage time and temperature on $L^{*}$ value.

${ }^{a b}$ Bars with different superscripts are different $(p<0.05)$. 
APPENDICES 


\section{APPENDIX}

\section{Statistical program for all responses}

option LS=80 pagesize $=\mathbf{6 0}$ nonumber;

title;

data response; input wk $\$$ tank $\$$ day $\$$ temp $\$$ response;

cards;

proc print;

proc glm; classes wk day temp response;

model response=wk day temp temp*day;

Ismeans day temp temp*day/pdiff;

run; 


\section{CHAPTER 2 \\ EFFECT OF VITAMIN E SUPPLEMENTATION ON STORAGE STABILITY OF RAINBOW TROUT (Oncorhynchus mykiss) FILLETS}




\section{ABSTRACT}

Lipid oxidation decreases the storage quality of fresh and refrigerated seafood products. Rainbow trout were fed a commercial diet containing $47 \%$ crude protein, $18 \%$ crude fat, and $3 \%$ crude fiber or the commercial diet supplemented with vitamin E to an a-tocopherol concentration of $5000 \mathrm{mg} / \mathrm{kg}$ feed. Fish were fed for 9 weeks, and they were sampled for analyses at weeks $2,3,4,5,7$, and 9. A split-split plot arrangement of treatments in a $2 \times 6 \times 3$ factorial, completely randomized design was employed with three replications. At harvest, fish were mechanically stunned and immediately placed on ice in portable coolers for transport not exceeding $3 \mathrm{~h}$. Fish were manually eviscerated and filleted, and fillets were subsequently washed in a dilute salt / ice slurry. Fillets were placed on styrofoam trays and over-wrapped with polyvinyl chloride (PVC) film. Fillets were stored in the dark at $0^{\circ} \mathrm{C}$ for 0,7 , and 14 days. Fillets were analyzed for $\alpha$-tocopherol, lipid oxidation (TBARS), $\mathrm{pH}$, cook yield, shear force, psychrotrophic counts, moisture and fat. At week 9, fish in addition to the routine sample, were fasted for three days prior to slaughter and analyzed for $\alpha$-tocopherol, lipid oxidation, psychrotrophic counts, moisture and fat. Liver samples were obtained from all eighteen fish at the end of week 7 and 9 and also from fish fasted for three days prior to harvest at week 9 . At the end of 9 weeks, all fish were returned to the control feed for three weeks. At 12 weeks, six liver samples were collected for a-tocopherol determination. Vitamin E supplementation increased fillet $\alpha$-tocopherol content $(p<0.05)$. Storage time and fasting at 9 weeks had no affect on fillet vitamin $E$ content $(p>0.05)$. The liver accumulated more vitamin $E$ than muscle. At day 0 storage, TBARS value was not 
affected $(p>0.05)$ by vitamin E supplementation for any sampling week. Fasted fish generated less $(\mathrm{p}<0.05)$ TBARS compared to non-fasted fish. For fillet $\mathrm{pH}$, significant $(p<0.05)$ diet by storage time and duration of feeding by storage time interactions was observed. Color $L^{*}$ value was not affected by diet, duration of feeding or storage time interactions $(p>0.05)$. Fillets were least red at 14 days of storage $(p<0.05)$, and $b^{*}$ values increased $(p<0.05)$ with storage time. A significant $(p<0.05)$ duration of feeding by storage time interaction was observed for fat content, psychrotrophic counts, cook yield, and shear force. At day 0 , fasted fish had lower $(p<0.05)$ psychrotrophic counts than non-fasted fish. Following fasting, a slight increase in moisture and a decrease in fat content was observed on day 14 .

Keywords: vitamin E, lipid oxidation, storage stability 


\section{INTRODUCTION}

Fish lipids are rich in omega-3 fatty acids that are essential for human health. Lipid oxidation is a major concern in post-mortem processing and subsequent storage of fish. Lipid oxidation deteriorates quality of fish flesh, and thus marketability of fish products. Dietary fortification of fish feed with antioxidants increases tissue levels of antioxidants thereby reducing lipid oxidation (Frigg and others 1990; Baker and Davies 1996).

Vitamin $\mathrm{E}$ is a lipid soluble antioxidant. In vivo, and as a part of an antioxidant defense mechanism, vitamin $E$ protects the cells from reactive oxygen and free radicals generated by autoxidation of membrane lipids and proteins. Among the natural forms of vitamin $\mathrm{E}, \mathrm{d}$ - $\alpha$-tocopherol has the highest biopotency (NRC 1993) and it is usually supplemented as $\alpha$-tocopherol acetate in fish feed. Supplementation of $\alpha$-tocopherol has been effective in reducing lipid oxidation in rainbow trout fillets (Frigg and others 1990; Chaiyapechara and others 2003). Bai and Gatlin (1993) reported that muscle $\alpha$-tocopherol concentration, depends on dietary vitamin E concentration and duration of feeding. Prolonged feeding times did not increase vitamin E content in turbot (Scophthalmus maximus) (Ruff and others 2003). It is not clear if supplementation of finishing diets with extremely high doses of vitamin $\mathrm{E}$ for a short duration can improve the storage stability of fresh, refrigerated fillets. To characterize the impact of vitamin E supplementation on rainbow trout fillet quality, high doses of vitamin $\mathrm{E}$ were fed during the last 9 wk of production. 


\section{MATERIALS AND METHODS}

\section{Diet}

A Commercial fish diet (Melick Aquafeeds, Inc., Catawissa, PA, U.S.A) containing $47 \%$ crude protein, $18 \%$ crude fat, and $3 \%$ crude fiber served as the control (C). The vitamin E supplemented diet (VE) was prepared by enriching the control diet with Lutavit $E^{\circledR}$ (BASF, Mount Olive, NJ, U.S.A). Lutavit $E^{\circledR}$ contained vitamin $E$ acetate oil and silicon dioxide. This supplement was added to the control diet to provide $5000 \mathrm{mg} / \mathrm{kg}$ (IU/kg) of DL-alpha-tocopheryl acetate in the finished feed. Control and treated diets were prepared once at the initiation of the trial, and they were stored until the end of the study. Concentrations in the feed were monitored throughout the study (Appendix 1).

\section{Sampling of fish}

Initially, six fish from tanks assigned to control and vitamin E supplemented tanks were sampled to determine fish weight, and three fish were sampled to determine initial a-tocopherol concentration of the muscle. At 2, 3, 4, 5, 7, and 9 weeks of feeding, three fish were sampled from each of the control and vitamin E supplemented tanks. At the end of week 9, fish in addition to those sampled routinely, were fasted for three days prior to harvest, and they were sampled from both control and vitamin E tanks. At each week of sampling, fish were mechanically stunned and placed on ice in portable coolers for transport to West Virginia University for processing within $5 \mathrm{~h}$ of harvest. Fish were manually filleted and

eviscerated; fillets were subsequently washed in a dilute salt / ice slurry at approximately $17 \mathrm{mM}$. They were aerobically packed on styrofoam trays and over- 
wrapped with polyvinyl chloride (PVC) film. Fillets were stored in the absence of light at $0^{\circ} \mathrm{C}$ for 0,7 , and 14 days. At each sampling week by storage time combination, samples were analyzed for $\alpha$-tocopherol concentration, lipid oxidation, $\mathrm{pH}$, cook yield, shear force, psychrotrophic counts, moisture and fat. At week 9, fish fasted for three days prior to harvest were also analyzed for $\alpha$-tocopherol concentration, lipid oxidation, psychrotrophic counts, moisture and fat. Liver samples were obtained from all eighteen fish ( 3 fish $\times 2$ treatments $\times 3$ replications) at weeks 7 and 9 and also from fish fasted for three days prior to harvest at week 9 . At week 9, all fish were realimentated to the control feed for three weeks. After this 3 week period, twelve liver samples were collected for a-tocopherol analyses, six from treated tanks and six from control tanks.

\section{Sample preparation for chemical analyses}

On one side of the fillet, a $11.4 \mathrm{~cm}^{2}$ core was removed from the cranial portion of the fillet dorsal to the lateral line. The core contained muscle tissue and skin and it was used for determination of microbial levels on the fillet. The remainder of the fillet was skinned, cut into small pieces (excluding belly flap), frozen in liquid $\mathrm{N}_{2}$, and powdered in a commercial blender (Waring, New Hartford, Conn., U.S.A) for 2 to 3 min. Powdered samples were used to determine proximate composition, lipid oxidation, and a-tocopherol content. The alternate side of the fillet was cooked to an internal temperature of $65^{\circ} \mathrm{C}$. Upon cooling to room temperature, a portion of the dorsal musculature was removed to measure shear force and cook yield. Color was measured before the fillets were cooked. 


\section{Chemical and physical analysis}

Proximate composition: Proximate composition was determined according to AOAC procedures (1990).

pH: Sample $\mathrm{pH}$ was measured using a pH/ion analyzer 350 (Corning Inc.;Corning, NY) equipped with a flat surface combination probe. Fillet $\mathrm{pH}$ was measured at the cranial and caudal ends of the fillet. The average of the two values was recorded as fillet $\mathrm{pH}$.

a-tocopherol determination: Concentration of $\alpha$-tocopherol in the muscle, liver and feed was determined according to the simplified extraction procedure of Liu and others (1996). Fillet $\alpha$-tocopherol content was determined by extracting $1 \mathrm{~g}$ of muscle. Liver and feed $\alpha$-tocopherol was measured by extracting $0.25 \mathrm{~g}$ of sample. Vitamin E content was quantified using high-performance liquid chromatography (HPLC) with a Perkin Elmer series 4LC and a LC-75 spectrophotometric detector. Peak area of a-tocopherol was recorded and integrated using a Varian 4270 integrator. A Waters C-18 resolve silica, $5 \mu \mathrm{m}(39 \times 150 \mathrm{~mm})$ column, equipped with a guard column was used for all separations (Waters, Milford, MA, U.S.A). The mobile phase consisted of $96 \%$ iso-octane: $4 \%$ tethydrafuran (v/v) (Fishers Inc., PA, U.S.A) and was prepared fresh daily. D,L- a-tocopherol (Sigma-aldrich, St.Louis, MO, U.S.A), was used to establish the standard curve for quantification of $\alpha-$ tocopherol. 
Lipid oxidation: Lipid oxidation of the powdered samples was measured calorimetrically using 2-thiobarbituric acid (Yu and Sinnhuber 1957). Absorbance was read at $535 \mathrm{~nm}$ using a Spectronic 20D spectrophotometer (Milton Roy, NJ, U.S.A). Results were reported as mg malondialdehyde (MDA) per $\mathrm{kg}$ of sample.

Psychrotrophic counts: Psychrotrophic bacterial counts were determined on all fish samples at weeks $2,3,4,5,7$, and 9 of feeding on day 0,7 , and 14 of storage; nineweek fasted fish were evaluated on day 0 and 14 of storage. A $11.4 \mathrm{~cm}^{2}$ core, with skin attached, was removed from the cranial end of the fillet using a steel corer. The cored sample was blended with $25 \mathrm{~mL}$ of $0.1 \%$ peptone water in a Stomacher 400 blender (Tekmar, Cincinnati, Ohio, U.S.A) for $30 \mathrm{sec}$. A $1 \mathrm{~mL}$ aliquot of the homogenate was serially diluted with peptone water, and each diluent was spread plated on duplicate plates of plate count agar (Swanson and others 1992). At day 0, a $0.1 \mathrm{~mL}$ aliquot was directly spread on the plates. The initial ratio of sample to diluent was $0.912 \mathrm{~cm}^{2} / \mathrm{mL}$. Inverted plates were incubated at $25^{\circ} \mathrm{C}$ for $24 \mathrm{~h}$. Counts were reported as $\log _{10} \mathrm{CFU} / \mathrm{cm}^{2}$.

Color measurement: Fillet color was measured with a Minolta chromameter (Model CR-300, Minolta Camera Co Ltd.; Osaka, Japan). The instrument was calibrated using a standard white plate No.21333180 (CIE L* 93.1; $\left.a^{*} 0.3135 ; b^{*} 0.3198\right)$, and $L^{*}$ (lightness), $a^{*}$ (redness), and $b^{*}$ (yellowness) values were recorded at two randomly chosen locations on the cranial and caudal ends of the fillet. The mean of these two values was used as the color trait observation for that fillet.

Shear force and cook yield: Shear force was measured using a Texture Analyser (Model TA-HDi,Texture Technologies Corp.; Scarsdale, NY) with a 5-blade Kramer 
shear attachment at a cross head speed of $127 \mathrm{~mm} / \mathrm{min}$. A $3 \times 8 \mathrm{~cm}$ strip of the cooked fillet was removed from the dorsal musculature, skinned, weighed, and placed beneath the blades with the skin side up. Values were expressed as $\mathrm{g}$ force/g of sample. Cook yield was calculated by expressing cooked fillet weight as a percent of raw fillet weight.

\section{Experimental design and statistical analyses}

A split-split plot arrangement of treatments in a $2 \times 6 \times 3$ factorial, completely randomized design was conducted with three replications (Appendix 2). Factors A, $\mathrm{B}$, and $\mathrm{C}$ were diet, duration of feeding, and storage time, respectively. Dietary treatments (control and vitamin E) were the main plot, duration of feeding $(2,3,4,5$, 7 , and $9 \mathrm{wk})$ was the sub-plot, and storage time $(0,7$, and $14 \mathrm{~d})$ was the sub-sub plot. The General Linear Model (GLM) procedure of SAS (SAS Institute Inc., 1999) was used to analyze the data. PDIFF of the Ismeans procedure was used for separating means, and significance was established at $\mathrm{P}<0.05$.

Weight gain was analyzed as a $2 \times 6$ factorial, split-plot completely randomized design with dietary treatments as the main plot and duration of feeding as a sub-plot (Appendix 3). Moisture, fat and vitamin E content of the fasted fish (week 9) was analyzed as a $2 \times 2 \times 3$ factorial, split-split plot completely randomized design with dietary treatments as the main plot, fasting as a subplot (fasted and not fasted), and storage time as a sub-sub plot (Appendix 4). Psychrotrophic counts on the fasted fish (week 9) were analyzed as a $2 \times 2 \times 2$ factorial, split-split plot completely randomized design with dietary treatment as the main plot, fasting as a sub-plot and storage time ( 0 and $14 \mathrm{~d}$ ) as a sub-sub plot (Appendix 5). Following $14 \mathrm{~d}$ of 
refrigerated storage, lipid oxidation in fasted fish (week 9) was analyzed as a $2 \times 2$ factorial, split-plot completely randomized design with dietary treatments as the main plot and fasting as a sub-plot (Appendix 6).

\section{RESULTS AND DISCUSSION}

The mean, initial fish weight was $602.87 \mathrm{~g}$. Diet did not affect weight gain ( $p>0.05)$; however, weight increased to1143.15 g by week $9(p<0.05)$ (Table 1$)$.

\section{Vitamin E concentration}

The initial muscle a-tocopherol concentration was $33.0 \mathrm{mg} / \mathrm{kg}$, and vitamin $\mathrm{E}$ concentrations of the control and the vitamin E supplemented feed were 191.1 and $4926.1 \mathrm{mg} / \mathrm{kg}$, respectively. Vitamin E supplementation increased fillet $\alpha$-tocopherol concentration $(p<0.05)$ (Figure 1), and a significant $(p<0.05)$ diet by duration of feeding interaction was observed for this response. Fillet $\alpha$-tocopherol concentration of the supplemented fish increased $(p<0.05)$ with prolonged feeding of vitamin $E$; whereas vitamin content of control fillets did not change $(p>0.05)$ (Figure 1). Frigg and others (1990) observed a slight increase in fillet a-tocopherol concentration (15.0 to $19.7 \mathrm{mg} / \mathrm{kg}$ ) in rainbow trout fed $200 \mathrm{mg}$ of $\alpha$-tocopherol $/ \mathrm{kg}$ for 12 weeks. As

suggested by Ruff and others (2003), differences in rearing conditions, other dietary factors, method of analysis and size and age of fish could explain differences in vitamin $\mathrm{E}$ accumulation in muscle tissue.

Fasting fish for three days prior to harvest did not affect $(p>0.05) \alpha$-tocopherol concentration of the fillet. However, control fillets $(34.83 \mathrm{mg} / \mathrm{kg})$ contained less $(p<0.05)$ vitamin $E$ than the treated fillets $(165.24 \mathrm{mg} / \mathrm{kg})$. At the conclusion of the 
feeding trial (9 wk), livers of control and the vitamin E group contained $324.3 \mathrm{mg} / \mathrm{kg}$ and $15847 \mathrm{mg} / \mathrm{kg} \alpha$-tocopherol, respectively. After realimentation to the control feed for 3 weeks, vitamin E content of the livers was 479.0 and $6728.9 \mathrm{mg} / \mathrm{kg}$ in control and vitamin E supplemented group, respectively. Similar differences in incorporation of vitamin $\mathrm{E}$ in the muscle and liver of rainbow trout were reported by Frigg and others (1990) and Cowey and others (1981).

Hamre and Lie (1997) suggested that each organ may have a unique combination of mechanisms whereby they take up lipids and tocopherols from plasma. Catignani and Bieri (1977) reported the presence of an a-tocopherolbinding protein in rat liver; the protein $(30 \mathrm{kDa})$ exists uniquely in the hepatocytes of rat liver and regulates plasma tocopherol concentration by preferentially incorporating a-tocopherol into nascent, very low density lipoproteins (Dutta-Roy and others 1994). Parazo and others (1998) observed the importance of the liver in selecting a-tocopherol over $\gamma$-tocopherol. These authors suggested that eventhough the existence of a $30 \mathrm{kDa}$ protein has not been verified in fish, a protein analogous to the $30 \mathrm{kDa}$ a-tocopherol binding protein exists in Atlantic salmon liver because the liver appeared to be the most biased organ for accumulating a-tocopherol. These authors reported greater reduction of $\alpha$-tocopherol in the liver and muscle compared to kidney, serum, perivisceral fat, gills, brain, and testes during restricted intake of this vitamin.

\section{Lipid oxidation}

A significant $(p<0.05)$ diet by duration of feeding by storage time interaction was found for TBARS (Figure 2). On day 0, there were no differences in TBARS 
between the control and vitamin E supplemented fish within each week of feeding $(p>0.05)$. This response may be due to sufficient vitamin $E$ in control fillets to limit lipid oxidation or, under the conditions studied, little oxidation occurred. Beneficial affects of high doses of vitamin $\mathrm{E}$ are not evident, and this response may be due to a relatively low heme iron content and storage at low temperatures. The antioxidant effect of high doses of vitamin E is not challenged in this scenario as opposed to subjecting product to higher storage temperatures. Additionally, it is likely that following cooking of fillets a different response to vitamin E supplementation would be observed. Control fillets from fish harvested at week 4 showed a significant increase by day $7(p<0.05)$. By day 14 , lipid oxidation increased in control fillets processed at week 2 and 3 and also in vitamin E fillets at week $3(p<0.05)$. Chaiyapechara and others (2003) observed no significant differences in TBARS for rainbow trout fed $300 \mathrm{mg} / \mathrm{kg}$ and $1500 \mathrm{mg} / \mathrm{kg}$ of diet and stored for $0 \mathrm{~d}$ at $4^{\circ} \mathrm{C}$. However, after storage for 7 days at $4^{\circ} \mathrm{C}$ and at $-30^{\circ} \mathrm{C}$, TBARS were lower in fish fed either $15 \%$ or $30 \%$ lipid and vitamin E at $1500 \mathrm{mg} / \mathrm{kg}$ compared to the fish fed $30 \%$ lipid and vitamin E at $500 \mathrm{mg} / \mathrm{kg}$ diet. In turbot (Scophthalmus maximus) stored under retail conditions on ice for 9 days, dietary supplementation of vitamin $E$ at 500 and $1000 \mathrm{mg} / \mathrm{kg}$ decreased lipid oxidation compared to the low vitamin E diets (100 $\mathrm{mg} / \mathrm{kg}$ ). However, no significant differences were observed between high vitamin $\mathrm{E}$ diets. They also reported that by day 7 of storage, lipid oxidation plateaued for fish fed both high and low vitamin E diets. Lipid oxidation increased when the fish were fed more than 9 weeks, which was attributed to the slight increase in fat content after 15 weeks of feeding (Ruff and others 2003). Fish fasted for three days prior to 
harvest (9 weeks) produced less TBARS $(0.47 \mathrm{mg} / \mathrm{kg})$ than the non-fasted fish $(0.7$ $\mathrm{mg} / \mathrm{Kg})(\mathrm{p}<0.05)$.

$\mathrm{pH}$

Significant $(p<0.05)$ diet by storage time and duration of feeding by storage time interactions were observed for $\mathrm{pH}$ (Figure $3 \& 4$ ). At day $0, \mathrm{pH}$ of control fillets was slightly higher than the fillets of vitamin $E$ fish $(p<0.05)$. In control fillets, $\mathrm{pH}$ decreased with storage $(p<0.05)$. At day 0 , fillet $\mathrm{pH}$ was significantly higher $(\mathrm{p}<0.05)$ in fish fed for 2 weeks compared to all other fillets. At day 14, $\mathrm{pH}$ of fish fed for 2 weeks decreased $(p<0.05)$, whereas fish fed for 5 and 9 weeks showed an increase in $\mathrm{pH}(\mathrm{p}<0.05)$. Overall, $\mathrm{pH}$ fluctuated between 6.4-6.65. In turbot (Scophthalmus maximus), diet did not affect $\mathrm{pH}$. On day 0 of cold storage, $\mathrm{pH}$ was higher in fish fed for 15 weeks than in the fish fed for 9 or 12 weeks $(p<0.01)$, and on day 2 of weeks 12 and 15, fish had a higher $\mathrm{pH}$ than at 9 weeks (Ruff and others 2003). Foegeding and coworkers (1996) reported a range of 6.2-6.6 for ultimate $\mathrm{pH}$ of lean white fish. Nonetheless, these sporadic changes in $\mathrm{pH}$ may be of no practical significance because the magnitude of the changes is not enough to alter protein or microbiological quality.

\section{Color}

A significant $(p<0.05)$ diet by duration of feeding by storage time interaction was observed for $a^{*}$ value (Table 2 ). Fillets became less red on storage. Color $b^{*}$ values increased from 9.50 to 11.46 on storage $(p<0.05)$, indicating an increase in yellowness of fillets. $L^{*}$ values were not $(p>0.05)$ affected by diet, duration of feeding and storage time. Chaiyapechara and others (2003) reported that dietary 
vitamin $E$ had no effect on color of rainbow trout fed diets containing 300 or 1500 $\mathrm{mg} / \mathrm{kg}$ a-tocopherol. Robb and others (2000) observed an increase in lightness of rainbow trout fillets with lower post mortem $\mathrm{pH}$ and increased hue and chroma in the first four days of slaughter. Ruff and others (2002) reported a direct relationship between $b^{*}$ value and MDA values in Atlantic halibut and turbot. However, this relationship may not be readily applicable in the present study because MDA value did not vary much during storage. Albeit, subtle changes in fillet microstructure may affect the light reflecting properties of fillets during storage thereby affecting fillet color rendition.

\section{Cook yield and Shear force}

During storage, cook yield decreased for fillets fed for 2 and 5 weeks $(p<0.05)$ (Table 3). This decrease may be due to the loss of moisture during cooking. Diet differences were not significant for cook yield $(p>0.05)$. On days 14 and 7 shear force values were numerically higher for fish fed for 4 and 5 weeks, respectively compared to all other fillets. Foegding and others (1996) indicated that relative firmness of cooked fish meats is related primarly to muscle $\mathrm{pH}$ and water content. Ando and others (1992) observed softening of rainbow trout during chilled storage. However, in the present study, no clear patterns were observed for the effect of time and treatment on shear force (Table 3).

\section{Psychrotrophic counts}

Psychrotrophic counts increased with duration of feeding and storage time $(p<0.05)$ (Figure 5). Initial counts on fillets at week 7 and 9 were significantly higher than other fish $(p<0.05)$. This difference is not readily explainable, because all fish 
were grown and processed under controlled conditions throughout the study. Giminez and others (2002) reported that psychrotrophic counts in over-wrapped rainbow trout fillets exceeded $10^{7} \mathrm{CFU} / \mathrm{cm}^{2}$ after 6 days of storage at $1 \pm 1^{\circ} \mathrm{C}$. In our study, after 14 days of refrigerated storage the psychrotrophic counts ranged from $4.67-8.53 \log _{10} \mathrm{CFU} / \mathrm{cm}^{2}$. On week 9 , fasted fish had significantly lower counts than the non-fasted fish $(p<0.05)($ Table 4$)$. In fasted fish, the viscera might have been relatively clean at processing leading to less opportunity for contaminating the muscle during the filleting operation.

\section{Proximate composition}

An interaction of diet, duration of feeding and storage time $(p<0.05)$ was observed for moisture content of fillets (Table 5). On day 0 , with the exception of week 3 and 9 , control fillets had slightly higher moisture content than the vitamin $\mathrm{E}$ fillets. When fish were fasted at week 9 , moisture content increased in fasted and non-fasted groups during storage $(p<0.05)($ Table 6$)$. Fat content of fish fed 5 weeks decreased significantly on storage $(p<0.05)$ (Figure 6). After 9 weeks of feeding, fasted fish had higher fat content than non-fasted fish $(p<0.05)($ Table 6). Reuda and others (1998) reported an increase in lipid content after 7 days of fasting, but fasting for longer duration decreased the lipid content of red porgy (Pagrus Pagrus L.). Ruff and others (2003) reported that the moisture, fat, protein, and ash content in turbot (Scophthalmus maximus ) did not change significantly after feeding vitamin E for 15 weeks. 


\section{CONCLUSIONS}

Vitamin E supplementation increased fillet $\alpha$-tocopherol concentration. Lipid oxidation did not change significantly during storage or with supplementation of high doses of vitamin E. Color $b^{*}$ and psychrotrophic counts were not affected by $\alpha$ tocopherol content. Supplementation with vitamin E did not preserve fillet $a^{*}$ value with storage. Based on psychrotrophic counts, PVC over-wrapped fillets should not be stored for more than 7 days at $0^{\circ} \mathrm{C}$. Fasting of fish for three days prior to harvest reduced initial psychrotrophic counts, eventhough these differences were not significant after 14 days of storage at $0^{\circ} \mathrm{C}$. 


\section{REFERENCES}

Ando M, Toyohara H, and Sakaguchi M. 1992. Post-mortem tenderization of rainbow trout muscle caused by the disintegration of collagen fibers in the pericellular connective tissue. Nippon Suisan Gakkaishi. 58(3):567-570.

AOAC. 1990. Official Methods of Analysis. 15th ed. Washington, DC: Association of Official Analytical Chemists.

Bai SC, and Gatlin III DM. 1993. Dietary vitamin E concentration and duration of feeding affect tissue $\alpha$-tocopherol concentrations of channel catfish (Ictalurus punctatus). Aquaculture. 113: 129-135.

Baker RTM, and Davies SJ. 1996. Changes in tissue $\alpha$-tocopherol status and degree of lipid peroxidation with varying $\alpha$-tocopherol actetate inclusion in diets for the African catfish. Aquaculture Nutr. 2: 71-79.

Catignani GL, and Bieri JG. 1977. Rat liver $\alpha$-tocopherol binding protein. Biochim. Biophys. Acta. 497: 349-357.

Chaiyapechara S, Casten MT, Hardy RW, and Dong FM. 2003. Fish performance, fillet characteristics, and health assessment index of rainbow trout (Oncorhynchus mykiss) fed diets containing adequate and high concentrations of lipid and vitamin E. Aquaculture. 219:715-738.

Cowey CB, Andron JW, Walton MJ, Youngson A, and Knox D. 1981. Tissue distribution, uptake, and requirement for $\alpha$-tocopherol of rainbow trout (Salmo gairdneri) fed diets with a minimal content of unsaturated fatty acids. J. Nutr. 111:1556-1567.

Dutta-Roy AK, Gordon MJ, Campbell FM, Duthie GG, and James WPT. 1994. Vitamin $E$ requirements, transport, and metabolism: Role of $\alpha$-tocopherol binding proteins. J. Nutr. Biochem. 5:562-570.

Foegeding EA, Lanier TC, and Hultin HO. 1996. Characteristics of edible muscle tissues. In: O.Fennema, editor. Food Chemistry. New York:Marcel Dekker, Inc. p.915.

Frigg M, Prabucki AL, and Ruhdel EU. 1990. Effect of dietary vitamin E levels on oxidative stability of trout fillets. Aquaculture. 84:145-158.

Giminez B, Roncales R, and Beltran JA. 2002. Modified atmosphere packaging of filleted rainbow trout. J. Sci Food Agric. 82:1154-1159.

Hamre K, and Lie $\varnothing .1997$. Retained levels of dietary $\alpha-, \gamma-, \delta$ - tocopherol in tissues and body fluids of Atlantic salmon, Salmo salar . Aquaculture. Nutrition. 3:99-107. 
Liu Q, Scheller KK, and Schaefer DM. 1996. Technical note: A simplified procedure for vitamin E determination in beef muscle. J. Anim. Sci. 74: 2406-2410.

NRC (National Research Council) .1993. Nutrient Requirements of Fish. National Academy Press, Washington DC, USA. p 23-35.

Parazo MPM, Lall SP, Castell JD, and Ackman RG. 1998. Distribution of $\alpha$ - and $\gamma-$ tocopherols in atlantic salmon (Salmo salar) tissues. Lipids. 33(7):697-704.

Reuda FM, Martinez FJ, Zamaro S, Kentouri M, and Divanach P. 1998. Effect of fasting and refeeding on growth and body composition of red porgy, Pagrus pagrus L. Aquaculture Research. 29:447-452.

Robb DHF, Kestin SC, and Warris PD. 2000. Muscle activity at slaughter: I. Changes in flesh color and gaping in rainbow trout. Aquaculture. 182:261-269.

Ruff N, Fitzgerald RD, Cross TF, and Kerry JP. 2002. Comparitive composition and shelf-life of fillets of wild and cultured turbot (Scophthalmus maximus) and Atlantic halibut (Hippoglossus hippoglossus). Aquaculture International. 10: 241-256.

Ruff N, Fitzgerald RD, Cross TF, Hamre K, and Kerry JP. 2003. The effect of dietary vitamin $\mathrm{E}$ and $\mathrm{C}$ on market-size turbot (Scophthalmus maximus) fillet quality. Aquaculture Nutrition. 9: 91-103.

SAS Institute Inc. 1999. SAS users guide: Basics version 8. Statistical Analysis System Institute Inc. Cary, NC.

Swanson KMJ, Busta FF, Peterson EH, and Johnson MG. 1992. Colony count methods. In:Vanderzant C, Splittstoesser DN, editors. Compendium of Methods for the Microbiological Examination of Foods. 3rd edition. Washington D C: American Public Health Association. p 75-95.

Yu TC, and Sinnhuber RO. 1957. 2-thiobarbituric acid method for the measurement of rancidity in fishery products. Food Technol. 11(2):104-108. 
Table 1. Effect of duration of feeding on weight gain.

\begin{tabular}{|c|c|}
\hline $\begin{array}{c}\text { Duration of } \\
\text { feeding, wk }\end{array}$ & Weight gain, g \\
\hline 0 & $602.86^{\mathrm{a}}$ \\
2 & $675.08^{\mathrm{ab}}$ \\
3 & $759.47^{\mathrm{bc}}$ \\
4 & $805.94^{\mathrm{bc}}$ \\
5 & $885.64^{\mathrm{cd}}$ \\
7 & $981.69^{\mathrm{d}}$ \\
9 & $1143.15^{\mathrm{e}}$ \\
\hline
\end{tabular}

${ }^{\text {abcde }}$ Means with different superscripts are different $(p<0.05)$. 
Table 2. Effect of diet, duration of feeding, and storage time on $a^{*}$ value.

\begin{tabular}{|l|c|c|c|c|}
\hline \multirow{2}{*}{ Diet } & Duration of & \multicolumn{3}{|c|}{ Storage time, day } \\
\cline { 2 - 5 } & feeding, wk & 0 & 7 & 14 \\
\hline C & 2 & $-0.43^{\mathrm{cd}}$ & $-3.37^{\mathrm{a}}$ & $-3.30^{\mathrm{a}}$ \\
VE & 2 & $-1.11^{\mathrm{bd}}$ & $-1.98^{\mathrm{abc}}$ & $-2.39^{\mathrm{ab}}$ \\
VE & 3 & $-3.94^{\mathrm{a}}$ & $-3.00^{\mathrm{ab}}$ & $-0.09^{\mathrm{c}}$ \\
V & 3 & $-3.32^{\mathrm{a}}$ & $-1.44^{\mathrm{bc}}$ & $-0.02^{\mathrm{c}}$ \\
VE & 4 & $-3.28^{\mathrm{a}}$ & $-0.02^{\mathrm{b}}$ & $-2.33^{\mathrm{a}}$ \\
C & 4 & $-1.93^{\mathrm{a}}$ & $0.06^{\mathrm{b}}$ & $-2.55^{\mathrm{a}}$ \\
VE & 5 & $-0.65^{\mathrm{ab}}$ & $-2.09^{\mathrm{a}}$ & $1.24^{\mathrm{c}}$ \\
$\mathrm{C}$ & 5 & $0.81^{\mathrm{bc}}$ & $-1.11^{\mathrm{a}}$ & $0.77^{\mathrm{bc}}$ \\
VE & 7 & $-0.09^{\mathrm{b}}$ & $0.62^{\mathrm{b}}$ & $-3.22^{\mathrm{a}}$ \\
$\mathrm{C}$ & 7 & $-0.08^{\mathrm{b}}$ & $0.77^{\mathrm{b}}$ & $-2.64^{\mathrm{a}}$ \\
VE & 9 & $-2.33^{\mathrm{a}}$ & $-2.32^{\mathrm{a}}$ & $4.18^{\mathrm{b}}$ \\
\hline
\end{tabular}

${ }^{a b c d} \mathrm{C}$ and VE within each week with different superscripts are different $(p<0.05)$. 
Table 3. Effect of duration of feeding and storage time on cook yield and shear force.

\begin{tabular}{|c|c|c|c|c|c|c|}
\hline \multirow{2}{*}{$\begin{array}{c}\text { Duration } \\
\text { of } \\
\text { feeding, } \\
\text { wk }\end{array}$} & \multicolumn{3}{|c|}{ Cook yield } & \multicolumn{3}{|c|}{ Shear force } \\
\hline & \multicolumn{3}{|c|}{ Storage time, day } & \multicolumn{3}{|c|}{ Storage time, day } \\
\hline & 0 & 7 & 14 & 0 & 7 & 14 \\
\hline 2 & $81.66^{\mathrm{e}}$ & $75.35^{\mathrm{ab}}$ & $73.61^{a}$ & $178.67^{a}$ & $300.20^{\mathrm{bcd}}$ & $234.57^{\mathrm{abc}}$ \\
\hline 3 & $77.74^{\text {bc }}$ & $76.93^{\mathrm{ab}}$ & $76.17^{\mathrm{ab}}$ & $198.07^{a}$ & $286.24^{\mathrm{bcd}}$ & $244.83^{\mathrm{abc}}$ \\
\hline 4 & $75.84^{\mathrm{ab}}$ & $78.18^{\mathrm{bcd}}$ & $77.75^{\mathrm{bc}}$ & $370.77^{\text {def }}$ & $319.12^{\text {cde }}$ & $457.41^{f}$ \\
\hline 5 & $81.35^{\mathrm{de}}$ & $77.83^{b c}$ & $75.63^{\mathrm{ab}}$ & $178.57^{a}$ & $405.46^{\mathrm{ef}}$ & $317.23^{\mathrm{cd}}$ \\
\hline 7 & $83.12^{\mathrm{e}}$ & $77.82^{\mathrm{bc}}$ & $80.83^{\mathrm{ce}}$ & $225.89^{a b}$ & $279.52^{b c}$ & $218.28^{a b}$ \\
\hline 9 & $81.74^{\mathrm{e}}$ & $81.30^{\mathrm{de}}$ & $81.50^{\mathrm{de}}$ & $197.94^{a}$ & $220.53^{\mathrm{ab}}$ & $259.63^{\mathrm{abc}}$ \\
\hline
\end{tabular}

${ }^{\text {abcdef }}$ Means within each response with different superscripts are different $(p<0.05)$. 
Table 4. Effect of diet, fasting, and storage time on psychrotrophic counts.

\begin{tabular}{|l|c|c|c|c|}
\hline \multirow{2}{*}{ Diet } & \multicolumn{2}{|c|}{ Fasted fish } & \multicolumn{2}{c|}{ Non fasted fish } \\
\cline { 2 - 5 } & \multicolumn{2}{|c|}{ Storage time, day } & \multicolumn{2}{c|}{ Storage time, day } \\
& 0 & 14 & 0 & 14 \\
\hline C & $2.49^{\mathrm{a}}$ & $7.72^{\mathrm{c}}$ & $3.62^{\mathrm{b}}$ & $7.51^{\mathrm{c}}$ \\
VE & $2.29^{\mathrm{a}}$ & $7.63^{\mathrm{c}}$ & $4.02^{\mathrm{b}}$ & $8.23^{\mathrm{d}}$ \\
\hline
\end{tabular}

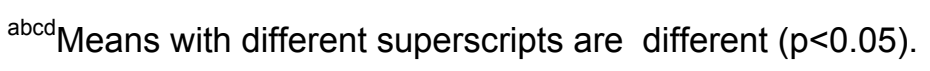


Table 5. Effect of diet, duration of feeding, and storage time on moisture content.

\begin{tabular}{|l|c|c|c|c|}
\hline \multirow{2}{*}{ Diet } & Duration of & \multicolumn{3}{|c|}{ Storage time, day } \\
\cline { 2 - 5 } feeding, wk & 0 & 7 & 14 \\
\hline C & 2 & $72.73^{\mathrm{a}}$ & $73.37^{\mathrm{ab}}$ & $74.64^{\mathrm{cd}}$ \\
VE & 2 & $73.91^{\mathrm{bc}}$ & $72.62^{\mathrm{a}}$ & $74.41^{\mathrm{bd}}$ \\
$\mathrm{C}$ & 3 & $73.45^{\mathrm{ab}}$ & $74.18^{\mathrm{b}}$ & $73.10^{\mathrm{a}}$ \\
VE & 3 & $72.60^{\mathrm{a}}$ & $74.38^{\mathrm{b}}$ & $72.56^{\mathrm{a}}$ \\
$\mathrm{C}$ & 4 & $74.00^{\mathrm{bc}}$ & $72.59^{\mathrm{a}}$ & $74.26^{\mathrm{c}}$ \\
VE & 4 & $72.64^{\mathrm{a}}$ & $73.12^{\mathrm{ab}}$ & $73.52^{\mathrm{ac}}$ \\
$\mathrm{C}$ & 5 & $72.23^{\mathrm{b}}$ & $73.65^{\mathrm{cde}}$ & $74.33^{\mathrm{e}}$ \\
VE & 5 & $70.96^{\mathrm{a}}$ & $72.93^{\mathrm{bd}}$ & $72.68^{\mathrm{bc}}$ \\
$\mathrm{C}$ & 7 & $73.03^{\mathrm{b}}$ & $73.74^{\mathrm{bc}}$ & $74.19^{\mathrm{c}}$ \\
VE & 7 & $70.66^{\mathrm{a}}$ & $72.91^{\mathrm{b}}$ & $74.21^{\mathrm{c}}$ \\
C & 9 & $72.18^{\mathrm{ab}}$ & $73.74^{\mathrm{cde}}$ & $73.22^{\mathrm{be}}$ \\
VE & 9 & $71.87^{\mathrm{a}}$ & $73.00^{\mathrm{bcd}}$ & $72.96^{\mathrm{bc}}$ \\
\hline
\end{tabular}

${ }^{\text {abcde }} \mathrm{C}$ and VE within each week with different superscripts are different $(p<0.05)$. 
Table 6. Effect of diet, fasting and storage time on moisture and fat content

\begin{tabular}{|l|l|c|c|c|c|c|c|}
\hline \multirow{2}{*}{ Diet } & \multirow{2}{*}{ Fasting } & \multicolumn{3}{|c|}{ Moisture, \% } & \multicolumn{3}{c|}{ Fat, \% } \\
\cline { 3 - 8 } & & \multicolumn{3}{|c}{ Storage time, day } & \multicolumn{3}{c|}{ Storage time, day } \\
& & 0 & 7 & 14 & 0 & 7 & 14 \\
\hline C & F & $70.97^{\mathrm{a}}$ & $72.92^{\mathrm{cde}}$ & $73.93^{\mathrm{f}}$ & $9.14^{\mathrm{f}}$ & $5.88^{\mathrm{bc}}$ & $3.78^{\mathrm{a}}$ \\
C & NF & $72.18^{\mathrm{bc}}$ & $73.74^{\mathrm{ef}}$ & $73.22^{\text {def }}$ & $5.34^{\mathrm{bc}}$ & $5.07^{\mathrm{ab}}$ & $5.11^{\mathrm{bc}}$ \\
VE & F & $71.18^{\mathrm{a}}$ & $71.54^{\mathrm{ab}}$ & $72.46^{\mathrm{bcd}}$ & $8.44^{\mathrm{ef}}$ & $7.57^{\mathrm{de}}$ & $4.55^{\mathrm{ab}}$ \\
VE & NF & $71.87^{\mathrm{ab}}$ & $73.00^{\text {cdef }}$ & $72.96^{\mathrm{cde}}$ & $5.78^{\mathrm{bc}}$ & $6.51^{\mathrm{cd}}$ & $4.74^{\mathrm{ab}}$ \\
\hline
\end{tabular}

${ }^{\text {abcdef }}$ Means within each response with different superscripts are different $(p<0.05)$. 


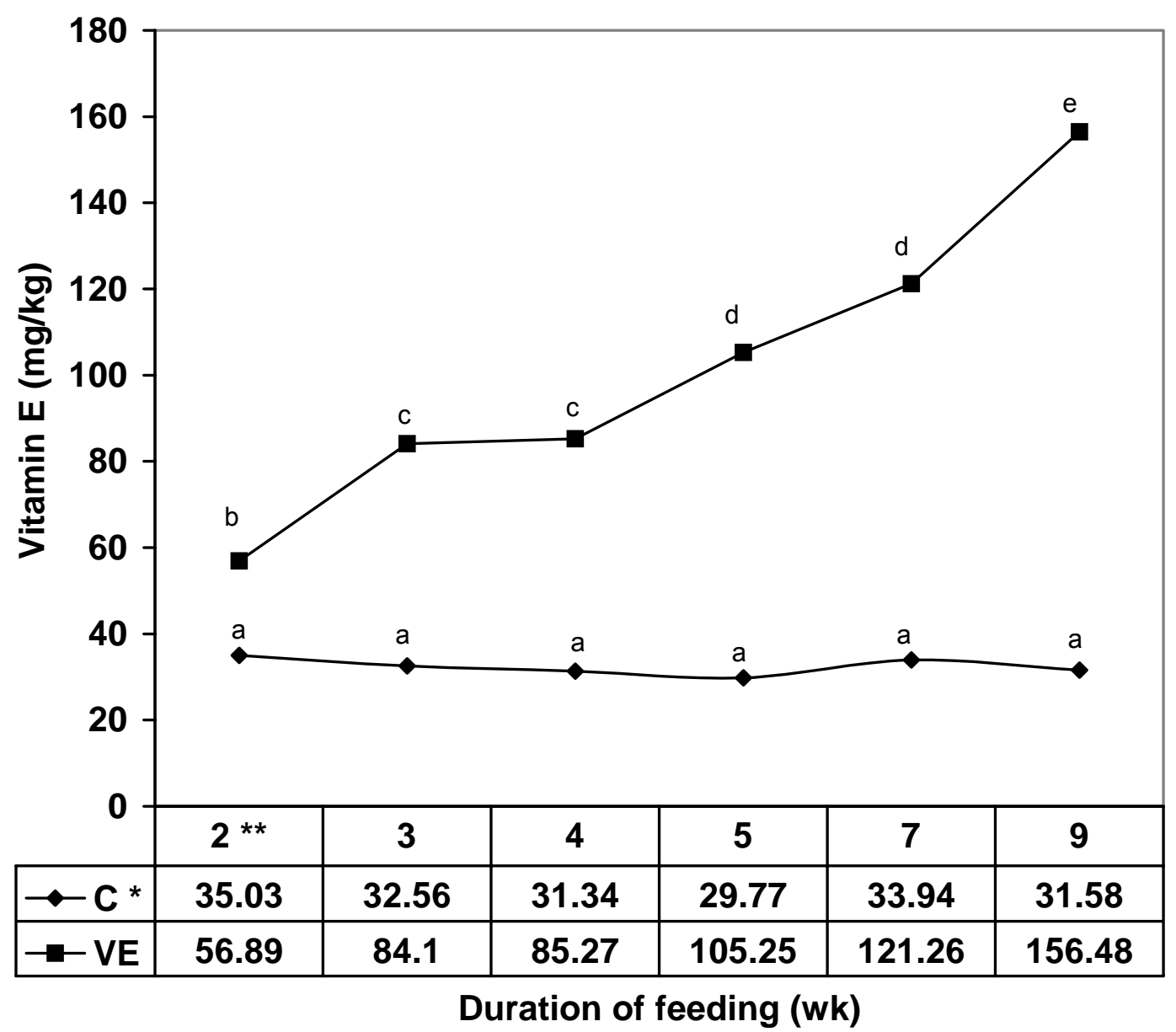

Figure 1. Effect of diet and duration of feeding on vitamin E content.

${ }^{\text {abcde }}$ points on the line with different superscripts are different $(p<0.05)$.

${ }^{*}$ C-control diet, and VE- 5000mg/kg diet.

${ }^{* *}$ Fish were sampled at $2,3,4,5,7$, and 9 weeks of feeding. 

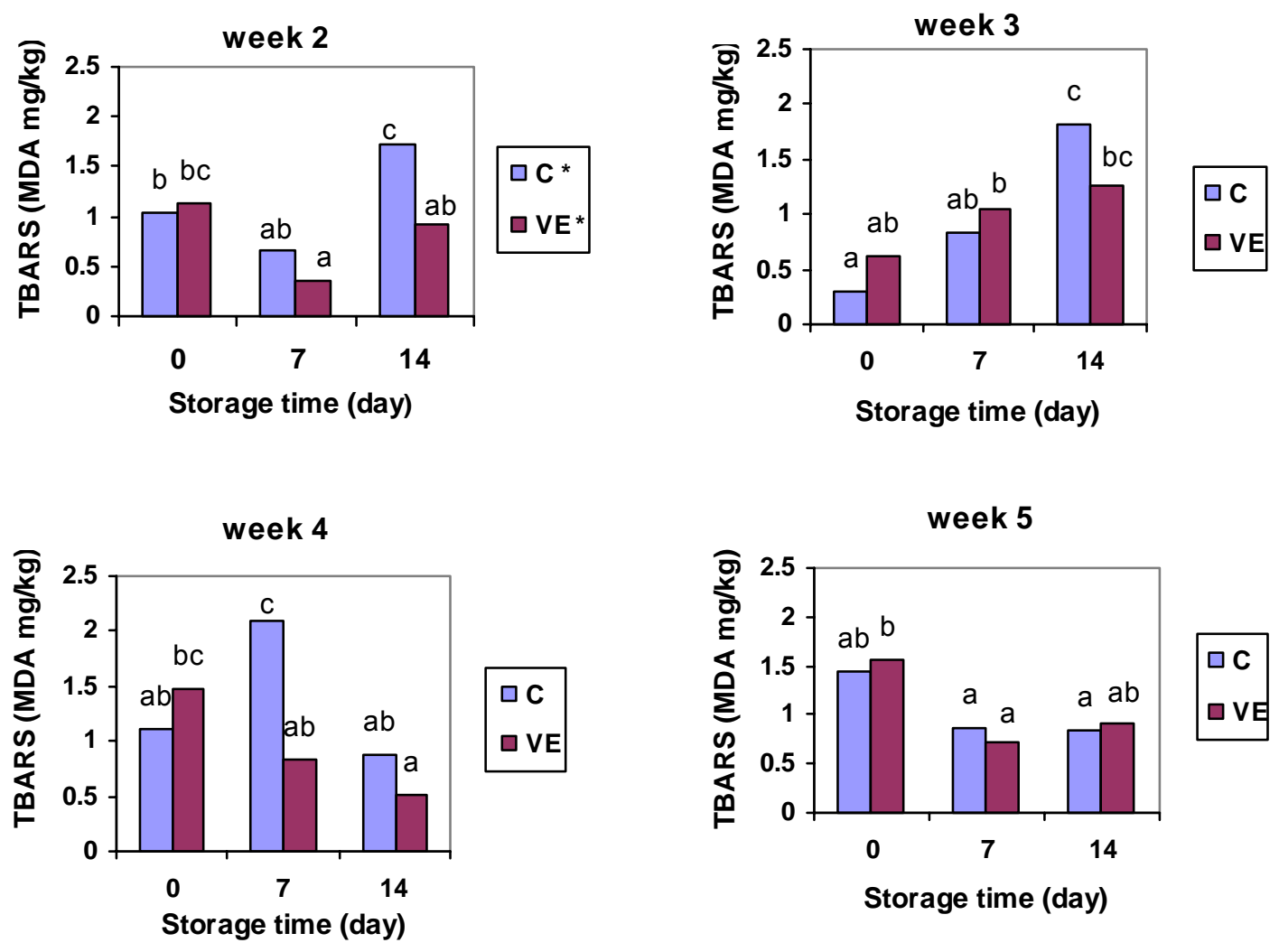

week 7
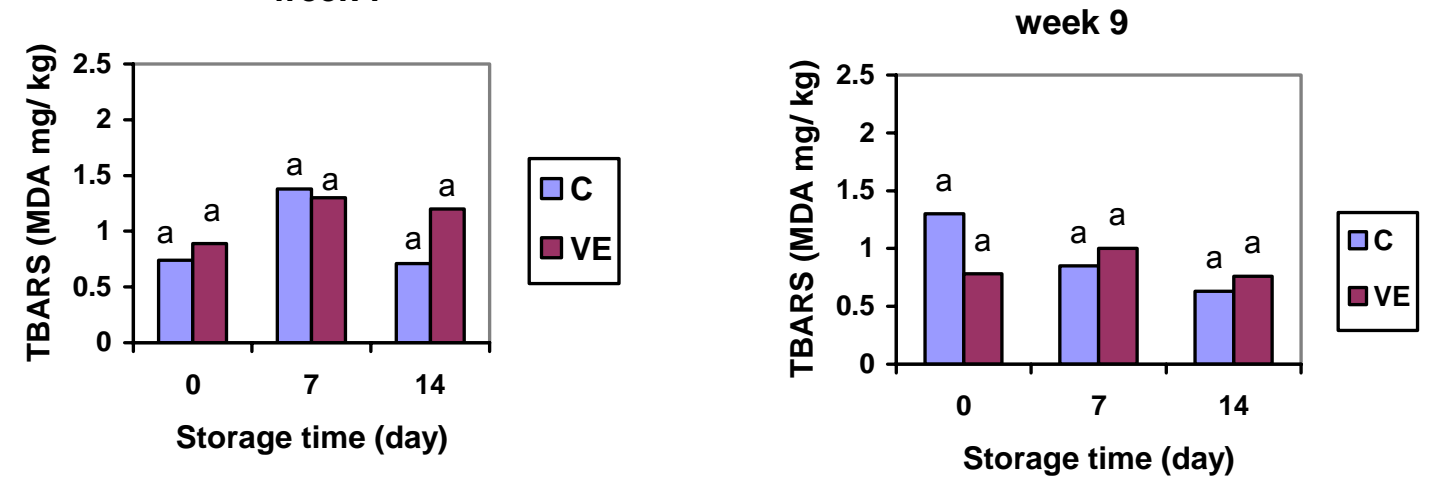

Figure 2. Effect of diet, duration of feeding and storage time on TBARS.

${ }^{a b c}$ Bars in each figure with different superscripts are different $(p<0.05)$.

${ }^{*} \mathrm{C}$-control diet, and VE- 5000mg/kg diet. 


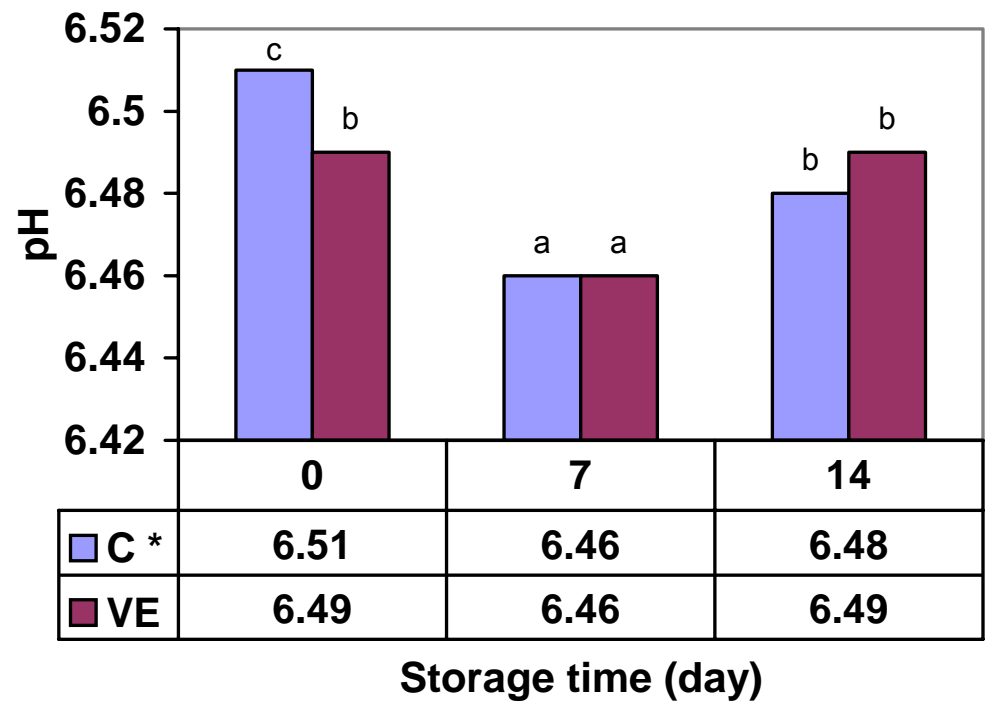

Figure 3. Effect of diet and storage time on pH.

${ }^{a b c}$ Bars with different superscripts are different $(p<0.05)$.

${ }^{*} \mathrm{C}$-control diet, and VE- 5000mg/kg diet. 


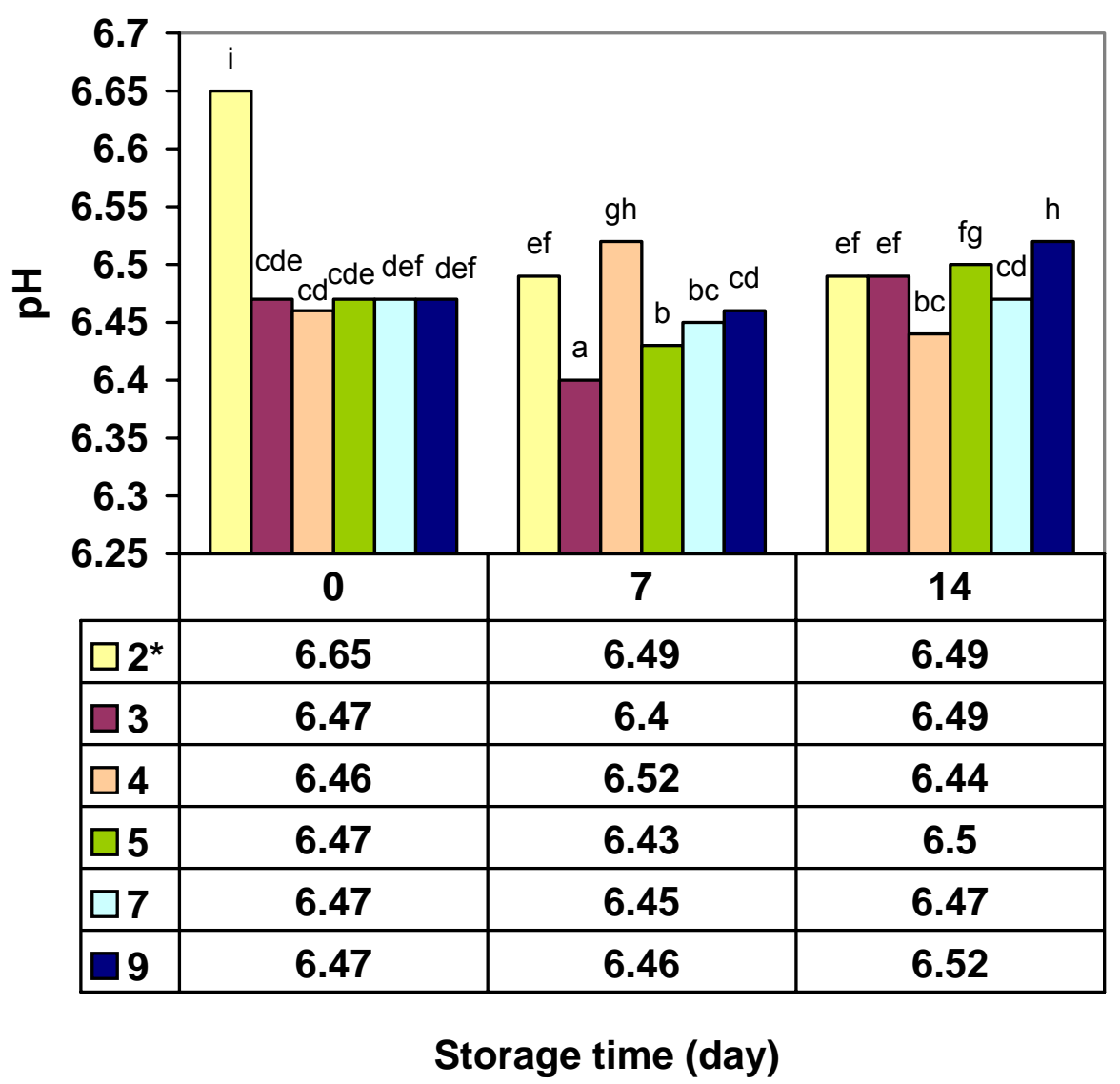

Figure 4. Effect of duration of feeding and storage time on $\mathrm{pH}$.

${ }^{\text {abcdefgh }}$ Bars with different superscripts are different $(p<0.05)$.

${ }^{*}$ Fish were sampled at $2,3,4,5,7$, and 9 weeks of feeding. 


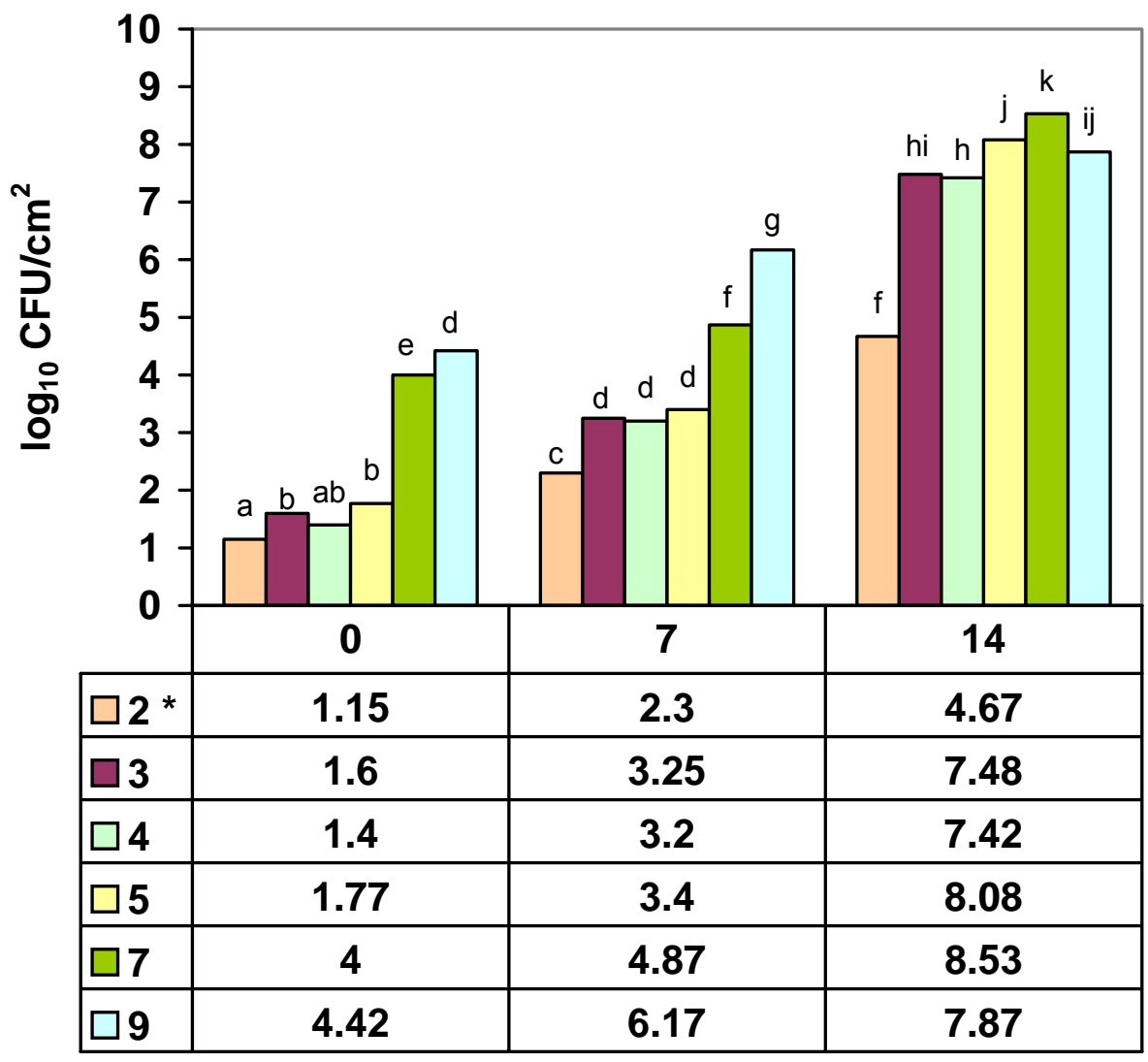

Storage time (day)

Figure 5. Effect of duration of feeding and storage time on psychrotrophic counts.

${ }^{\text {abcdefghijk }}$ Bars with different superscripts are different $(p<0.05)$.

${ }^{*}$ Fish were sampled at $2,3,4,5,7$, and 9 weeks of feeding. 


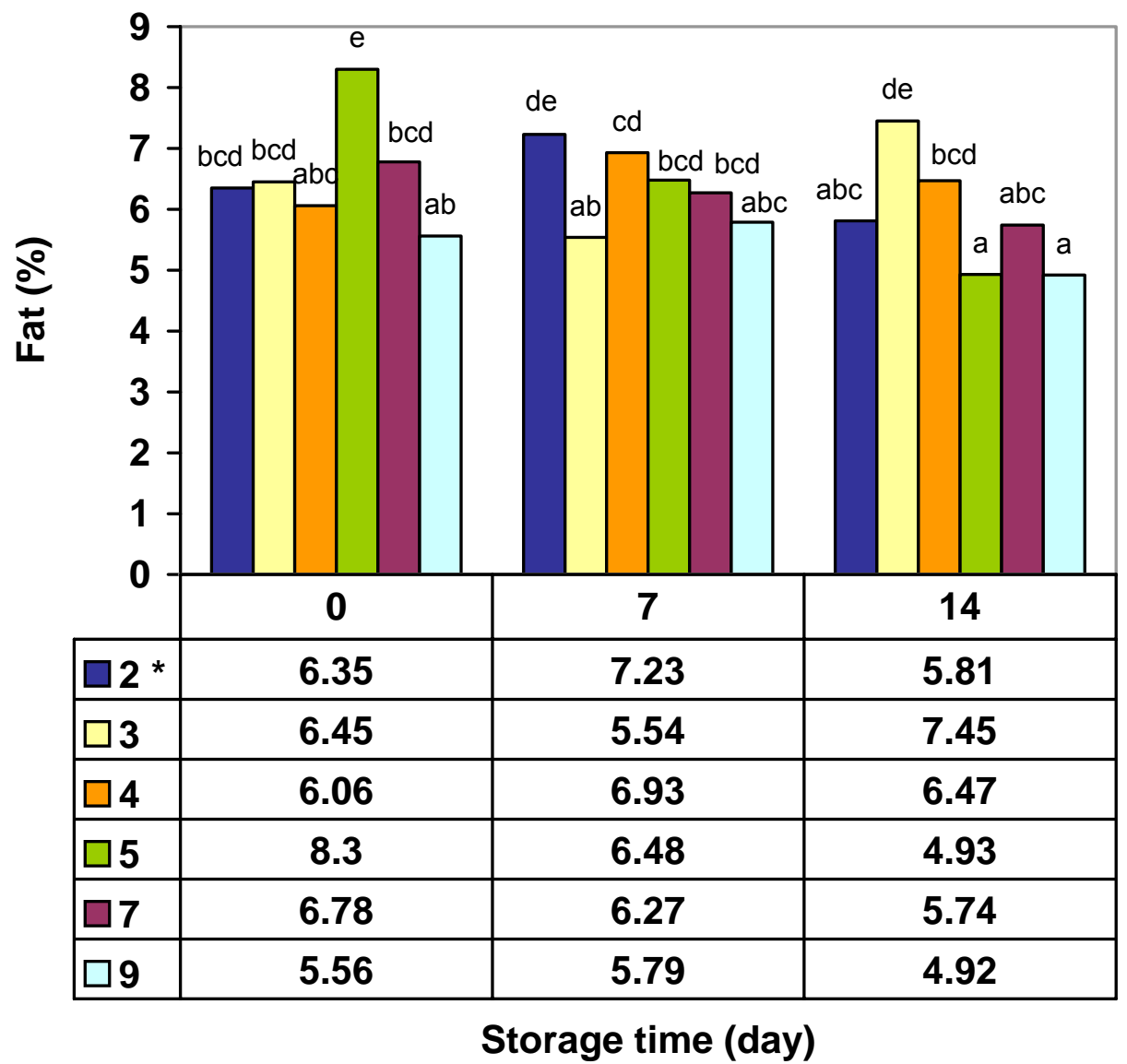

Figure 6. Effect of duration of feeding and storage time on fat content.

${ }^{\text {abcde }}$ Bars with different superscripts are different $(p<0.05)$.

${ }^{*}$ Fish were sampled at 2, 3, 4, 5, 7, and 9 weeks of feeding. 


\section{APPENDICES}




\section{Appendix 1}

Vitamin E concentrations of feed

\begin{tabular}{|c|c|c|}
\hline \multirow{2}{*}{$\begin{array}{c}\text { Duration of } \\
\text { feeding, wk }\end{array}$} & \multicolumn{2}{|c|}{ Vitamin E concentration, mg/kg } \\
\cline { 2 - 3 } & $\mathrm{C}^{*}$ & VE $^{* *}$ \\
\hline 0 & 191.1 & 4926.1 \\
2 & 194.5 & 4746.1 \\
3 & 195.7 & 4464.1 \\
4 & 177.8 & 4561.0 \\
5 & 147.5 & 5472.7 \\
7 & 106.6 & 2602.6 \\
8 & 91.8 & 3138.5 \\
9 & 117.5 & 3281.2 \\
\hline
\end{tabular}

${ }^{*}$ C- control diet, ${ }^{* *}$ VE- 5000 mg/kg diet. 


\section{Appendix 2}

\section{Statistical program}

option LS=80 pagesize $=\mathbf{6 0}$ nonumber;

title ;

data; input week rep day diet \$ response;

cards;

proc print;

proc glm; classes diet rep week day;

model response=diet $\operatorname{diet}(\mathrm{rep})$ week week$^{*}$ diet week$^{*} \operatorname{diet}(\mathrm{rep})$ day day $^{*}{ } \operatorname{diet}$ day $^{*}$ week day* week ${ }^{*}$ diet;

test $\mathrm{H}=\operatorname{diet} \mathrm{E}=\operatorname{diet}(\mathrm{rep})$;

test $\mathrm{H}=$ week week $^{*} \operatorname{diet} \mathrm{E}=$ week $^{*} \operatorname{diet}(\mathrm{rep})$;

Ismeans diet/pdiff $E=\operatorname{diet}(r e p)$;

Ismeans week week ${ }^{*}$ diet/pdiff $E=$ week $^{*}$ diet;

Ismeans day day ${ }^{*}$ diet day $^{*}$ week day $^{*}{ }^{*}$ week$^{*}$ diet/pdiff;

run; 


\section{Appendix 3}

\section{Statistical program for weight gain}

option LS=80 pagesize $=60$ nonumber;

title

data wholewt; input week rep diet \$ wholewt;

cards;

proc print;

proc glm; classes diet rep week ;

model wholewt=diet $\operatorname{diet}(\mathrm{rep})$ week week ${ }^{*}$ diet;

test $\mathrm{H}=\operatorname{diet} \mathrm{E}=\operatorname{diet}(\mathrm{rep})$;

Ismeans diet/pdiff $E=\operatorname{diet}(r e p)$;

Ismeans week week*diet/pdiff ;

run; 


\section{Appendix 4}

Statistical program for moisture, fat, vitamin E content of fasted fish at week 9.

option LS=80 pagesize $=\mathbf{6 0}$ nonumber;

title ;

data response; input diet $\$$ rep fasted $\$$ day $\$$ response;

cards;

proc print;

proc glm; classes diet rep fasted day;

model response $=$ diet $\operatorname{diet}(\mathrm{rep})$ fasted fasted ${ }^{*}$ diet fasted ${ }^{*}$ diet (rep)day day $^{*}$ diet diet $^{\star}$ fasted ${ }^{\star}$ day;

test $\mathrm{H}=\operatorname{diet} \mathrm{E}=\operatorname{diet}(\mathrm{rep})$;

test $\mathrm{H}=$ fasted fasted ${ }^{*}$ diet $\mathrm{E}=$ fasted ${ }^{*}$ diet (rep);

Ismeans diet/pdiff $E=\operatorname{diet}(r e p) ;$

Ismeans fasted fasted ${ }^{*}$ diet/pdiff $E=$ fasted $^{*}$ diet (rep);

Ismeans day day $^{*}{ }_{\text {diet }} \operatorname{diet}^{\star}$ fasted $^{*}$ day/pdiff;

run; 


\section{Appendix 5}

\section{Statistical program for psychrotrophic counts of fasted fish at week 9}

option LS=80 pagesize $=\mathbf{6 0}$ nonumber;

title ;

data response; input diet $\$$ rep fasted $\$$ day $\$$ response;

cards;

proc print;

proc glm; classes diet rep fasted day;

model response $=$ diet $\operatorname{diet}(\mathrm{rep})$ fasted fasted ${ }^{*}$ diet fasted ${ }^{*}$ diet (rep)day day $^{*}$ diet diet $^{\star}$ fasted ${ }^{\star}$ day;

test $\mathrm{H}=\operatorname{diet} \mathrm{E}=\operatorname{diet}(\mathrm{rep})$;

test $\mathrm{H}=$ fasted fasted ${ }^{*}$ diet $\mathrm{E}=$ fasted $^{*}$ diet (rep);

Ismeans diet/pdiff $E=\operatorname{diet}(r e p)$;

Ismeans fasted fasted ${ }^{*}$ diet/pdiff $E=$ fasted $^{*}$ diet (rep);

Ismeans day day*diet $\operatorname{diet}^{\star} f a s t e d^{*}$ day/pdiff;

run; 


\section{Appendix 6}

Statistical program for TBARS of fasted fish at week 9

option LS=80 pagesize $=\mathbf{6 0}$ nonumber;

title ;

data tbars; input diet \$ rep fasted \$ response;

cards;

proc print;

proc glm; classes diet rep fasted;

model response $=$ diet diet(rep) fasted diet ${ }^{\star}$ fasted;

test $\mathrm{H}=\operatorname{diet} \mathrm{E}=\operatorname{diet}(\mathrm{rep})$;

Ismeans diet/pdiff $E=\operatorname{diet}(r e p)$;

Ismeans fasted $\operatorname{diet}^{\star} f a s t e d / p d i f f ;$

run; 
CHAPTER 3

EFFICACY OF ACIDIFIED SODIUM CHLORITE IN EXTENDING STORAGE STABILITY OF

RAINBOW TROUT (Oncorhynchus mykiss) FILLETS 


\begin{abstract}
Fresh rainbow trout were obtained from a local farm, mechanically stunned, packed in ice, and transported to West Virginia University within $3 \mathrm{~h}$ of harvest. Gutting and filleting were performed manually, and fillets were subsequently washed in a dilute salt/ ice slurry and rinsed under running tap water to remove blood and waste. These fillets were drained overnight at $4^{\circ} \mathrm{C}$ to remove excess water. The ASC solution was prepared by mixing equal volumes of Sanova Activator ${ }^{\circledR}$ and Sanova ${ }^{\circledR}$ base. The activator and base were mixed immediately prior to treatment application. At room temperature, fillets were dipped in water for $10 \mathrm{~s}$ and then drained for $10 \mathrm{~s}$ before treatment with ASC. Pre-dipped fillets were placed in an agitating ASC solution for $30 \mathrm{~s}$ and allowed to drain for $10 \mathrm{~s}$. The ratio of fish-tosolution was1:3 (W/V). Subsequently, fresh fillets were aerobically packed on styrofoam trays and wrapped with polyvinyl chloride (PVC) film. Fillets were stored at $1-2^{\circ} \mathrm{C}$ for 0,8 , and 15 days. Four intervention treatments, control (no treatment), water, 50 ppm ASC, and 1000 ppm ASC and three storage periods resulted in 12 treatment combinations. A randomized complete block design with a split-plot arrangement of treatments was replicated on three separate days. Significance was established at $p<0.05$. A significant interaction $(p<0.05)$ of treatment and storage time was observed for psychrotrophic counts. Aerobic plate counts were not affected $(p>0.05)$ by intervention; however, a significant increase in aerobic plate counts was observed during storage $(\mathrm{p}<0.05)$. Fillet $\mathrm{pH}$, moisture, fat, TBARS, fatty acid composition, TVBN, TMA, color, cook yield, and shear force were not affected $(p>0.05)$ by antimicrobial intervention. TBARS decreased $(p<0.05)$ during storage.
\end{abstract}


Generally, percent fatty acids were stable during storage ( $p>0.05)$; however, C15 and $\mathrm{C} 20: 2$ decreased $(p<0.05)$. Fat content, TMA, $L^{*}, b^{*}$, and cook yield increased $(p<0.05)$ during storage. Fillet $\mathrm{pH}$, moisture, TVBN, $a^{*}$ value, and shear force did not change $(p>0.05)$ with increasing storage.

Key words: acidified sodium chlorite, rainbow trout, microbial counts, lipid oxidation, fatty acids 


\section{INTRODUCTION}

Fish are highly perishable, and post-mortem autolytic and microbiological changes reduce the storage stability of these products. This perishability necessitates development of interventions to extend shelf life and preserve product quality. Application of antimicrobials is one way of reducing microbial spoilage in fish. Chemicals such as sodium hypochlorite, broad spectrum antibiotics, ethylenediaminetetraacetic acid, glucose oxidase, organic acids (Haard 1992), and chlorine dioxide (Kim and others 1999) have been used to delay microbial spoilage in fish.

Acidified sodium chlorite (ASC) is an antimicrobial agent approved by the U.S. Food and Drug Administration as a secondary direct food additive permitted in food for human consumption. ASC is approved at 500 to1,200 ppm for use on poultry, red meat, comminuted meat products and processed fruits and vegetables to reduce bacterial contamination; whereas, in seafood, ASC is approved at a concentration of 40 to $50 \mathrm{ppm}$. ASC can be used to rinse, wash, thaw, transport, or store seafood. ASC is an antibacterial agent prepared by mixing sodium chlorite with a generally recognized - as - safe acid (Anonymous 1999). The antimicrobial acitivity of acidified sodium chlorite is attributed to the oxidative effect of chlorous acid, generated from the conversion of chlorite ion into its acid form under acidic conditions. Chlorous acid is a metastable oxychlorine species that decomposes to form chlorate ion, chlorine dioxide, and chloride ion (Gordon and others 1972). Bacterial contamination on beef and poultry was reduced by treating the carcass with 1200 ppm of acidified sodium chlorite (Castillo and others 1999; Kemp and 
others 2001). Su and Morrissey (2003) reported that treatment of salmon fillets with 50 ppm ASC reduced the total plate counts (viable cell counts) of fillets. The objective of this research is to study the efficacy of ASC, at approved and higher concentrations, in extending the storage stability and quality of rainbow trout fillets.

\section{MATERIALS AND METHODS}

\section{Processing of fish}

Fresh rainbow trout were obtained from a local farm, mechanically stunned, packed in ice and transported to West Virginia University within $3 \mathrm{~h}$ of harvest. Gutting and filleting were performed manually, and fillets were subsequently washed in a dilute salt/ ice slurry and rinsed under running tap water to remove blood and waste. Following processing, fillets were drained overnight at $4^{\circ} \mathrm{C}$ to remove excess water.

\section{Preparation of ASC solution}

The ASC solution was prepared by mixing equal volumes of Sanova Activator ${ }^{\circledR}$ and Sanova ${ }^{\circledR}$ base (Alcide Corporation, Redmond, WA, U.S.A). The activator and base were obtained in separate containers and stored at room temperature. A final concentration of $50 \mathrm{ppm}$ ASC was obtained by mixing $0.66 \%$ citric acid (Sanova Activator $^{\circledR}$ ) and $0.01 \%$ sodium chlorite (Sanova ${ }^{\circledR}$ base). For 1000 ppm, $0.76 \%$ citric acid (Sanova Activator ${ }^{\circledR}$ ) and $0.2 \%$ sodium chlorite (Sanova ${ }^{\circledR}$ base) were used. The activator and base were mixed immediately before application of treatments. The sodium chlorite concentration of the ASC solution was determined by titration with sodium thiosulphate before and after dipping the fillets. 


\section{Treatment of fillets}

Four intervention treatments, control, water, 50 ppm ASC, and 1000 ppm ASC and three display days resulted in 12 treatment combinations. Fifteen fillets were randomly assigned to each treatment. At room temperature, fillets were dipped in water for $10 \mathrm{~s}$ and then drained for $10 \mathrm{~s}$ on oven trays before treatment with ASC. Pre-dipping of fillets in water was done immediately before applying the treatments, to ensure uniform surface tension moisture. For each batch of 15 fillets, ASC solution was freshly prepared and the ratio of fish-to-solution was 1:3 (W/V). Predipped fillets were dipped in agitating ASC solution for $30 \mathrm{~s}$ and allowed to drain on

oven trays for $10 \mathrm{~s}$. Agitation was accomplished by placing the tub containing the ASC solution on a shaker table. For the water treatment, pre-dipped fillets were dipped in agitating tap water $(1: 3(\mathrm{~W} / \mathrm{V}))$ and allowed to drain on oven trays for $10 \mathrm{~s}$. Fillets that did not receive any treatment were used as the control. Following treatment, fillets were aerobically packed on styrofoam trays and wrapped with polyvinyl chloride (PVC) film. Fillets were stored at $1-2^{\circ} \mathrm{C}$ for 0,8 , and 15 days. Five fillets from each treatment were sampled at each display period to conduct analyses.

\section{Chemical and physical analyses}

Moisture and Fat: Moisture and fat were determined according to standard AOAC procedures (1990).

$\mathrm{pH}$ : The $\mathrm{pH}$ of $\mathrm{ASC}$ solutions and muscle were measured using a $\mathrm{pH} /$ ion analyzer 350 (Corning Inc.; Corning, NY) equipped with a general surface combination probe. The $\mathrm{pH}$ of ASC solutions was measured before and after dipping the fillets. On each display day, muscle $\mathrm{pH}$ was randomly recorded on one of the five fillets assigned to 
that display period. One reading was taken at the cranial and caudal halves of the fillet. These two values were averaged and recorded as fillet $\mathrm{pH}$.

Microbial analysis: Surface counts of psychrotrophic (PPC) and aerobic bacteria (APC) were determined on all five fillets of each treatment. A $11.4 \mathrm{~cm}^{2}$ core was taken from the center of the cranial portion of the fillet using a sharp-edged metal corer. The cored sample was blended with $25 \mathrm{~mL}$ of $0.1 \%$ peptone water in a Stomacher 400 blender (Tekmer, Cincinnati, Ohio, U.S.A) for $30 \mathrm{~s}$. A $1 \mathrm{~mL}$ aliquot of the homogenate was serially diluted with peptone water and each diluent was spread plated on duplicate plates of plate count agar (Swanson and others 1992). At day 0 , a $0.1 \mathrm{~mL}$ aliquot was directly spread on the plates. The initial ratio of sample to diluent was $0.912 \mathrm{~cm}^{2} / \mathrm{mL}$. Inverted plates were incubated for $24 \mathrm{~h}$ at $25^{\circ} \mathrm{C}$ and $37^{\circ} \mathrm{C}$ for psychrotrophic and aerobic bacteria, respectively. Counts were reported as $\log _{10} \mathrm{CFU} / \mathrm{cm}^{2}$. These counts represent microflora present on the flesh and skin sides of the fillet because the core passed through the fillet.

Total volatile base nitrogen (TVBN) and Trimethyl amines (TMA):

TVBN and TMA content was measured by a steam distillation method (Malle and Tao 1987).

Thiobarbituric acid Reactive Substances (TBARS): One fillet from each treatment was skinned (excluding belly flap), cut into small pieces, frozen in liquid $\mathrm{N}_{2}$, and powdered in a commercial blender (Waring, New Hartford, Conn., U.S.A). TBARS in the powdered samples were measured calorimetrically using 2-thiobarbituric acid (Yu and Sinnhuber 1957). Absorbance was read at $535 \mathrm{~nm}$ using a Spectronic 20D 
spectrophotometer (Milton Roy, NJ, U.S.A). Results were expressed as mg malonaldehyde (MDA) per $\mathrm{kg}$ of sample.

Fatty acid analysis: Total lipids were extracted according to the rapid method of total lipid extraction and purification of Bligh and Dyer (1959). Fatty acid methyl esters (FAME) were prepared according to Fritshe and Johnston (1990) (Appendix 1). A Varian 3800 gas chromatograph (Varian Inc; Palo Alto, CA, U.S.A) equipped with a Varian 4800 analyzer (Varian Inc., Palo Alto, CA, U.S.A) and a flame ionizing detector was used to separate and identify the fatty acids; a split ratio of $10: 1$ was used. The column was a W Cot fused silica capillary (FAME) column, $50 \mathrm{~mm}$ long and $5 \mu \mathrm{m}$ i.d (Varian Inc, Palo Alto, CA, U.S.A) and nitrogen as carrier gas was employed. Temperatures of injector and detector were $275^{\circ} \mathrm{C}$ and $300^{\circ} \mathrm{C}$, respectively. Initial oven temperature was $140^{\circ} \mathrm{C}$ held for $5 \mathrm{~min}$, then increased to $200^{\circ} \mathrm{C}$ at the rate of $4^{\circ} \mathrm{C} / \mathrm{min}$ and held for $6 \mathrm{~min}$. Final oven temperature was increased to $220^{\circ} \mathrm{C}$ at the rate of $3^{\circ} \mathrm{C} / \mathrm{min}$ and held for $15 \mathrm{~min}$. Total run time was 48 min. Fatty acid methyl esters were identified by comparing retention times with those of FAME 37 standard (Sigma-Aldrich, St.Louis, MO, U.S.A). Individual fatty acid values were expressed as a percent of total fatty acids measured. Samples were injected once for analysis.

Color: Fillet color was measured with a Minolta chromameter (Model CR-300, Minolta camera Co Ltd.; Osaka, Japan). The instrument was calibrated using a standard white plate No.21333180 (CIE $L^{*}$ 93.1; $\left.a^{*} 0.3135 ; b^{*} 0.3198\right) . \quad L^{*}$ (lightness), $a^{*}$ (redness), and $b^{*}$ (yellowness) values were recorded at one randomly 
chosen location on the cranial and caudal portions of fillet. The mean of these two values was used as the observation for that fillet.

Shear force and cook yield: Shear force was measured using a Texture Analyzer (Model TA-Hdi ; Texture Technologies Corp., Scarsdale, N.Y., U.S.A) with a 5-blade Kramer shear attachment at a cross speed of $127 \mathrm{~mm} / \mathrm{min}$. A $3 \times 8 \mathrm{~cm}$ strip of the cooked fillet was removed, skinned, weighed and placed beneath the blades with the skin side up. Values were expressed as $\mathrm{g}$ force/g of sample. Cook yield was calculated by expressing cooked fillet weight as a percent of raw fillet weight.

ASC solution concentrations: Sodium chlorite content of the treatment solutions was determined before and after dipping the fillets in ASC as described in Appendix 2.

\section{Experimental design}

Four intervention treatments, control, water, 50 ppm ASC, and 1000 ppm ASC, and three display days resulted in 12 treatment combinations. A randomized complete block design with a split-plot arrangement of treatments was replicated on

three separate days (Appendix 3). The General Linear Model (GLM) procedure of SAS (SAS Institute, Inc., 1999) was used to establish main and interaction effects. The PDIFF of the Ismeans procedure was used to separate means. Significance was established at $p<0.05$.

\section{RESULTS AND DISCUSSION}

The $\mathrm{pH}$ of 50 and $1000 \mathrm{ppm}$ solutions increased from 2.53 and 2.67 to 2.68 and 2.75, respectively, after dipping the fillets in ASC for $30 \mathrm{~s}$. Sodium chlorite concentrations of soutions were in the range of 52-56 and 997-1011 ppm. Following 
dipping, concentrations were 49-51 and 989-997 ppm. The pH of fillets treated with ASC was not different $(\mathrm{p}>0.05)$ from the $\mathrm{pH}$ of the control fillet, and increasing storage time did not affect $(p>0.05)$ fillet $\mathrm{pH}$ (Table $1 \& 3)$. Fillet moisture and fat content was not affected ( $p>0.05)$ by treatment (Table 1). Kim and others (1998) showed that treatment of salmon and red grouper fillets with chlorine dioxide did not significantly affect the moisture, fat and protein of fillets when compared to the nontreated control. Fat content increased $(p<0.05)$ during storage, but the moisture content of the fillets remained unchanged $(p>0.05)$ (Table 3$)$.

\section{Microbial counts}

A significant $(p<0.05)$ treatment by day interaction was observed for psychrotrophic counts (Figure 1). Initial counts (day 0) were significantly lower $(p<0.05)$ for fillets treated with 50 ppm of ASC compared to all other treatments; no differences $(p>0.05)$ were observed between water and 1000 ppm treatments. Psychrotrophic counts increased $(p<0.05)$ during storage. Fillets dipped in 1000 ppm ASC had significantly lower $(p<0.05)$ counts than all other treatments at 8 and $15 \mathrm{~d}$. Aerobic plate counts were not $(p>0.05)$ affected by treatment (Table 2$)$, but they increased from $1.94 \log _{10}$ to $5.02 \log _{10} \mathrm{CFU} / \mathrm{cm}^{2}(p<0.05)$ as time at $1-2^{\circ} \mathrm{C}$ increased (Table 4). Similar results were observed by Su and Morrissey (2003) for salmon fillets dipped in $50 \mathrm{ppm}$ of ASC for $1 \mathrm{~min}$ and stored on ice or at $5^{\circ} \mathrm{C}$ for 7 days. In their study, ASC treatment reduced initial total plate counts by $0.3 \log$ units, however a gradual increase in counts was observed for all samples during storage. They demonstrated that the bactericidal activity of ASC is primarily due to the generation of chlorine dioxide and chlorous acid and not related to low $\mathrm{pH}$ of the 
ASC solution. By suspending the Listeria monocytogenes cocktail (6.91 log $\mathrm{CFU} / \mathrm{mL}$ ) in 9 volumes of Butterfield's phosphate buffer that had been adjusted to $\mathrm{pH}$ 3.03 and 3.30 with $1 \mathrm{~N}$ hydrochloric acid they demonstrated this mechanism of ASC action. The survival of the cells was determined immediately after mixing (15 s) and after $1,2,3$, and 5 min by the total plate count method. Listeria monocytogenes survived well in acidic phosphate solutions and decreased only slightly after $5 \mathrm{~min}$, from 5.91 to 5.87 and $5.82 \log \mathrm{CFU} / \mathrm{mL}$ at pHs 3.30 and 3.03, respectively. These authors believed that the low bactericidal activity of ASC was due to its interaction with fish muscle protein, resulting in less interaction between ASC and bacterial cell walls. On the other hand, Warf and Kemp (2001) reported that the antimicrobial activity of ASC is due to the uncharged chlorous acid; it penetrates bacterial cell walls and disrupts protein synthesis. In our study low initial counts on the fillets and short contact time (30 s) between fillets and ASC solution may have contributed to our observation that ASC has limited antimicrobial action.

\section{Total volatile base nitrogen (TVBN) and Trimethylamines (TMA) content}

TVBN and TMA were not affected $(p>0.05)$ by treatment intervention $(p>0.05)$ (Table 2). TMA values increased during storage $(p<0.05)$ (Table 4). A trend of increasing TVBN values was observed; however this response was not affected by storage $(p>0.05)$ (Table 4). TVBN is widely used to indicate fish quality and spoilage (Pivarnik and others 1998; Duflos and others 1999). Initial TVBN values were higher than the values reported for rainbow trout. TVBN values of rainbow trout fillets stored at $1 \pm 1^{\circ} \mathrm{C}$ for 4 days exceeded $25 \mathrm{mg} \mathrm{N} / 100 \mathrm{~g}$ of muscle (Giminez and others 2002) which is comparable to the values observed in the present study. Mazorra- 
Manzano and others (2000) reported an insignificant change in TVBN values with storage time for black skipjack stored at 1 to $3^{\circ} \mathrm{C}$ for $24 \mathrm{~d}$; these values ranged between 25.5 to $34.3 \mathrm{mg} \mathrm{N} / 100 \mathrm{~g}$ muscle during storage. TVBN is more useful in assessing degree of freshness than in evaluating changes during the first stages of spoilage (El Marrack-chi and others 1990).

An increase in TMA with storage time was reported for rainbow trout fillets stored at $4^{\circ} \mathrm{C}$ (Rodriguez and others 1999). However, TMA values observed in our study were higher than these reported values. Production of TMA is dependent on species, sex, age, time of year and muscle type (Hughes 1959; Shirai and others 1988). Freshwater fish do not contain trimethylamine oxide (TMAO) which produces TMA by bacterial action. In our study, high levels of TMA in fillets might have accumulated from the diet which is formulated with aquatic protein and fat sources. Marine fish typically contain $1-100 \mathrm{mg}$ of TMAO per $100 \mathrm{~g}$ of muscle (Stansby and Olcott 1963). Rodriguez and others (1999) suggested that TMA value is affected by bacterial flora, feed characteristics and method of storage, and it may not be useful for evaluating freshness of rainbow trout.

\section{Lipid oxidation and fatty acid composition}

ASC formed by acidification of chlorous acid decompose into chlorine dioxide, chlorate ion and chlorite ion (Gordon and others 1972). Treatment of fillets with ASC did not affect $(p>0.05)$ TBARS or measurable fatty acid content of the fillets (Table 1 \& 5). Kim and others (1997) reported that TBARS were higher for salmon and red grouper fillets dipped in 100 and 200 ppm chlorine dioxide for 5 min compared to the control (untreated) and $40 \mathrm{ppm}$ fillets. However, $100 \mathrm{ppm}$ and $200 \mathrm{ppm}$ treatments 
were not different from each other. In addition these authors also reported that fatty acid composition of fillets was not affected by chlorine dioxide treatment. Comparing our results with the aforementioned study, no effect $(p>0.05)$ of ASC on fillet TBARS may be associated with differences in contact time. In addition to different exposure times (5 min VS $30 \mathrm{~s}$ ), evaporation of treatment solution on the fillet surface, and interaction of ASC or its decomposed components with other organic compounds in the fillet may have caused minimal interaction of chlorine dioxide with lipids reducing the likelihood of ASC-induced lipid deterioration. A decrease $(p<0.05)$ in TBARS value was observed on day 8 , and this value was constant through 15 days of storage. The decrease in TBARS may be due to result of malondialdehyde reacting with fish proteins (Known and others 1965); this interaction decreases availability of malonaldehyde for calorimetric determination. Percent fatty acid content of fillets did not change ( $p>0.05)$ during storage, except for $\mathrm{C} 15$ (Pentadeconoic acid) and C20:2 (Cis $-11,14$ - eicosadienoic acid) which were slightly lower $(p<0.05)$ on day 8 and day 15 (Table 6$)$. The ratio of $\omega 3$ to $\omega 6$ was 0.8 and did not change $(p>0.05)$ with treatment intervention or storage time (Table $5 \& 6$ ).

\section{Color}

Treatment with ASC did not cause $(p>0.05)$ color changes (Table 1$). L^{*}$ and $b^{*}$ values increased $(p<0.05)$ during storage $($ Table 3$)$; whereas, $a^{*}$ value remain unchanged $(p>0.05)$ (Table 3). Eventhough $1000 \mathrm{ppm}$ treated fillets appeared paler than the control fillets, the differences were not significant $(p>0.05)$. Similar results were reported by Su and Morrissey (2003) in that dipping salmon fillets and whole salmon in 50 ppm ASC for 1 min did not result in visible color loss. Similar increases 
in $L^{*}$ value during storage were observed in our earlier study (chapter 1 ). However these changes are not clearly understood and need to be studied further, because there is limited literature available in this area of fish fillet color variable.

Nonetheless, Robb and others (2000) observed increased lightness of rainbow trout fillets with lower post mortem $\mathrm{pH}$. In addition, hue and chroma increased during the first four days of slaughter.

\section{Cook yield and shear force}

Cook yield and shear force were not affected $(P>0.05)$ by intervention treatments (Table 1). Cook yield increased during storage $(p<0.05)$ and shear force was not affected $(p>0.05)($ Table 3$)$. Eventhough, treatments did not cause a significant change in cook yield, dipping of fillets in ASC followed by immediate cooking may have caused some denaturation of proteins on the surface, resulting in more water loss during cooking thereby decreasing the cook yield. However the $\mathrm{pH}$ equilibrium between surface and deeper portions of the muscle after $8 \mathrm{~d}$ and $15 \mathrm{~d}$ may have caused the proteins to regain their native form and thereby improve the water holding capacity of the muscle and thereby increase cook yield. 


\section{CONCLUSIONS}

Treatment of fillets with 50 and 1000 ppm ASC reduced psychrotrophic counts of fillets, but had no affect on aerobic plate counts. Dose dependent responses were not observed for lipid oxidation or fatty acid composition. ASC did not affect fillet color when compared to water and control treatments. Based on these results, 50

ppm ASC performed equally as well as 1000 ppm ASC. Hence, it may not be practical to apply high concentrations of ASC to rainbow trout fillets when a similar affect could be obtained at the approved concentrations (50 ppm). 


\section{REFERENCES}

Anonymous. 1999. 21 CFR 173.325. Acidified sodium chlorite solutions. Code of Federal Regulations, Office of the Federal Register, U.S. Government Printing Office, Washington, DC.

AOAC. 1990. Official Methods of Analysis. 15th ed. Washington, DC: Association of Official Analytical Chemists.

Bligh EG, and Dyer WJ. 1959. A rapid method of total lipid extraction and purification Can J Biochem Physiol. 37:911-917.

Castillo A, Lucia LM, Kemp GK, and Acuff GR. 1999. Reduction of Escherichia coli O157:H7 and Salmonella typhimurium on beef carcass surfaces using acidified sodium chlorite. J. Food Prot. 62(6):580-584.

Duflos G, Dervin C, Malle P, and Bouquelet S. 1999. Use of biogenic amines to evaluate spoilage in plaice (Pleuronectes platessa) and whiting (Merlangus merlangus). J AOAC Int 82(6):1357-1363.

El Marrakchi A, Bennour M, Bouchriti N, Hamama A, and Tagafait H. 1990. Sensory, chemical, and microbiological assessments of Moroccan sardines (Sardina pilchardus) stored in ice. J Food Prot 53(7):600-605.

Fritshe KL, and Johnston PU. 1990. Effect of dietary-linolenic acid on growth, metastasis, fatty acid profile and prostaglandin production of two murine mammory adeno carcinomas. J Nutr.120:1601-1609.

Gimenez B, Roncales P, and Beltran JA. 2002. Modified atmosphere packaging of filleted rainbow trout. J. Sci Food and Agric. 82: 1154-1159.

Gordon G, Kieffer RB, and Rosenblatt DH. 1972. The chemistry of chlorine dioxide. In: Lepard SJ, editor. Progress in inorganic chemistry. Vol 15. New York: Wileyinterscience publishers. p 201-286.

Haard NF. 1992. Technological aspects of extending prime quality of seafood: A review. Journal of Aquatic Food Product Technology 1(3/4): 9-27.

Hughes RB. 1959. Chemical studies on the herring (Clupea harengus) I. Trimethlyamine oxide and volatile amines in fresh, spoiling and cooked herring flesh. J Sci Food Agric 10:431-436.

Kemp GK, Aldrich ML, Guerra ML, and Schneider KR. 2001. Continuous online processing of fecal-and ingesta-contaminated poultry carcasses using acidified sodium chlorite antimicrobial intervention. J Food Prot. 64(6):807-812. 
Kim JM, Lee YS, O'Keefe SF, and Wei Cl. 1997. Effect of chlorine dioxide treatment on lipid oxidation and fatty acid composition in salmon and red grouper

fillets. J. Am. Oil. Chem. Soc. 74: 539-542.

Kim JM, Du WX, Otwell WS, Marshall MR, and Wei Cl. 1998. Nutrients in salmon and red grouper fillets as affected by chlorine dioxide $\left(\mathrm{ClO}_{2}\right)$ treatment.

J. Food Sci. 63(4): 629-633.

Kim JM, Huang TS, Marshall MR, and Wei.Cl. 1999. Chlorine dioxide treatment of sea foods to reduce bacterial loads. J. Food Sci. 64(6): 1089-1093.

Known TW, Menzel DB, and Olcott HS. 1965. Reactivity of malonaldehyde with food constituents. J. Food Sci. 30:808-813.

Malle $\mathrm{P}$, and Tao SH. 1987. Rapid quantitative determination of trimethylamine using steam distillation. J Food Prot. 50(9):756-760.

Mazzora-Manzano MA, Pacheco-Aguilar R, Díaz-Rojas El, and Lugo-Sanchez ME. 2000. Postmortem changes in black skipjack muscle during storage in ice. J Food Sci. 65(5):774-779.

Pivarnik LF, Thiam M, and Ellis PC. 1998. Rapid determination of volatile bases in fish by using an ammonia ion-selective electrode. J AOAC Int 81(5):1011-1022.

Robb DHF, Kestin SC, and Warris PD. 2000. Muscle activity at slaughter: I. Changes in flesh color and gaping in rainbow trout. Aquaculture. 182:261-269.

Rodriguez CJ, Besteiro I, and Pascual C. 1999. Biochemical changes in fresh water rainbow trout (Oncorhynchus mykiss) during chilled storage. J. Sci Food and Agric. 79:1473-1480.

SAS Institute Inc. 1999. SAS users guide: Basics version 8. Statistical Analysis System Institute Inc. Cary, NC.

Shirai T, Fuke S, Yamaguchi K and Konosu S. 1988. Nucleotides, quaternary ammonium bases and related compounds in the raw and heated muscle of salmon. Nip Sui Gak 54:1199-1207.

Stansby ME, and Olcott HS. 1963. Chapter 26. Composition of fish. In: Indusrial fishery technology. New York: Reinhold Pub.

Su YC, and Morrissey MT. 2003. Reducing levels of Listeria monocytogenes contamination on raw salmon with acidified sodium chlorite. J. Food Prot. 66(5): 812818. 
Swanson KMJ, Busta FF, Peterson EH, and Johnson MG. 1992. Colony count methods. In:Vanderzant C, Splittstoesser DN, editors. Compendium of Methods for the Microbiological Examination of Foods. 3rd edition. Washington DC: American Public Health Association. p 75-95.

Warf CC Jr, and Kemp GK. 2001. Chemistry and mode of action of acidified sodium chlorite [abstract]. In: IFT Annual Meeting Abstracts; 2001; New Orleans, La. Chicago III.: Institute of Food Technologists. Abstract nr 91-1.

Yu TC, and Sinnhuber RO. 1957. 2-thiobarbituric acid method for the measurement of rancidity in fishery products. Food Technol. 11(2):104-108. 
Table 1. Effect of ASC treatment on muscle pH, moisture, fat, TBARS, color, cook yield and shear force of fillets.

\begin{tabular}{|l|c|c|c|c|}
\hline \multirow{2}{*}{ Trait } & \multicolumn{3}{|c|}{ Treatment } \\
\cline { 2 - 5 } & Control & Water & $\begin{array}{c}50 \mathrm{ppm} \\
\text { ASC }\end{array}$ & $\begin{array}{c}1000 \mathrm{ppm} \\
\text { ASC }\end{array}$ \\
\hline Muscle pH & $6.11^{\mathrm{a}}$ & $6.39^{\mathrm{a}}$ & $6.29^{\mathrm{a}}$ & $6.31^{\mathrm{a}}$ \\
Moisture, \% & $75.64^{\mathrm{a}}$ & $75.32^{\mathrm{a}}$ & $75.54^{\mathrm{a}}$ & $76.13^{\mathrm{a}}$ \\
Fat, \% & $5.22^{\mathrm{a}}$ & $5.44^{\mathrm{a}}$ & $5.43^{\mathrm{a}}$ & $5.15^{\mathrm{a}}$ \\
TBARS, mg MDA/100g & $0.6^{\mathrm{a}}$ & $0.8^{\mathrm{a}}$ & $0.8^{\mathrm{a}}$ & $0.9^{\mathrm{a}}$ \\
L*$^{*}$ value & $48.76^{\mathrm{a}}$ & $49.17^{\mathrm{a}}$ & $50.53^{\mathrm{a}}$ & $50.80^{\mathrm{a}}$ \\
a $^{*}$ value & $-1.62^{\mathrm{a}}$ & $-2.01^{\mathrm{a}}$ & $-2.31^{\mathrm{a}}$ & $-2.37^{\mathrm{a}}$ \\
b $^{*}$ value & $8.47^{\mathrm{a}}$ & $7.57^{\mathrm{a}}$ & $7.65^{\mathrm{a}}$ & $6.16^{\mathrm{a}}$ \\
Cook yield, \% & $78.59^{\mathrm{a}}$ & $77.89^{\mathrm{a}}$ & $77.45^{\mathrm{a}}$ & $77.47^{\mathrm{a}}$ \\
Shear force, g/g of sample & $266.43^{\mathrm{a}}$ & $263.75^{\mathrm{a}}$ & $249.55^{\mathrm{a}}$ & $290.33^{\mathrm{a}}$ \\
\hline
\end{tabular}

${ }^{\mathrm{a}}$ Means within a row with different superscripts are different $(p<0.05)$. 
Table 2. Effect of ASC treatment on APC, TVBN, and TMA of fillets.

\begin{tabular}{|l|c|c|c|c|}
\hline \multirow{2}{*}{ Trait } & \multicolumn{4}{|c|}{ Treatment } \\
\cline { 2 - 5 } & Control & Water & $\begin{array}{c}50 \mathrm{ppm} \\
\text { ASC }\end{array}$ & $\begin{array}{c}1000 \mathrm{ppm} \\
\text { ASC }\end{array}$ \\
\hline APC, $\log _{10}$ CFU/cm ${ }^{2}$ & $4.08^{\mathrm{a}}$ & $3.76^{\mathrm{a}}$ & $3.54^{\mathrm{a}}$ & $3.43^{\mathrm{a}}$ \\
TVBN, mg N/100g muscle & $24.88^{\mathrm{a}}$ & $26.98^{\mathrm{a}}$ & $23.40^{\mathrm{a}}$ & $22.54^{\mathrm{a}}$ \\
TMA, mg N/100g muscle & $22.64^{\mathrm{a}}$ & $23.42^{\mathrm{a}}$ & $20.47^{\mathrm{a}}$ & $19.88^{\mathrm{a}}$ \\
\hline
\end{tabular}

${ }^{\mathrm{a}}$ Means within a row with different superscripts are different $(p<0.05)$. 
Table 3. Changes in muscle pH, moisture, fat, TBARS, color, cook yield and shear force during storage.

\begin{tabular}{|l|c|c|c|}
\hline \multirow{2}{*}{ Trait } & \multicolumn{3}{|c|}{ Length of storage at $1-2^{\circ} \mathrm{C}$} \\
\cline { 2 - 4 } & 0 & 8 & 15 \\
\hline Muscle pH & $6.30^{\mathrm{a}}$ & $6.32^{\mathrm{a}}$ & $6.22^{\mathrm{a}}$ \\
Moisture, \% & $75.85^{\mathrm{a}}$ & $75.71^{\mathrm{a}}$ & $75.42^{\mathrm{a}}$ \\
Fat, \% & $5.00^{\mathrm{a}}$ & $4.98^{\mathrm{a}}$ & $5.95^{\mathrm{b}}$ \\
TBARS, mg MDA/100g & $0.9^{\mathrm{a}}$ & $0.7^{\mathrm{b}}$ & $0.7^{\mathrm{b}}$ \\
L* value $^{*}$ & $48.13^{\mathrm{a}}$ & $51.14^{\mathrm{b}}$ & $50.18^{\mathrm{b}}$ \\
$\mathrm{a}^{*}$ value & $-1.80^{\mathrm{a}}$ & $-2.38^{\mathrm{a}}$ & $-2.05^{\mathrm{a}}$ \\
$\mathrm{b}^{*}$ value & $4.19^{\mathrm{a}}$ & $9.10^{\mathrm{b}}$ & $8.37^{\mathrm{b}}$ \\
Cook yield, \% & $73.18^{\mathrm{a}}$ & $81.23^{\mathrm{b}}$ & $79.15^{\mathrm{b}}$ \\
Shear force, g/g of sample & $310.84^{\mathrm{a}}$ & $212.91^{\mathrm{a}}$ & $278.79^{\mathrm{a}}$ \\
\hline
\end{tabular}

${ }^{\mathrm{ab}}$ Means within a row with different superscripts are different $(p<0.05)$. 
Table 4. Changes in APC, TVBN, and TMA of fillets during storage.

\begin{tabular}{|l|c|c|c|}
\hline \multirow{2}{*}{ Trait } & \multicolumn{3}{|c|}{ Length of storage at $1-2^{\circ} \mathrm{C}$} \\
\cline { 2 - 4 } & 0 & 8 & 15 \\
\hline APC, $\log _{10} \mathrm{CFU} / \mathrm{cm}^{2}$ & $1.94^{\mathrm{a}}$ & $4.14^{\mathrm{b}}$ & $5.02^{\mathrm{c}}$ \\
TVBN, mg N/100g muscle & $23.44^{\mathrm{a}}$ & $24.69^{\mathrm{a}}$ & $25.22^{\mathrm{a}}$ \\
TMA, mg N/100g muscle & $20.87^{\mathrm{a}}$ & $20.96^{\mathrm{ab}}$ & $22.97^{\mathrm{b}}$ \\
\hline
\end{tabular}

${ }^{a b c}$ Means within a row with different superscripts are different $(p<0.05)$. 
Table 5. Effect of ASC on percent fatty acid* content of fillets.

\begin{tabular}{|l|c|c|c|c|}
\hline \multirow{2}{*}{ Fatty acid } & \multicolumn{4}{|c|}{ Treatment } \\
\cline { 2 - 5 } & Control & Water & $\begin{array}{c}50 \mathrm{ppm} \\
\text { ASC }\end{array}$ & $\begin{array}{c}1000 \mathrm{ppm} \\
\text { ASC }\end{array}$ \\
\hline C14:0 & 3.74 & 3.86 & 3.79 & 3.87 \\
\hline C15:0 & 0.18 & 0.23 & 0.24 & 0.26 \\
\hline C16:0 & 20.71 & 20.90 & 20.72 & 20.66 \\
\hline C16:1 & 17.09 & 16.22 & 17.79 & 18.12 \\
\hline C17:0 & 0.23 & 0.26 & 0.28 & 0.29 \\
\hline C17:1 & 0.12 & 0.17 & 0.21 & 0.14 \\
\hline C18:0 & 3.67 & 3.79 & 3.72 & 3.75 \\
\hline C18:1n9 & 8.57 & 9.48 & 9.36 & 10.33 \\
\hline C18:2n6 & 8.11 & 8.19 & 7.02 & 7.64 \\
\hline C18:3 n3 & 1.18 & 1.32 & 1.19 & 1.15 \\
\hline C18:3 n6 & 0.01 & 0.03 & 0.02 & 0.02 \\
\hline C20:1 & 0.81 & 0.83 & 0.74 & 0.80 \\
\hline C20:2 & 0.66 & 0.68 & 0.73 & 0.78 \\
\hline C20:3 n3 & 0.01 & 0.03 & 0.01 & 0.02 \\
\hline C20:3 n6 & 0.08 & 0.2 & 0.11 & 0.19 \\
\hline C20:4 n6 & 0.63 & 0.60 & 0.50 & 0.56 \\
\hline C20:5 n3 & 10.03 & 9.37 & 8.89 & 9.44 \\
\hline C22:2 & 24.99 & 25.20 & 24.86 & 22.74 \\
\hline C22:2 & 10.03 & 9.37 & 8.88 & 9.44 \\
\hline C22:6 n3 & 24.99 & 25.20 & 24.86 & 22.74 \\
\hline C24:1 & 0.10 & 0.18 & 0.15 & 0.17 \\
\hline sat/unsat & 0.39 & 0.39 & 0.40 & 0.39 \\
\hline w3/w6 & 0.78 & 0.79 & 0.80 & 0.77 \\
\hline
\end{tabular}

No differences were found ( $p>0.05)$.

*Values are relative percent of total fatty acids from three replications. 
Table 6. Changes in percent fatty acid* content during storage.

\begin{tabular}{|l|c|c|c|}
\hline \multirow{2}{*}{ Fatty acids } & \multicolumn{3}{|c|}{ Length of storage at 1-2 ${ }^{\circ} \mathrm{C}$} \\
\cline { 2 - 4 } & 0 & 8 & 15 \\
\hline $\mathrm{C} 14: 0$ & $4.11^{\mathrm{a}}$ & $3.77^{\mathrm{a}}$ & $3.57^{\mathrm{a}}$ \\
\hline $\mathrm{C} 15: 0$ & $0.32^{\mathrm{b}}$ & $0.20^{\mathrm{ab}}$ & $0.16^{\mathrm{a}}$ \\
\hline $\mathrm{C} 16: 0$ & $21.07^{\mathrm{a}}$ & $20.43^{\mathrm{a}}$ & $20.72^{\mathrm{a}}$ \\
\hline $\mathrm{C} 16: 1$ & $17.92^{\mathrm{a}}$ & $17.96^{\mathrm{a}}$ & $16.03^{\mathrm{a}}$ \\
\hline $\mathrm{C} 17: 0$ & $0.36^{\mathrm{a}}$ & $0.23^{\mathrm{a}}$ & $0.19^{\mathrm{a}}$ \\
\hline $\mathrm{C} 17: 1$ & $0.15^{\mathrm{a}}$ & $0.16^{\mathrm{a}}$ & $0.17^{\mathrm{a}}$ \\
\hline $\mathrm{C} 18: 0$ & $3.93^{\mathrm{a}}$ & $3.60^{\mathrm{a}}$ & $3.66^{\mathrm{a}}$ \\
\hline $\mathrm{C} 18: 1 \mathrm{n} 9$ & $12.26^{\mathrm{a}}$ & $10.06^{\mathrm{a}}$ & $6.18^{\mathrm{a}}$ \\
\hline $\mathrm{C} 18: 2 \mathrm{n} 6$ & $7.04^{\mathrm{a}}$ & $7.23^{\mathrm{a}}$ & $8.99^{\mathrm{a}}$ \\
\hline $\mathrm{C} 18: 3 \mathrm{n} 3$ & $1.35^{\mathrm{a}}$ & $1.18^{\mathrm{a}}$ & $1.10^{\mathrm{a}}$ \\
\hline $\mathrm{C} 18: 3 \mathrm{n} 6$ & $0.05^{\mathrm{a}}$ & $0.02^{\mathrm{a}}$ & $0.01^{\mathrm{a}}$ \\
\hline $\mathrm{C} 20: 0$ & $0.03^{\mathrm{a}}$ & $0.43^{\mathrm{a}}$ & $0.01^{\mathrm{a}}$ \\
\hline $\mathrm{C} 20: 1$ & $0.83^{\mathrm{a}}$ & $0.76^{\mathrm{a}}$ & $0.79^{\mathrm{a}}$ \\
\hline $\mathrm{C} 20: 2$ & $0.93^{\mathrm{b}}$ & $0.67^{\mathrm{ab}}$ & $0.55^{\mathrm{a}}$ \\
\hline $\mathrm{C} 20: 3 \mathrm{n} 3$ & $0.20^{\mathrm{a}}$ & $0.01^{\mathrm{a}}$ & $0.03^{\mathrm{a}}$ \\
\hline $\mathrm{C} 20: 3 \mathrm{n} 6$ & $0.22^{\mathrm{a}}$ & $0.12^{\mathrm{a}}$ & $0.09^{\mathrm{a}}$ \\
\hline $\mathrm{C} 20: 4 \mathrm{n} 6$ & $0.51^{\mathrm{a}}$ & $0.61^{\mathrm{a}}$ & $0.61^{\mathrm{a}}$ \\
\hline $\mathrm{C} 20: 5 \mathrm{n} 3$ & $9.53^{\mathrm{a}}$ & $8.37^{\mathrm{a}}$ & $10.40^{\mathrm{a}}$ \\
\hline $\mathrm{C} 22: 2$ & $0.89^{\mathrm{a}}$ & $0.90^{\mathrm{a}}$ & $0.86^{\mathrm{a}}$ \\
\hline $\mathrm{C} 22: 6 \mathrm{n} 3$ & $24.15^{\mathrm{a}}$ & $23.14^{\mathrm{a}}$ & $26.05^{\mathrm{a}}$ \\
\hline $\mathrm{C} 24: 1$ & $0.19^{\mathrm{a}}$ & $0.13^{\mathrm{a}}$ & $0.13^{\mathrm{a}}$ \\
\hline sat/unsat & $0.38^{\mathrm{a}}$ & $0.39^{\mathrm{a}}$ & $0.40^{\mathrm{a}}$ \\
\hline w3/w6 & $0.80^{\mathrm{a}}$ & $0.77^{\mathrm{a}}$ & $0.78^{\mathrm{a}}$ \\
\hline
\end{tabular}

${ }^{a b c}$ Means within each row with different superscripts are different $(p<0.05)$.

*Values are relative percent of total fatty acids from three replications. 


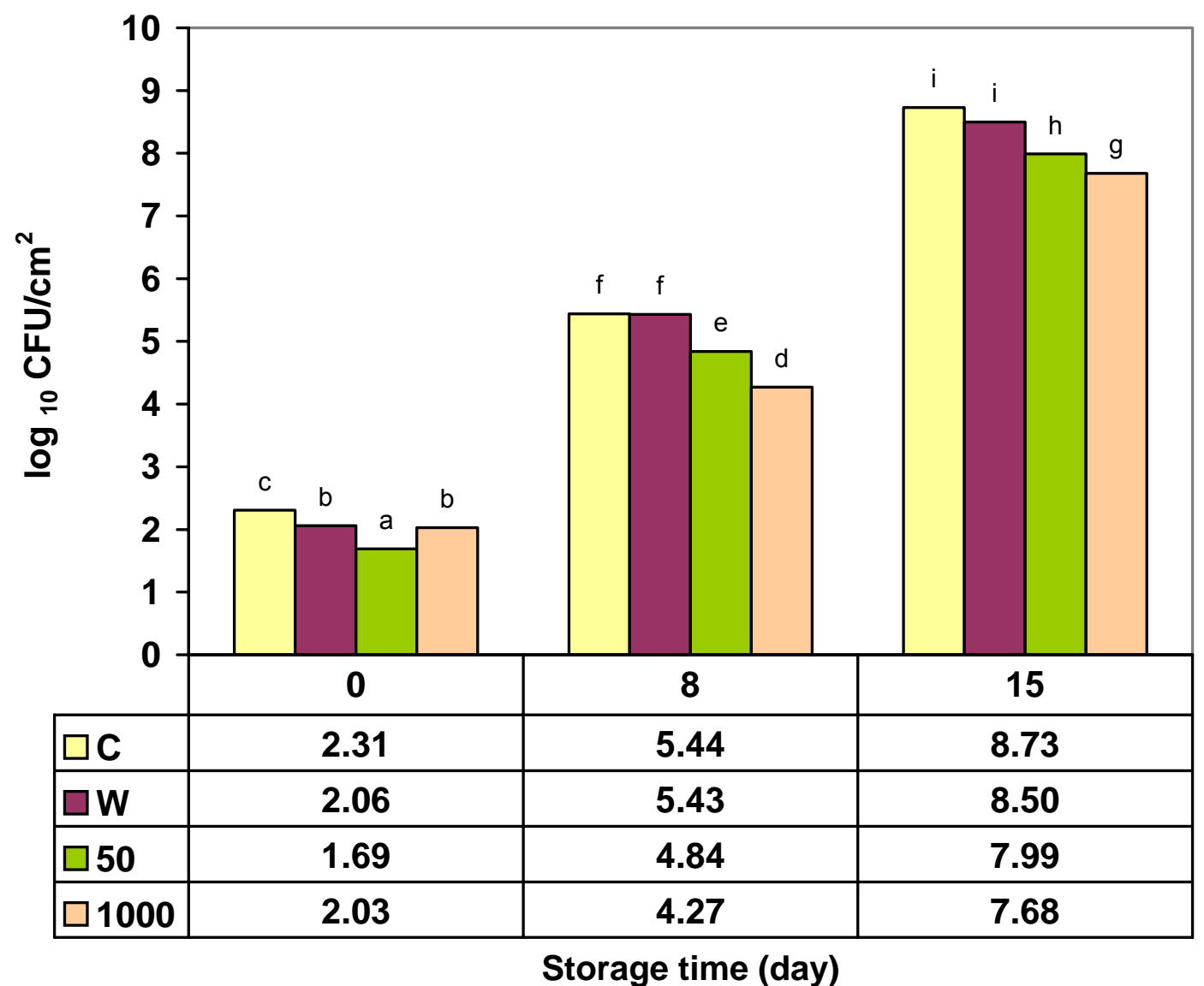

Figure 1. Effect of ASC and storage time on psychrotrophic counts.

abcdefghi Bars with different superscripts are different $(p<0.05)$. 


\section{APPENDICES}




\section{APPENDIX 1}

\section{Muscle Lipid Extraction and Fatty Acid Methylation (Also use for feed sample with animal base)}

\section{Sample preparation}

Sample can be stored by either one of these methods:

1. Intact muscle form. Fillets (excluding belly flap) are skinned, vacuum packed and kept at $-20^{\circ} \mathrm{C}$. When lipid extraction is performed, frozen fillets are partially thawed and processed the same as powdered sample preparation.

2. Powder form. Fillets are skinned, cut into small pieces (excluding belly flap), frozen with liquid $\mathrm{N}_{2}$, and powdered in a Waring blender for 2-3 min. BHT is added before blending to prevent fat oxidation. Powdered samples are kept in screw cap plastic tubes at $-80^{\circ} \mathrm{C}$.

\section{Instruments}

1. Waring blender and liquid nitrogen

2. Hood

3. $60^{\circ} \mathrm{C}$ water bath

4. $90^{\circ} \mathrm{C}$ water bath or heating block

5. Manifold and nitrogen gas

6. Centrifuge

7. Vortex

\section{Chemicals}

1. Trizma/EDTA buffer:

50 mM Trizma HCl: 7.880 g per 1000 mL dd water $1 \mathrm{mM}$ EDTA-disodium salt: $0.372 \mathrm{~g}$ per $1000 \mathrm{~mL}$ dd water Mix above stock solutions, adjust $\mathrm{pH}$ to 7.4 with $5 \mathrm{~N}$ then $1 \mathrm{~N} \mathrm{NaOH}$, then filter using a 0.2 micron filter storage unit. Buffer is stored at $4^{\circ} \mathrm{C}$. 
2. C:M:A (chloroform:absolute methanol: glacial acetic acid $-2: 1: 0.015$ by volume) e.g. 400:200:3 mL (use glass cylinder)

3. $2: 1$ (chloroform:methanol by volume) e.g. $400: 200 \mathrm{~mL}$ (use glass cylinder)

4. $4: 1$ (chloroform:methanol by volume) e.g. $400: 100 \mathrm{~mL}$ (use glass cylinder)

5. $4 \%(w / v) \mathrm{H}_{2} \mathrm{SO}_{4}$ in anhydrous methanol. prepare fresh. Do not keep the left-over solution

6. Chloroform

7. Anhydrous $\mathrm{Na}_{2} \mathrm{SO}_{4}$

8. 1-PS Phase separation filters (diameter $9 \mathrm{~cm}$ ). This filter type takes water out off solution, thus filtered solution is water free.

9. Glasswool

\section{Lipid extraction step}

1. Weigh $0.5 \mathrm{~g}$ powdered sample $+5 \mathrm{~mL}$ Trizma/EDTA (use plastic pipett) in 50-mL screw cap plastic tube.

2. Vortex for $60 \mathrm{sec}$.

3. Transfer $5 \mathrm{~mL}$ of homogenate in $50-\mathrm{mL}$ Teflon lined screw cap glass tube, add 5 $\mathrm{mL}$ Trizma/EDTA and $40 \mathrm{~mL}$ C:M:A (use glass cylinder).

4. Vortex vigorously twice $(15 \sec \times 2)$.

5. Hold at room temperature for $10 \mathrm{~min}$.

6. Centrifuge at $900 \mathrm{~g}(4000 \mathrm{rpm}), 10^{\circ} \mathrm{C}$ for $10 \mathrm{~min}$.

7. Transfer all lower layer with glass Pasteur pipet over 1-PS filter. Collect filtered sample in 50-mL Teflon lined screw cap glass tube. (Pre-rinse filter paper 3 times with $5 \mathrm{~mL}$ 2:1 C:M each (use glass cylinder) to remove trace silicone residue, and put away filtrate.)

8. Add $25 \mathrm{~mL} 4: 1 \mathrm{C}: \mathrm{M}$ (use glass cylinder) to the upper layer, vortex for $15 \mathrm{sec}$, and centrifuge at $900 \mathrm{~g}(4000 \mathrm{rpm}), 10^{\circ} \mathrm{C}$ for $10 \mathrm{~min}$.

9. Again transfer all lower layer over 1-PS filter. Rinse filter paper with $5 \mathrm{~mL} 2: 1 \mathrm{C}: \mathrm{M}$ after the filtrate has gone. (Filtrated sample can be stored at $0-5^{\circ} \mathrm{C}$ for $1-3$ days.)

10. Blow down under regular nitrogen gas (to dry sample) in $60^{\circ} \mathrm{C}$ water bath.

Nitrogen gas outlet should be close to liquid surface. Temperature must not be 
higher than $60^{\circ} \mathrm{C}$. Set hot plate at 4 . When temperature goes to $55^{\circ} \mathrm{C}$, set it back to 2. Watch Temperature Often.

\section{Methylation step}

11. Add $4 \mathrm{~mL}$ of $4 \% \mathrm{H}_{2} \mathrm{SO}_{4}$ solution (use glass pipett). (cap thightly-no leaking)

12. Heat in water bath or heating block at $90^{\circ} \mathrm{C}$ for $60 \mathrm{~min}$. Set water bath at $100^{\circ} \mathrm{C}$, cover with foil.

13. Cool to room temperature then add $3 \mathrm{~mL}$ dd water (to stop reaction).

14. Add $8 \mathrm{~mL}$ chloroform (use glass pipett), then vortex for $30 \mathrm{sec}$.

15. Centrifuge at $900 \mathrm{~g}(4000 \mathrm{rpm}), 10^{\circ} \mathrm{C}$ for $10 \mathrm{~min}$.

16. Transfer the bottom layer (chloroform layer) through a $\mathrm{Na}_{2} \mathrm{SO}_{4}$ filled glass Pasteur pipet into 50-mL Teflon lined screw cap glass tube. (Fill Pasteur pipet with glass wool first, then with around 1 inch of $\mathrm{Na}_{2} \mathrm{SO}_{4}$ layer.)

17. Blow down under nitrogen gas in $60^{\circ} \mathrm{C}$ water bath. Nitrogen gas outlet should be close to liquid surface (same as \#10).

18. Resuspend dried sample in $3 \mathrm{~mL}$ of isooctane and keep at $-20^{\circ} \mathrm{C}$ or inject into GC. 


\section{APPENDIX 2}

\section{Procedure to determine sodium chlorite concentration of ASC solution}

1. Weigh $25-30 \mathrm{~g}$ of ASC solution into a teated $250 \mathrm{~mL}$ beaker. Record weight to the nearest $0.01 \mathrm{~g}$.

2. Dilute sample with $100 \mathrm{~mL}$ of deionized distilled water.

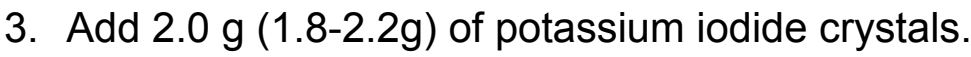

4. Add stir bar, and mix until crystals dissolve.

5. Add $10 \mathrm{~mL}$ of hydrochloric acid sol. N/2(Red/brown color appears)

6. While stirring, titrate with sodium thiosulphate N/10 until brown color fades to pale yellow.

7. Add $2 \mathrm{~mL}$ of starch indicator, $0.5 \%$

8. Continue titration with sodium thiosulphate N/10 to a clear end point

9. Record volume of sodium thiosulphate used in $\mathrm{mL}(\mathrm{V})$ to the nearest $0.01 \mathrm{~mL}$. 10. Calculation: $(V) \times 2261 /$ Sample $w t=p p m ~ \mathrm{NaClO}_{2}$ 


\section{APPENDIX 3}

\section{Statistical program for all responses}

option LS=80 pagesize $=\mathbf{6 0}$ nonumber;

title ;

data; input block day treat $\$$ response;

cards;

proc print;

proc $\mathbf{g l m}$; classes treat block day; model response=block treat|day block(treat); test $\mathrm{H}=$ treat $\mathrm{E}=$ block(treat);

Ismeans treat/pdiff $E=$ block(treat);

Ismeans day treat ${ }^{*}$ day/pdiff;

proc sort; by treat;

proc means mean stderr; by treat;

proc sort; by day;

proc means mean stderr; by day;

proc sort; by treat day;

proc means mean stderr; by treat day;

run; 


\section{CURRICULUM VITAE}

Parents Hanumareddy Bareddy

Leelavathi Bareddy

Date of Birth $\quad$ August 29, 1976

Schools Attended Acharya N.G. Ranga Agricultural university

Tamil Nadu Agricultural University

West Virginia University

Degrees Conferred Bachelor of Science 1997

Master of Science in Food Science and Nutrition 2000

Master of Science in Animal and Veterinary Sciences 2003 